\title{
INDONESISCHE LASVORMEN.
}

DOOR

J. GONDA.

Het grootste deel van de inhoud van een grammatika van een Indonesische taal pleegt te zijn gewijd aan een opsomming van de prae- en suffixen, indien aanwezig ook infixen, hun vorm, de betekenisklassen der ermee gevormde woorden en het gebruik daarvan in de zin. Het begrip affix, dat inderdaad in de Archipel-talen belangrijk is, schijnt de geesten van vele spraakkunstschrijvers dermate te boeien, dat zij geneigd zijn aan te nemen, en veelal ook niet aarzelen neer te schrijven, dat telkenmale wanneer een van twee in klank grotendeels overeenstemmende en in betekenis hetzij identieke, hetzij verwante woorden een klank of een klankgroep meer heeft dan de andere, dat meerdere een affix vertegenwoordigt. En is zo'n affix dan in de levende taal in andere woorden niet of slechts met moeite aan te treffen, of wel is er geen min of meer omlijnde betekenis (functie) aan toe te kennen, of wel meent men al dan niet terecht, dat er geen nieuwe woorden meer mee ontstaan, dan spreekt men van verstarde affixen.

Het is nauwelijks nodig citaten te geven om het hier gezegde te staven. „Meerlettergrepige woorden welke niet tot eenvoudigen vorm kunnen teruggebracht worden, bevatten wel steeds een thans in onbruik geraakt afleidingselement....", zegt bv. Jonker ${ }^{1}$ ). Ten aanzien van Maleise uitdrukkingen als tali-těmali, ,allerlei touwwerk, het gezamenlijke touwwerk van een schip”, turun-těmurun ,van geslacht tot geslacht”, gěmilan of gumilain „blinkend”, gěmilap of gumilap ,schitterend”, gěmuruh of gumuruh „donderend” heerst er, dat kan men wel zeggen, bijkans een communis opinio, dat zij het infix -umbevatten. Voor Dempwolff ${ }^{2}$ ) staat het vast, dat tag. balaná' naast bañá ,kruik" het infix -al- bevat, dat we in jav. krapyak „knetteren” (vgl. tag. kapak ,het geluid van slaan”, jav. kampak ,grote bijl”) twee

1) J. C. G. Jonker, Rottineesche spraakkunst (1915), § 6, p. 8.

2) O. Dempwolff, Vergleichende Lautlehre des austronesischen Wortschatzes II (1937), p. 8.

Downloaded from Brill.com04/26/2023 11:25:53AM

D1. 102. 
infixen, $r$ en $y$, moeten zien ${ }^{1}$ ), dat in tag. kulubot ,vorm" (naast $k u b o t$, rimpel, plooi”) een infix $-u l$ - steekt ${ }^{2}$ ), etc. Op overeenkomstige wijze ziet men in de $l$ van jav. gligik, ,ginnegappen” naast $\dot{n}$ gigik ,giechelen" een infix, in $j \breve{e}-$ van $j \breve{g} g i g i k$,giechelen” een praefix. In een zeer recent $\operatorname{artikel}^{3}$ ) blijft ook R. A. Kern voortdurend van infixen en andere affixen als enige woorduitbreidende elementen spreken.

M.i. doet men echter goed te onderscheiden. Wanneer we stellen varianten van klaarblijkelijk hetzelfde woord vinden, zodat het ene lid van zo'n stel een klank of syllabe langer is dan het andere (of : dan de andere), zonder dat het langere woord een andere waarde; betekenis, functie en zonder dat het uitbreidende element in een groep gelijksoortige woorden éénzelfde definiëerbare functie heeft, zou ik dit element zeker geen affix noemen: men noemt ook -ed-in vlaams pledompen $=$ plompen geen affix, evenmin als de $m$ in ned. pampier naast papier. Ook die woorduitbreidende elementen, die een verandering in gevoelswaarde, een zekere intensivering van een in een woord liggend affectief begrip met zich meebrengen, die onomatopeeën en klank-symbolische woorden meer adaequaat maken aan de indruk, die de er door weergegeven voorstelling wekt, zou ik zo niet betitelen: ook ink in ned. rinkinken naast rinkelen, evenmin als de $r$ in ned. brullen tgr. mned. bullen ,tieren, razen”. Een Indonesisch affix is niet hetzelfde als een Indogermaans, doch in de definitie dient te worden opgenomen, dat het op systematische wijze derivaten vormt van een grondwoord ${ }^{4}$ ), dat het een wel te omschrijven, in een taal hetzij nu, hetzij vroeger (in dat geval is het verstard, als de $t$ in ned. dorst, vorst, list) levende grammatikale functie heeft (het brengt tot een bepaalde ,woordsoort" of woordkategorie, draagt een zelfde betekenisnuancering ten opzichte van de betekenis van het grond-

1) Ibidem, III, p. 74.

2) Ibidem, III, p. 77.

3) R. A. Kern, Wortels en grondwoorden in de Austronesische talen, Bijdr. 102 , p. 275 vlg. Vgl. ook K. Wulff, Uber das Verhältnis des Mal.-Pol. zum Indochin. (Danske Vid. Selsk. 27, 2; 1942), p. 45 vlg.; 80 vlgg., waarbij reeds mijn opmerkingen in Museum 50 (1942), 24.

$\left.{ }^{4}\right)$ Dit kan ook éénsyllabig zijn en dus in gedaante met de wortel samenvallen. Ten onrechte houdt R. A. Kern, t.a.p. (in afwijking van Brandstetter) dit niet in het oog: linud p. 293 is geen voorbeeld van ,infigering” van -inin een wortel, maar een van infigering van -in- in een eensyllabig grondwoord: dat lud grondwoord is, blijkt uit lumud, luděn, anilud etc., en uit het zelfstandige gebruik van lud. Men verklaart toch ook de Nederlandse imperatief drink niet tot een wortel, al valt hij in gedaante samen met een vorm van de wortel die in drinken, dronk, drank, gedronken steekt? 
woord, speelt een bepaalde syntaktische rol, het komt in een aantal woorden van dezelfde kategorie op overeenkomstige wijze voor).

Of al degenen die ten aanzien van de hierboven genoemde en dergelijke elementen de termen ,infix” etc. bezigen, er werkelijk volkomen van overtuigd zijn, dat die elementen geheel van dezelfde aard zijn (althans waren) als těr - in mal. těr-sĕpuh ,donker gekleurd”, -an in rambut-an ,een soort vrucht met haarachtige schil”, -in- in ojav. tiněpak, zg. passief bij těpak ,met de hand slaan”, is een vraag, die we hier maar zullen laten rusten. Men doet echter alsof, men houdt alle elementen, die een woord meer heeft dan in klank overeenstemmende en in betekenis samenbehorende woorden voor affixen, voor in wezen gelijk aan genoemde těr-, -an, -in- etc. En men trekt uit die veronderstelde identiteit van soort o.a. de conclusie, dat zo'n als affix beschouwd element, indien het in vorm overeenstemt met een werkelijk affix in een verwante taal, eens dezelfde functie gehad moet hebben als dat werkelijke affix. Men verklaart bv. op grond van vergelijking van het Javaanse infix -um- Maleise woorden als gěmuruh, gěmilan, (turun-) tumurun, (tali-) těmali tot „oude activa of aoristen of incohativa”; „oude”, d.w.z. oorspronkelijk waren ze dat, doch nu zijn ze verstard ${ }^{1}$ ).

Maar over die verstarring heersen soms weer zonderlinge denkbeelden. Spat ${ }^{2}$ ) bv. leert naar aanleiding van mal. pělatuk ,specht” bij patuk ,pikken van (vogels)”, gěrigi ,getand” bij gigi ,,tand” en klanknabootsende woorden als gěrěsak, gěrědum etc., dat hierin de invoegsels - ̌̌l-, $\breve{e r}$ - steken en voorts, dàt ,,de meeste afleidingen met een invoegsel in het Maleisch zeer nabij de versteende afleidingen (komen), en dus vrijwel als grondwoorden te beschouwen (zijn)". Onder versteende of verstarde vormen verstaat men niet ten ondergegane, nog gebruikte resten van eens levende (d.i. nog nieuwe vormen producerende) vormkategorieën, die in een later stadium van de taal, in het dan bestaande systeem niet als behorende tot een levende vormkategorie worden gevoeld; boven noemden we al het versteende suffix $-t$ in het Nederlands: er worden geen nieuwe substantieven van dat type meer gevormd. Maar in een vroegere periode der taal was dat wel het geval, toen was het procédé om bepaalde naamwoorden, nomina actionis, met idg. $-t i->$ germ. $-t$ - (got. gif- $t-s$ ) te vormen levend, toen was het productief. Wanneer dus Spat in de

د) Zie ook Bijdr. 99, p. 433 .

2) C. Spat, Maleische Taal, Overzicht van de Grammatica (1920), p. 36, §33. 
aanhef van dezelfde paragraaf, waaruit ik juist citeerde, zegt, dat „de invoegsels in het Maleisch weinig tot ontwikkeling (zijn) gekomen", betoogt hij daarmee iets geheel anders dan in het verdere deel van de paragraaf: stel dat -ěl- in pělatuk etc. slechts resten vertegenwoordigen van een vroeger levend infix, dan mogen we wel zeggen, dat er vroeger meer vormen met -ěl- geweest zullen zijn, maar in hoeverre die formatie eens tot ontwikkeling is gekomen is veel moeilijker uit te maken. Bedoelt Spat echter met de aanhef ,weinig tot ontwikkeling gekomen", dat er niet meer vormen van in het aanzijn zijn gekomen dan de thans bestaande, dan behoeft dat niet te impliceren, dat de formaties verstard zijn in de gebruikelijke zin des woords. En gaat men de klanknabootsende en daarmee in vorm overeenkomende woorden van de typen gěrěsak, gěměrěncun ${ }^{1}$ ) en dergelijke, die Spat ook in deze paragraaf behandelt, na, dan blijkt ten eerste hun aantal verre van beperkt te zijn en ten tweede hun vormingsprocédés juist in de levende taal nog productief.

Met het gesignaleerde streven ieder ,element meer” voor een affix te houden gaat vaak samen de opvatting - we wezen er al op -, dat in klank overeenstemmende elementen ook in wezen identiek zijn. „Drie- en meerlettergrepige grondwoorden” zegt weer Spat ${ }^{2}$ ), „hebben dikwijls de gedaante van een afgeleid woord. Dit is inzonderheid het geval met vele namen van voortbrengselen uit het plantenen uit het dierenrijk. Oorspronkelijk waren zij afgeleide woorden; thans zoude men ze versteende afleidingen kunnen noemen. $\mathrm{Zij}$ bewijzen door hun vorm ook, dat in een vroegere periode voorvoegsels in gebruik zijn geweest, welke men thans niet meer kent". Hij somt dan een aantal trisyllaba die met $m \breve{e}$ - beginnen op, evenzo een aantal met $p \breve{e}-$, $t \breve{e}-, k \breve{e}-$, s $\breve{e}^{-}$. Dat hij in de aanhef veel meer zegt dan hij verantwoorden kan, laten we rusten; tegen een formulering als ,de volgende vormen, die uiterlijk de gedaante toonen van een $b \breve{e}$-vorm; bĕdukuin, bĕlanak etc." kan men weinig bezwaar maken, een zin als ,woorden...., die oudtijds werden afgeleid, doch thans als grondwoorden zijn te beschouwen, gevormd met een praefix $d i$ - zijn er niet" verraadt echter, dat de auteur meent te mogen verwachten, dat alle thans bestaande affixen in de bedoelde ,versteende afleidingen" terugkeren.

1) Zie mijn Remarks on onomatopoeia, sound-symbolism and wordformation etc., T. B. G. 80 (1940), p. 133 vlgg., speciaal p. 204.

2) O.c., p. $30, \S 27$. 
Anderen ${ }^{1}$ ) zijn zo ver gegaan, dat zij uitdrukkelijk tĕr- in mal. těrsĕnyum ,glimlachen”, těrkějut „,schrikken” etc. identificeren met těr - in těrban் „vliegen”, těrjun ,afspringen” etc., en op dezelfde wijze andere praefixen in oorsprong gelijk stellen aan in klank gelijke eerste syllaben van grondwoorden. Bewezen, dat men tot deze identificaties het recht heeft, heeft nog niemand. En zolang dat niet geschied is, is het methodisch juister geen identiteit aan te nemen. Gaat men de geschiedenis van het leerstuk na, dan blijkt dat door de èerste beoefenaars der Vergelijkende Indonesische Taalwetenschap uit de Indogermanistiek in haar eerste periode overgenomen te zijn, waar men een eeuw geleden ook zonder op de bezwaren te letten tot dergelijke gelijkstellingen van in klank identieke of overeenkomende formele elementen (alsook tot hun identiteit met afzonderlijke woordjes, pronomina, praeposities etc.) overging.

Reeds bij vorige gelegenheden heb ik twijfel uitgesproken aan de

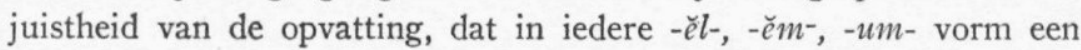
infix (d.w.z. een van een grondwoord op systematische aan regels gebonden wijze een afleiding vormend element) zal moeten worden gezien. In verband met de verklaring van vormen met inwendige nasaal in Dajaks en andere Indonesische talen wees ik $\mathrm{er}^{2}$ ) op, dat al wat er in een woord, vergeleken met blijkbaar verwante woorden, als formatief of afleidingen-vormend element ${ }^{3}$ ) uitziet, dat in oorsprong niet behoeft te wezen. Zelfs al zou het Nederlandse taalgevoel -uw- in zwaluw, schaduw, zenuw als een suffix opvatten, toch is dit element, dat in deze woorden, vergeleken met du. Schwalbe, eng. shade, ned. zeen etc. de indruk wekt een suffix te zijn, van geheel andere oorsprong ${ }^{4}$ ). Elders ${ }^{5}$ ) besprak ik o.a. het element $-u m$-, dat ook in het Oud-Javaans, waar het zonder enige twijfel in een groot aantal vormen als infix (praefix) optreedt, vaak in klanknabootsende en soortgelijke woorden voorkomt: kumĕcěk, kuměñar, kumĕtĕg. In een aantal gevallen schijnt $u m$ een emfatische of intensiverende waarde te hebben (kumětug, gumĕnterr), in onomatopeeën die betekenen ,donderen, dreunen, rommelen etc." schijnt het deel te hebben aan het nabootsen van de klank. Ik kwam daar tot de vraag, of dit

\footnotetext{
1) Zeer onlangs weer R. A. Kern, Bijdr. 102, p. 287.

2) Bijdr. 101, p. 149 vlg.

3) Een formatief element of formans vormt grondwoorden „uit" wortels, een afleidend element (derivatief) afleidingen „uit" grondwoorden.

4) Zie aldaar, p. 151

5) T. B. G. 80 , p. 203 , zie ook vanaf p. 196.
} 
-um- niet te onderscheiden is van het grammatikale -um- in umadĕg naast maíadĕg ,staan”, een vraag die ik later voor dergelijke formaties bevestigend beantwoordde ${ }^{1}$ ): gěměru- in mal. gĕmĕrucuk ,to vibrate dully" is m.i. geen derivatief of combinatie van derivatieven, maar een formatief element ${ }^{2}$ ); de $r$-combbinaties (-е̌r $r$-, -ar-, $-u r$ - etc.) in woorden, die geluiden, snelle bewegingen etc. aangeven als oudjav. karape, karutuk, kĕrěcěk, garantun, gěrĕmus, taritis, gurilip etc. zijn eveneens bij de woordvorming, niet onder de woordafleiding te behandelen ${ }^{3}$ ); onder de vele woorden met inwendige nasaal of liquida zij er m.i. talrijke, waarin deze klank niet een gereduceerd infix vertegenwoordigt ${ }^{4}$ ).

In aansluiting aan de bespreking van deze formaties ga ik thans over tot een beschouwing van enkele andere verwante typen.

Gaan we in de eerste plaats na welke woorden met -е̌m- en eventueel andere combinaties van consonant en $m$ er in enkele Indonesische talen, die geen levend afleidingselement (infix) -um-, -е̌m- kennen, in hoofdzaak en afgezien van de voorlopig onverklaarbare namen van planten en dergelijke voorkomen. Ten eerste in het Maleis ${ }^{5}$ ): cĕmampin ,in flarden" = compain-campin, campan-campin ,uitgerafeld, in flarden"; cěmemis ,vuil (adj.) om de mond na het eten" (Singapore) naast cěmomot ,vuil (adj.) om de mond na het eten”, cĕmuas etc.; cĕmĕrlain „straling, glansrijk”, naast cĕrlan „stralend van licht”, cělon்-cělain ,het flikkeren”; cĕmabai ,rafelig aan de randen" = jera $(m) b a i$; cĕmĕrlin ,flikkerend”; cĕmon̈kah-cĕmaìkeh „verward aan alle kanten uitstekend" naast coikkah ,uitstekend”, conkah-cankeh ,zeer ongelijk”; cěmidu „zenuwachtig”; gěmalai, gumalai naast kěmalai, (Kĕdah) gěmoìlai en lěmah $g$. „,buigzaam”; gĕmalan „overdwars, scheef” naast gala ’ „dwarsboom etc., dwarsbomend”; gěmampai் „,van weinig belang” (volgens Wilkinson leenwoord uit het Javaans) naast gampai் ,id., gemakkelijk”; gěměntam „voortdurend stampen” (onomatopee); gĕmĕ(n)tar, gumĕtar „,bevend” naast gěntar, kĕtar, gělětar „idem”; gěměrlap „fonkelen” naast gĕrlap „flikkering”; gěmilan், gumilà „,refulgent splendour”, a freq(uentative) of gilan ,lustre, glow” (Wilkinson), gilan-gěmilan;

1) Bijdr. 99, p. 397 vlg.; 101, p. 141 vlg.

2) T. B. G. 80 , p. 204.

3) Ibidem, p. 200.

4) Bijdr. 101, p. 141 vlg.

$\left.{ }^{5}\right)$ Men mag aannemen, dat er meer zijn dan de woordenboeken vermelden. Dat sommige dezer woorden ook in verwante talen voorkomen pleit voor hun ouderdom. 
gěmilap „,flikkeren etc.” naast gilap, girlap ,stralend etc.”; gěmirap ,laten trillen, in trilling houden" naast girap "quickening (of the heartbeats); quickening the stroke when rowing or paddling" (Wilkinson) ; gěmulun ,,in kronkelingen, rollen, rond vouwen of plooien" naast gulon ,oprollen; rol”, gulun்-gěmulun ,in rollen of kronkels”, gĕmunci ,water-kruik" naast guci; gěmuruh, gumuruh „rollen (van de donder), een lang donderend geluid maken" naast guruh „donder”; gĕndĕran் „trom”1) : gĕndan் „,idem”; humuron (W. Sumatra, opgave van Von Dewall) ,grazen”; jĕmarai ,,slap neerhangend, van takjes, lange lichamen", in Kedah in jërai-jěmarai, in Selangor in arai-jĕmarai, vgl. bĕrjurai-jurai ,in franjes, kwasten en derg. neerhangen”; jĕmazwa ,verwaand(heid), een belachelijke dunk van zichzelf (hebbend)"; jĕmĕraì (Trengganoe) = sĕbĕran „over de rivier”;

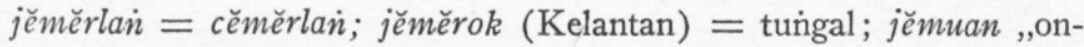
verbeterlijk-misdadig”, jĕmuas ,besmeurd, vuil (van gezicht)”; jĕmuju „karwei-zaad”; kĕmamam (Kedah, Perak) „verkleumd (van handen en voeten na ziekte)"; kěmamar (Perak) „duizelig en knip-

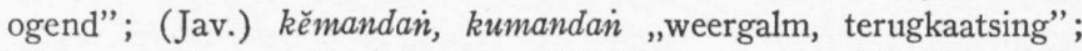
kěmarau „droogte (regenloos weer)”; kěmarok ,geweldige honger”; kĕmatu „steenachtig, hard”, vgl. batu „steen”; kěmawan in awankĕmawan „sfeer der wolken, cumulus-wolken”; kĕmayoh (minder gewoon voor) pěrayoh ,pagaai”, af te leiden van kayoh, vgl. bĕrkayoh; kĕmĕlut „,crisis (in bepaalde ziekten)"; kĕměndit ,gordel” $=k \breve{e}(n)$ dit, gěndit; kěmĕntam ,stampen of trappelen door velen tegelijk" (onom.) ; kĕmĕra (Kedah) ,wanordelijke vlucht” = kěmběra, (Kelantan) cĕměra etc.; kĕmĕrin ,weer-tijger" ${ }^{2}$ ); kĕměrok, kĕmurok (Penang) ,bedorven, ten dele uitgebroed ei”; kĕmetut ,,in de groei belemmerd (speciaal van vruchten die hun grootte niet bereiken)": dial. kĕrěntut, kĕrĕntat, kĕrĕncat, cěntut, bĕncat, tĕrgĕncat, rĕncat, tĕrincat; kĕmilap „,flikkerend”, vgl. kilap, gilap, kĕrlap, kilau, kilat; kĕmirau (Pahang) „hard, half-rijp” = kérau (Kedah); kěmuncak „piek”, (Kedah) kěmocak, pocak, uncak, vgl. koncak ,top”, waarnaast puncak ,top": min. pamuncak; kĕmudi „roer (schip), kruis (van paard)”, vgl. udi (Java) ,achter”, kěmudian ,vervolgens”; kěmukut, lěmukut, mĕlukut, dĕmukut, lukut „doppen, kaf”; kĕmunikus „,ver uitgebroed en bedorven ei"; kumañi ,sexuele impotentie" = kĕdi,

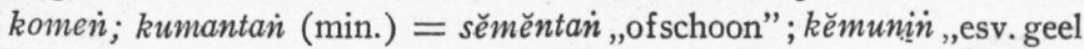

1) Volgens H. C. Klinkert, Woordenboek, s.v. „frequ. van gěndang”?

2) „Etym., orañ Kĕmberriñ: man from the K. district of Ulu Palembang where the inhabitants are reputed to be able to transform themselves into tigers." 
hout”: kumiñ ,,geel”; lěmuas „,besmeurd (gezicht”); lěmun்sir ,vlees van de schouder" = (min.) lěmbusir; měmilis ,voorhoofdsband”; pameo ,proverbial saying”, = buah mulut sindiran; pěmalam ,to fill an interstice by pushing cloth into it with a knife"1) ; permalan (W. Sum.) ,duizelig worden”; pěmalap ,een lamp minder doen schijnen”; pěmali „taboe”; pěmancar ,het bij het tweede of latere uitpersen verkregen kokossap”; pěmankat ,een scheepstype”; pĕmara „tweede afdeling van een grote visfuik" (Malakka), misschien pěmatah „oud gezegde, adat-spreuk", vgl. pěpatah, pěpatahan ,adat-spreuk” en patah „,hulptelwoord voor gezegden, spreekwoorden etc.”; pěměndak ,an ornamental cup-like ring... covering the base of the krishandle"; pц̌menikul „zekere onderdelen van een visfuik"; pěmin̈gak ,heup” bij

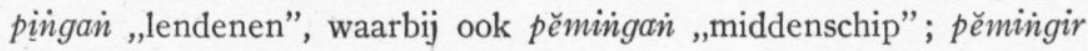
„grensgebied” bij pinggir „rand, grens”; pĕmirah (Perak) „schuchter”; pĕmuntal (Patani) „hoofddoek”; pěmuras „donderbus”; en mogelijk nog enige met $p$ beginnende; sĕmalah in de uitdrukking orai sudra $s$. ,an outcast vagabond”, ,from salah?” (Wilkinson); sĕmampai "loosely lashed together and therefore swaying", naast sampai ,loshangend”, ampai „loshangend en waaiend”, sělampai „(de ceremoniële schouderdoek) zo dragen dat hij aan weerszijden afhangt"; sěmanah „mooi”; sěmanat, sumanat „levensgeest”; sěmayam „op een troon zittend”; sěmějak, sĕmĕnjak ,sedert” = sějak, sĕnjak; sĕmemeh ,bevuild, vuil (adj.) om de mond”; sěměna in tidak s. „losbandig”; bĕrsěmĕnda ,in de familie van zijn vrouw trouwen”; š̆měndal „mika”; sěměnder „boegspriet”; sěmĕntan, sumantan் „ofschoon”; sĕměntara „ondertussen, gedurende" naast sĕntara (Sumatra), antara, min. ook samantara; sěměntĕlah $=$ sětělah „,nadat”; sĕměnton் „stompzinnig”; sĕmĕrbak of sĕmĕrbok „doordringend (van geur), zich verspreiden"; (sěmĕrep, sěmĕrip $=$ sĕmberrip, sěmberrit „klein schenkblad op voet” en sěmiang (Kedah) = sĕmbiang ,esv. visspeer" zijn uitspraakvarianten: $-m-:-m b-)$; (silir-) sěmilir "heen en weer zwaaien als het vrije eind van een sjerp"; sěminjak of gewoner sĕmĕnjak ,sinds”, naast sĕjak „sinds”; sĕmugup, sěmugut $=$ sĕngugut „dysmenorrhoea (a gen. name for diseases causing uterine discharges)"; sěmulan (Sumatra) „dansmeisje”; sĕmundï „esv. aap”; sĕmurup (Perak) ,nachtelijk onderdak in de jungle”, vgl. ber-sapar ,in een nachtverblijf in de jungle kamperen”;

1) Onder de met $p$ aanvangende woorden zijn enige niet geheel zeker : mogelijkheid van praefix $p \breve{e}-+$ nasalering. 
sěrunda „slepen (schip over land)”: tunda „,wat gesleept wordt”; tĕmabur „verstrooid” bij tabur „verstrooid, verspreid”; těmadun in adun-těmadun (min.) „kleurenmenging” bij adun „kneden”; těmalan், tumalain (Sumatra) ,, conical basket of bark used in bees'-nest-hunting" (er is echter een nevenvorm (Rawas) tĕmbilong); tĕmali in tali-tĕmali ,het touwwerk van een vaartuig”, (loban்) těmanà் ,zundgat van een kanon”; tĕmancal „dus”; tĕmandà „handsome appearance; bearing; port”, $t$. mĕntĕri ,the war-dress in which a slain soldier was cremated (vgl. tumandan bij tandan ,een bezoek aan anderen of vreemde landen brengen", Wilkinson)"; těmaram in taramtĕmaram „,bewolkt (van een maannacht)”, ook těran்-těmaram en těran்-tĕmaran்; ayun-těmayun ,heen en weer zwaaiend, schommelend” bij ayun ,schommelen en derg.”; těmĕgun ,in afwachtende houding” bij tĕgun „onbewegelijk recht-op staande etc.”; tĕpun těmĕlon „esv. koek” (těpun „meel”); těměngun் „titel van een waardigheidsbekle-

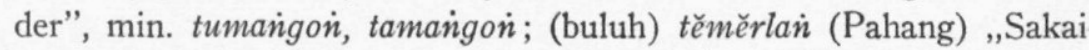
dartquiver", tĕmukut ,gebroken rijst" = mĕlukut; tĕmurun in turuntĕmurun „(freq.) descent after descent” (Wilkinson).

Gaan we deze lijst, waarin dus niet zijn opgenomen drielettergrepige namen van planten etc., die -е̌m-, -um- enz. bevatten, na, dan blijken de volgende groepen te onderscheiden te zijn: a) woorden, die een onordelijke, onregelmatige houding, toestand, verschijning aangeven of ook een voorwerp dat een zodanige indruk maakt en derg.; b) woorden, die een lichtverschijning, flikkeren etc. aanduiden; c) woorden voor bewegingen; d) termen voor gebruiksvoorwerpen en onderdelen van gebruiksvoorwerpen; e) opzichzelf staande termen als kĕmanten, jĕmĕran்; f) (sěmějak etc.) ,verlengde” voegwoorden. Naast deze indeling op semantische grondslag is een andere mogelijk: een etymologische: sommige $-m$ - woorđen hebben tweesyllabige woorden in het Maleis naast zich, andere niet, weer andere komen slechts in een vaste verbinding voor (type tali-těmali). Naar de ,woordsoorten" (moeilijk definiëerbare begrippen in een Indonesische taal) is op te merken, dat vele $m$-vormen geen werkwoord zijn noch op aannemelijke wijze tot een oorspronkelijke werkwoordsvorm herleid kunnen worden. Opvallend is voorts het grote aantal der $m$-woorden, die een of meer nevenvormen naast zich hebben, wat een kenmerk is van $\mathrm{zg}$. primitieve ${ }^{1}$ ) woorden in een $\operatorname{taal}^{2}$ ).

1) Over deze term: Bijdragen 99, p. 419 vlgg.; 431.

2) Ibidem, p. 463 vlg. 
In het Javaans vindt men eveneens woorden van drie syllaben met -um-, waarnaast geen disyllabum voorkomt of schijnt voor te komen. Uit de aard der zaak is het niet zeker, of zij in bepaalde gevallen toch niet bestaan hebben. Ik noem jumagar (verouderd) ,nog jong (biggetje)"; juměbrèd „ratelen”; gumuruh ,een verward gedruis maken”; gumrènjèn (vo.) „kletteren (van water door pijp)”; gumriwis „snateren"; kumabrug „met een smak neerkomen”; suměntěk „slank (meisje)"; sumlonon „vrijpostig”; sumrobod, sumrubud „gieren”; cěměndil „geitenkeutels”; těměndil „muizendrek”; tumambirang, tuměmbiran் „vol jeugdige hartstocht”.

Ook onder de talrijke Oud-Javaanse $u m$-woorden zijn eensdeels vormen als kuměmit naast kĕmit ,bewaken” en andere afleidingen van kĕmit, „werkwoordsvormen" bij woorden met overheersend ,intellectuele betekenis”, niet-primitieve elementen der taal. Deze behandelen we hier niet. Daarnaast staan echter verscheiden onomatopeeën en klanksymbolische woorden: kuměcěk „suizen”; kumětĕr

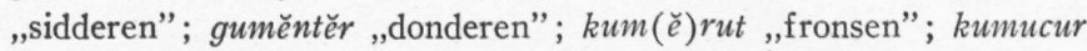
„uitspuiten" ${ }^{1}$ ). Ofschoon het materiaal uit de aard der zaak niet volledig is en wij bij onze conclusies derhalve zeer voorzichtig moeten zijn, valt het op, dat bij verscheidene dezer vormen naast grondwoord en eventuele verdubbeling alleen een vorm met um voorkomt: gumuruh „dreunend, bulderend”; kumĕtĕg „kloppen”; kumĕtug „bulderen”; kumusik „sissen, suizen”; kuměñar (ook kiněñarakěn komt voor) „stralen”; kumutuk „met de knokkels slaan”. In deze groep, die geheel overeenstemt met Maleise woorden als gĕmilan, gěmuruh, gěměntam en dergelijke, is een voorliefde voor $g$ en $k$ aan het begin op te merken.

Voorbeelden uit andere Indonesische talen : gajo jĕmĕrak „luidkeels lachen (meestal van velen tegelijk)"; s.v. jĕrak vraagt Hazeu ${ }^{2}$ ) zich af: „stam van jěměrak”, wat een onnodig vermoeden is; sasak tĕmonen் „dooier (ei)"; těmanden் ,wesp”. Ook in een woord als sasak

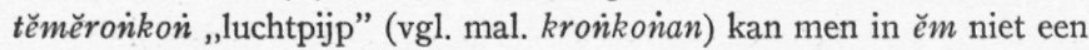
werkwoordsvorm-afleidend infix zien.

Atjehse voorbeelden zijn: jömöran (gebruikelijke spelling djeumeurang) „oversteken”; gömöréb ,uit angst gillen” (göréb is ongebruikelijk tekent Djajadiningrat's woordenboek aan); gömöcië’. (geumeutjië’) „van pijn gillen” (als voren); kömudöë ,roer”; kömu(n)ca'

1) Een uitvoeriger opsomming: Remarks, p. 203.

2) G. A. J. Hazeu, Gajōsch-Nederlandsch Woordenboek (1907), p. 185. 
„top” ; kömuraïh „,donderbus” ; kömuröën ,,vastgezet roet”; $\operatorname{sömam(b)u~}$ „knuppel”; sömanat „levensgeest”; sömaran „,roodachtig, voskleurig”; sömöria ,uitstralend; zwaar ademhalend, drukkend (van het weer)”; sömönöb ,gapen”; sömilu I ,scherpe rand van gespleten bamboe”; II „verblind door schel licht”; sömintō $\dot{n}$, naast sölintōin en sönintōं „esv. paarlmoerschelp”; sömirà் naast tömiran் ,want van een vaartuig”; tömöntü̈' „(feest)geschenk”; tömika, timika „scherf”; tömuda, tumuda ,oudere zwager of schoonzuster".

In het Mori vormt het element $u m$ enkel- en tweevoud van de „,deelwoordsvormen" van transitieve werkwoorden met bepaald object en van een groep intransitieven. $\mathrm{Er}$ is echter ook een groot aantal $u m$-vormen, die volgens Esser ${ }^{1}$ ) geen werkwoordsvormen m e e r zijn, maar adjectieven; $u m$,,is van deze woorden een onlosmakelijk, geheel tot de secundaire stam behorend, bestanddeel gaan uitmaken", bv. rumodi, gezegd van mais, waarvan de korrels zich pas beginnen te vormen (vgl. merrodi ,gebobbeld”). Ook substantieven met um komen voor, bv. rumaa ,esv. uil”, lett. „,schreeuwer”, rumaa kan ook ,zeer hard gillen" betekenen.

In het Bare'e is volgens Adriani ${ }^{2}$ ) ons element ,geheel verstard”; het komt veel voor in geluids- en bewegingswoorden: gumèrèko „rammelen”, kumaraíkiji ,gillen”. Het geval doet zich in deze taal meermalen voor, dat voor een um-woord het praefix mo- komt. Adriani ${ }^{3}$ ) houdt het er voor, dat deze woorden verstarde -um-vormen zijn, waarvan men de ,eigenlijke betekenis” weer zal hebben willen verduidelijken door het praefix mo- er voor te voegen. Daaruit volgt volgens hem, dat -um- oorspronkelijk dezelfde betekenis had als mo-, dat het nl. ,intransitieve actieve deelwoorden” vormde. Dit is een gevaarlijke redenering. Ten eerste is het niet uit te sluiten, dat ook wanneer het vormen met infix $-u m$ - waren en wel met een andere betekenis van -um- dan die van mo-, er later mo- vormen op gebouwd zijn. Maar als aannemelijk gemaakt kan worden, dat um in deze woorden geen affix is, komt de redenering geheel te vervallen. Als voorbeelden noemt Adriani sumao ,janken (liever: miauwen) van een kat", dat mosumao wordt en rumaíku ,klappertanden”, dat morumanku wordt. Bij het eerste de aantekening, dat juist de klankcombinatie mau veel gebruikt wordt om het geluid van een kat weer

1) S. J. Esser, Klank- en vormleer van het Morisch, § 366.

2) N. Adriani, Spraakkunst der Bare'e-taal, § 182.

3) Ibidem, § 183 . 
te geven, wat de waarschijnlijkheid, dat de $m$ hier tot een infix zou behoren, geringer maakt ${ }^{1}$ ).

Zoals ik reeds vroeger ${ }^{2}$ ) opmerkte schijnen enige der bovengenoemde vormen, vergeleken met hun grondwoord, een emfatische of intensieve waarde te hebben, bv. kumětug, gumĕntěr, in de in Juynboll's Woordenlijst genoemde teksten. In onomatopeeën met de betekenis „donderen, rommelen, dreunen en derg." schijnt het element $u m$ deel te hebben aan de door het woord in zijn geheel uitgedrukte imitatie van bepaalde geluiden; $u m$ schijnt mij in oj. gumuruh en derg., en evenzo in mal. gĕmuruh en andere deel te nemen aan de klankexpressieve waarde van het woord in zijn geheel. „Es ist uns verständlich”, zegt ook Brandstetter ${ }^{3}$ ) naar aanleiding van soend. gumurudug, ,dass der Laut $r$ das Rollen des Donners, der Laut $u$ den dumpfen Ton desselben nachahmen kann” (liever: ,een adaequate indruk wekken kan als van....”). Inderdaad wekt de combinatie van de $r$ met een $o$ of $u$-vocaal de indruk van een gerommel, gedreun, dof geraas; vgl. bv. ned. rommelen (,,een voor het taalgevoel onomatopoëtisch woord" 4$)$ ), (16e eeuws) rompslomp, onomatop. tussenw. bij „,in-het-wilde-weg slaan"; ronken, roffelen, grommen, brommen; fr. gronder; grondement; grogner, grommeler; ronfler ; roucouler ; ronronner; bourdonner; duits murren; brummen ; rummeln; grunzen; grommeln; eng. grumble; litaus niùrniu ,rommelen”; deens gumre „loeien, bulken” (ook „,van harte lachen”). Vaak komt in dergelijke woorden bovendien een nasaalvorm, die een indruk wekt, die adaequaat is aan die van aangehouden geluiden: gr. $\beta \delta$ ó $\beta$ os , het brommen”; $x \lambda \alpha \gamma \gamma \dot{\eta}$ „klank”; du. trommeln; fr. résonner; ned. zoemen; brommen etc. ${ }^{5}$ ). Soend. gumurudug is een zeer geschikt woord om een aanhoudend gerommel als van de donder weer te geven en er is m.i. geen enkele reden $u m$ hierin als een infix te beschouwen van dezelfde orde en waarde als -um- in kuměmit.

Het wil me evenwel voorkomen, dat er nog een derde groep umwoorden te onderscheiden valt, die dus niet tot de groep onomatopeeën

1) Waarover L. Sainéan, Les sources indigènes de l'étymologie française (1925) I, 55 vlg.; 2, 24 vlg.; 410 vlg.

2) Remarks, p. 203.

s) R. Brandstetter, Die primitiven Schöpfungen und die Höchstleistung des indonesischen Sprachgeistes, p. 14.

4) Franck-Van Wijk, Etymologisch Woordenboek der Nederlạndsche Taal, p. 557.

5) Vgl. mijn Remarks, passim en daar geciteerde literatuur. 
en klanksymbolische woorden behoort, maar evenmin met kuměmit gelijk gesteld mag worden.

In de eerste plaats valt er op te wijzen, dat $u m$ ook voorkomt in woorden, waar geen redelijke grond aanwezig schijnt te zijn voor de opvatting, dat ze verstarde verbaalvormen zouden zijn. Ik noem mal. tali-těmali ,allerlei touwwerk”; gĕmunci naast guci „,waterkruik”; taram-těmaram „donker”; min. tumalan் „mandje van honinggaarders", en verwijs verder naar bovengenoemde voorbeelden. Waarom men in tali-tĕmali wel een werkwoordsvorm zou moeten zien ${ }^{\mathbf{1}}$ ) en in sayur-mayur ,,allerlei groenten”, ciak-miak ,voortdurend gekweel”, tawar-mawar ,flauw met verscheidenheid”, serta-měrta ,onmiddellijk” niet, wordt mij door verwijzing naar het infix -um- niet duidelijk.

Ten tweede: naast mal. cěmorikah, dat een idee van wanorde aanduidt (č̌monkah-cěman்kèh ,sticking out confusedly in all directions”, Wilkinson), vindt men ook cěroinkah (cěroìkah-cĕronikèh, ,disorder or confusion", Wilkinson). Indien werkelijk zowel ĕm als ook ěr, waarover beneden, in deze woorden infixen met bepaalde grammatikale betekenis zijn of geweest zijn, en $u m$ bv. een ,intransitief actief participium", ar een frequentatief vormde, hoe is dan te verklaren, dat deze beide vormen met de zelfde betekenis voorkomen? Maar bovendien: het schijnbare frequentatief-infix wisselt ook met andere elementen, zo met -an-, eveneens in woorden, die geen verbaal begrip aanduiden: mori salampé en sanampé: mal. salampai „kapstok en derg."; met het aannemen van dissimilatie van $n$ en $m$ komt men niet steeds uit.

Ten derde : naast gěmě-, gumě- vindt men in het Maleis ook gědě-: gĕděbah-gěděbuk ,ploffend neervallen”, waarnaast gělěbak-gělěbur en (batav.) gěděblak-gěděblok; gědudup ,ratelen”, gěděban ,to bang with a stick or fist", naast gěměntam, gěměntar etc. Aldus bij onomatopeeën; maar ook bij substantieven die geen klanksymbolische waarde schijnen te hebben vinden we gĕdĕ-: gěděbir, gědabir = gělambir „,halskwabbe”; gĕděboin ,a bamboo vessel fitted with a cover” etc.; gědĕgap „ruw”; jav. gĕděbĕg (gewest.) „esv. vrachtkar”; gěděbog „stam van een banaanboom". Ook kĕdě-woorden komen voor: mal. kĕděnkan் „herhaald klinken”, maar boeg. kadaíkan் „knop van een

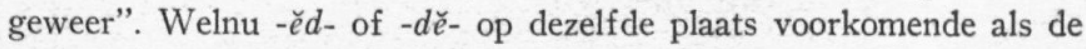
andere elementen (-um- etc.) kan niet als infix beschouwd worden.

1) Zoals bv. ook Hoesein Djajadiningrat, Atjehsch Woordenboek, I, p. VII in kira-mira. 
Alvorens een meer positief antwoord op de vraag te geven hoe deze ,derde soort" um-woorden beschouwd kan worden, wijzen we er op, dat in het Maleis en verwante talen een aanzienlijk aantal woorden in meer dan één vorm voorkomt en wel zo, dat de ene langer is dan de andere op een wijze, die in het algemeen geen aanleiding heeft gegeven te spreken van infigering. De meeste dezer woorden hebben trouwens nog nauwelijks bijzondere aandacht gehad. Soms kan men aarzelen, of de leden van een stel in betekenis overeenkomende en in vorm op deze wijze op elkaar gelijkende woorden inderdaad etymologisch bijeen behoren. Zo bv. bij mal. banai „wat men heeft opgegeven (van werk dat de moeite van het afmaken niet

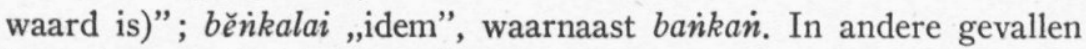
heeft het ene dialekt deze, het andere gene vorm, of staat naast een meer algemeen verbreid woord een dialektische variant (hieronder nog enige voorbeelden): batav. bětahak „oprispen”: kedah bĕlahak, ook běkahak, kahak etc. komen voor; bovendien is hier zeer onzeker, of men een vorm *bahak als ,grondwoord" mag construeren; waarschijnlijker is wel, dat we hier met een variantenreeks van onomatopoëtische aanduiding van een bepaalde met zekere geluiden gepaard gaande handeling te doen hebben. Onzeker, wegens vermoede herkomst uit het Chinees, is ook het Baba-Maleise bojincen ,ondankbaar” naast bochen, dat Bataviaas is. In de uitgebreide variantenreeks voor "de mond openen, begerig naar voedsel (van kinderen) etc." $\dot{n} a p$, cěñap ,in de mond nemen”, íĕnap „hijgen”, puñap, unap „naar adem hijgen", cunap, inu்ap komt ook voor cěluñap, wat men wel als -ělvorm (geïnfigeerd) bij cuñap zal hebben willen beschouwen, al is er niets tegen het een "lu-lasvorm" bij cěñap te noemen. Men vindt n.l. gevallen als bintul, bintur „krabnet”: bělintul; cunut „borstbeen in een vogel" naast cěnonot, ,idem"; (met dialektverschil) curam (Johore) „plotselinge helling”: cěnuram (Kedah); cĕrboh „slechte manieren; zich lomp en boers gedragen": cĕroboh; cĕrlï (Perak) „spreeuw”: cěrulin (Batavia) : cěpěrling, cěmpěrlin (de gewone vorm), naast bĕrlin, pěrlin, těpěrlin; condon் „naar één zijde hellend, schuins": condĕron (wil men hier een - ̌r $r$ - infix aannemen, dan is toch vreemd, dat het in de tweede syllabe van het ,grondwoord" optreedt) ${ }^{1}$ ); conten ,insmerend, vuil makend": contěrin (Java); cura, curi ,een zwaard" (waarnaast corek, curek ,long-handled knife for cutting rattans”): cundĕrik (Java) ,een mes van het type hakmes”; mĕndaga ,to walk

1) Over gevallen met $r$ en $l$ beneden nader. 
uphill, to work against adverse conditions"; daki ,uphill work, climbing": dahagi ,uphill work, work against adverse conditions"; Wilkinson (I, 335) vergelijkt met „batav. from Jav. kubil „swollen, enlarged" " kedah gĕdubil ,coarse-looking, e.g. thick-lipped of heavyjowled"; naast de onomatopee (měri)gělěbak ,to give out dull rapping sounds" staat het batav. gĕděblak; naast gubir, op Java gembel, staan gělambir, gělimbir, gědabir, gělabir, gědobor, gělěmbur etc. „hangend stukje vlees, halskwabbe etc.”; gěnar ,aarden vuurplaats om er suiker op te koken etc.” : gĕnahar, gĕnohor; op Java staat naast arip ,,slaperig” batav. měn-gĕriap ,idem”; gěrok-gěrak (onom.) ,,allerlei rommelende geluiden": měngerodak ,ratelen, rommelen"; naast de onomatopeeën gěrsak, gĕrsek, kĕrsek, gěrsok staan gĕrosak en kĕrosok, alle aanduidende ,een geluid als van een voetstap op nat zand”; naast měnjělin ,zijwaarts kijken" vindt men een aan het eind langere vorm jĕlinar; Wilkinson (I, 465) brengt met apit ,tussen .... in klemmen" in verband mĕnjërapit ,to join by pressure, i.e. to twist or squeeze several objects into one", waarnaast mĕnjĕrepet; naast jĕrpak „plotseling komen bij” staat bĕr- of měn-jĕrěmpak, ,to come across anything unexpectedly, e.g. to meet a tiger on the forest-path", naast jawain ,esv. hagedis" komen voor jiawan en bijawak, biawak; naast kedah kĕlati ,arecanootsnijder" staat op Oost-Sumatra kalankati, in Minangkabau kalakati etc.; naast kěkut „opkrullen”, staat kěrěkut, dat ook gebruikt wordt ,of the closing hand and of a man who ,coils round" anything that belongs to him and refuses to part with it", daarnaast kĕděkut (Kedah) ,gierig”; naast kěrak ,afval aan de binnenwand van een rijstkoker" staan kĕrdak ,bezinksel, droesem”, kĕrodak ,idem”, kĕladak „droesem, afval aan de binnenwand van een kerriepan”; kěrsek „kiezel”: kĕrasek, kĕrisek; kĕrtan் „esv. vis”: kĕratan்; kĕrbas „leegschuddend”: kěribas, ook kĕbas ,afkloppen en uitschudden” en kibas ,hevig schudden” komen voor; kĕrbon் „rijstkist”: kěrubon (Perak) „moveable rice-bin of matwork or bark"; in Palembang luidt ,achtergebleven in de groei" kĕrit, in Penang kĕrĕntut, in Penang kĕrĕncat, verbreider is kĕrěntat, těrincat; naast kĕrdil ,,achtergebleven in ontwikkeling, rijp maar klein" staat kĕritil "gerimpeld, verschrompeld”; (Johore, Kelantan) kĕrtok „esv. veebel” : (Perak) kěrotok „wooden clapper used as a buffalo-bell”; naast kĕrut ,voren, diepe groef op het gezicht etc.”: kĕrotot „diep gevorend" (nevenvormen kĕdut, kĕlědut e.a.); kĕrsan் (Kedah) ,borstspeld": kĕrosan (Penang etc.), kĕronsain (Riouw), kĕronisan் (Java); kĕrsut ,het gezicht rimpelen als een kind dat gaat schreeuwen": 
kĕrusut, kĕrěsut, kĕrotot, kĕrudut; kĕrsul (Kedah) ,stijf en ruw (van haar)": kĕrusul (Singapore); naast Palembangs kidin ,grote mand van grof vlechtwerk" staat minangk. kětidiñ; (vgl. ook kěbabal ,half grown jackfruit": kěmbabal, min. timbabal; kětimbabal, (Java) babal); naast de uitdrukking mati kumlah ,natuurlijke dood”, staat in Kelantan gěmola, gěmolah „wijlen, de overleden; de manes van overledenen”; lanisuir ,esv. boze geest”: lanisuyar; naast lodoh (Kedah) „,zacht door bederf” staat te Batavia lodrok, ledrek „zacht door overrijpheid, van fruit”; pantun „pantoen”: běhasa pělanten; pělbaya (Ked.) „beul”: pělěmbaya; pěpojok (Batav.) „hoek”: pělojok: pěloksok (Batav.) „hoek van een kamer”; pĕrgam „esv. duif”: pĕrakgam; pisañ²: (Kedah) pěrisà் „rubbing-strake on a Malay boat”; pěrsok „door foutief gedrag vallen, zinken, terechtkomen in": pěrosok; sampah: sěrampah „droog vuilnis”: sampělah „oud vuil”; sělěpat „,besmeurd”: sěmpělat „met vuil bespetterd”: sěrnok, ,aangenaam” : (Kedah, Perak) sĕronok; sĕrbah ,in wanorde”: sĕrobah-sěrobeh ,idem”; sĕrpeh „splinter, spaantje”; sěrupeh; sĕdam (onom.) „,het dreunen van een kanon”: sĕdĕram ${ }^{2}$,het geratel van geweren”; sělok „met de hand tasten naar iets, dat men niet ziet": měnyělodok (sělodok) ,to push one's way into (with the hands)"; Wilkinson (II, 397 en 422) verbindt sembat „whipping up with a jerk” met sěberrot (Batav.) „highway robbery; theft with violence; snatching from”; sěnkan „dwarshout

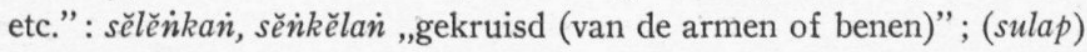
main sulap „vlug met de handen”, suñlap: sěrkělap „ontfutselend”, sangělap ,insluipdief”; sompek „met spaanders, inkepingen”: sompělak (Batav.) ,gehavend aan de rand”; tapak „voetzool”: (op Java) tělapak; min. tunjuk ,wijsvinger”: tělunjuk; tĕrjun „afspringen, afvallen": těrajun (Broenei), tĕrujun (Baba-Mal.); tubin „esv. visfuik”, těrbin: těrubin. - Voorts is te vermelden het reeds door Wulff ${ }^{1}$ ) gesignaleerde type kĕlěmbai „land-slak”: kĕlěmbu(w)ai.

Ook in het Javaans komen verscheiden stellen van dergelijke woorden voor. Ik noem de volgende: micik (gewest., spreekt.) ,altijd of te erg op eigen voordeel bedacht zijn, anderen het gelag laten betalen": mběkicik "listig steeds zich zelf trachten te bevoordelen" (dit geval is, daar er verscheiden met mbě- aanvangende trisyllaba zijn, mogelijk ook anders te verklaren); mońkron் „ergens op hurken”: mětonkron் (gewest. spreekt.) „op de hurken (gaan) zitten”: mběkon்-

1) K. Wulff, Z. D. M. G. 62 , p. 686 , waarnaar ik verwijs; vgl. ook Van der Tuuk, Tobasche Spraakkunst, p. 111 (§ 52, 5). 
kon (verouderd) „hurken”; mbogol „niet behoorlijk gekleed” : bĕdugul (verouderd) ,,idem”; běrcuh, běrcoh (gewest.) ,alles door elkaar”: brancuh, brancoh (verouderd) ,door (naast) elkaar (goed en slecht)"; mbĕrsot „zich uit de voeten maken”: mbrosot (gewest. spreekt.) „(stilletjes) wegglippen”; mbrisat „,idem”; ndaplan „met uitgebreide armen (vooral: dwars over de weg) staan (om tegen te houden)": njěpaplà் ,met (onbehoorlijk) wijd uitgebreide armen (en benen komen te) liggen”; nd̆ěkĕr (spreektaal grof) : ndĕkěkěl (gewest.) ,ineengekronkeld liggen (te slapen)”; njoinok ,(als hond, kat gaan) zitten (d.i. met verticaal gestrekte armen, voorpoten) etc." : nděñonok ,idem”: njĕñoniok ,de hals uitrekken (zitten uit te rekken) om te kunnen kijken”; njẹdig (gewest. spreekt.) „met wijd uitstaand haar (slordig of breed opgemaakt)”: njẹdididig ,idem”; njĕglig (spreekt.) „ketsen, niet verder kunnen”: njëgagig (verouderd) „plotseling ophouden (met een beweging)"; njlěngut, njlěñut (gewest., verouderd) ,,aandachtig bij zijn werk zijn”: njĕgungut (spreektaal) ,(met aandacht) ergens iets gaan doen, komen zoeken"; jèmbit, jèmbèt (spreektaal) : jĕmbélit (gewest.) ,buiten spel roepen, even ophouden met het spel etc.”; jĕmblonan (gewest.) „verstoppertje spelen”: jěmbélunan (gewest.) ,idem”; (junkir (-rvalik) ,op zijn hoofd (gaan) staan”: jĕnkělit ,over de kop buitelen”, kan verschillend beoordeeld worden); njèplěm (gewest.) „,met stijf gesloten mond (blijven zitten)”: njĕpaplěm (gewest. spreekt.) ,idem”; (mak)jlalat ,wilde, onrustige blikken in het rond werpen": (mak)julalat (verouderd) „wild rondkijken"; nduwwèk (gewest. grof) „blèren, huilen”: juwèzwèk ,'n wijde, brede mond trekken”; gabel, gabrul (gewest. verouderd) ,bevuild met drek, wat is blijven kleven”: $\dot{n}$ gědabul ,met modderklonten aan de voeten”; gadug „kunnen reiken tot”: gědégug „ergens bij kunnen”; gěbal (dalěm) (verouderd) „(Uw) onderdanige diena(a)r(es)”: gědibal ,idem” (eigenlijk betekenen deze woorden ,modderkluit aan het schoeisel”); gila (spreekt.) „onwijs, gek”: gěndila (verouderd) „zich gek aanstellen”; glélan்-glèlèn (verouderd) „met gemaakte houding lopen”: gěmbélan்-gěmbèlèn ,het hoofd onder het lopen heen en weer bewegen, - onder het lopen laten vallen"; ngambèr (verouderd) „hangen te bengelen”: ingěbambèr „laag, lang erbij hengelen”; $\dot{n g l e ́ l o ~}$ (verouderd) „slap knikkebollen”: ingěmbélo ,een zwaar gevoel in het hoofd hebben (roes)”; sorot „straal”: sěmprot „spuiten”: patin sĕmporot ,in een straal te voorschijn spuiten”; sěsulih ,plaatsvervanger, vertegenwoordiger": sěmbulih (verouderd) „,vergoeding”; surat ,met een streep (kleur), (licht)straal”: sěmburat ,een tintje krijgen”, 
waarvan sumamburat ,glinsteren, stralen”; sĕmprul (gewest.) „minderwaardig": sěmporolan (gewest. grof) „hoer”; saíklètan (verouderd) „esv. klem”: sěnkělit (gewest. verouderd) ,in de gordel gedragen".

Er zijn paren, die grotere verschillen vertonen, bv. mal. jĕnikĕrèk „molkever”: kĕridèk ,id.”. Men vergelijke ook gevallen, waar tevens andere variatie, bv. in het woordeinde optreedt: jav. inrémpyan „overdadig veel (ergens aan hangen etc.)": nrěmpayak ,dicht (gebladerte)”; nrĕmbyun் „vol staan (gebladerte)": ìrěmbuyun „idem”: inrěmbuyuk „zwaar (dik) erbij hangen" etc.

Oud-Javaanse gevallen zijn met meer of minder waarschijnlijkheid: kindayut „knijpen, knellen, omklemmen”: njav. veroud. kayut „vast-, bijeenbinden”; kilusuh „verlept”: kisut „verschrompeld”; kucupak „plassen”: kuñcak „klotsen”; tahulan ,been(deren)”: mal. enz. njav. gewest. tulan் „,bot”; duhilatěn en duhilatěk ,zijn speeksel opslikken”: dilat ,likken”; bahĕlun் ,,beenderen”: balun ,,been”; suririn ,voortduwen(?)”: surun „duwen”; tan sinipi (Kid. Pam. 4, 184): tan sipi „niet gering”. Op het bestaan van varianten wees reeds $\operatorname{Kern}^{1}$ ): kapalěyö doet zich voor als een frequentatief of intensief en is slechts een gewijzigde vorm van jav. kalěpyuk, kěropyok, krupyuk...,, ,geluid van een gebruis, geklater”. Kern neemt als „stamvorm” aan pěyö, geinfigeerd met het ,intensief-invoegsel”: palěyö etc.; in kĕropyok is dan ěr geinfigeerd in het met praefix voorziene pyok. Ik zou hier noch van stam (grondwoord), noch van affixen spreken. Voorts : kĕděpěk naast kěrěpěk „strompelend geluid maken”;

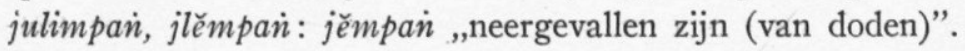

Soendase gevallen van doubletten of tripletten, waartussen het verschil bestàat in een inwendig meer of minder, zijn o.a. jamburan் ,allerlei kattekwaad uithalen”: jamburaul, jambraolan; jurain „diepe

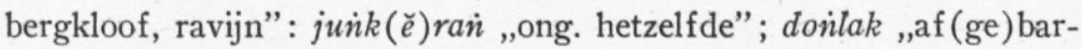
sten (een stuk van een muur, tafel etc.), stukstoten": doiklak; garui „ongebruikt laten liggen (sawah enz.)": gamblun $(<g a+$ nasaal + lun $<^{*}$ galun met inwendige nasalering, na te gaan zou zijn, in hoeverre gamblun twee- of driesyllabisch is; overeenkomstige overwegingen zijn bij de twee vorige gevallen mogelijk); waarschijnlijk: talan ,iemand die in plaats van een ander iets doet of ondergaat, waarneemt, vervangt": tambalan ,invallen, interromperen"; suni $=$ buni „verborgen”: samuni (dialekt van Djatiwangi) „zich verber-

1) H. Kern, Kawistudiën (1871), p. 98 vlg. 
gen" ${ }^{1}$ ); gonjok „omsingelen": goronjok; jodar (dialekt van Koeningan) ,zorgeloos, achteloos”: jolèdar ,idem” ${ }^{2}$ ).

Interessant zijn ook de driesyllabige umpak basa's (,,werkwoordelijke tussenwerpsels") in het Soendaas, die van de gewone vorm ${ }^{3}$ ) afwijken : burahol ,ineens voor de dag komen”; jangèlèk ,zich opeens in zekere gedaante vertonen”; jëtětět ,boos”; gandöan „,heengaan”; gantawain ,uitschelden”; gujubar ,neerplonzen”; kudupruk „,vallen” e.a. $\left.{ }^{4}\right)$.

In het Gajo: gĕlok ,inzinking in het terrein, laagte, gaten (in de weg)": gĕlědok, gěldok ,inzinking in het terrein, deuk"; kĕlon, kělun ,inzinking, plooi, holte, diep (van een bord) etc.”: kěldun ,diep (van een bord)": kĕltuin,,inzinking, verzakking in de bodem of in een rivierbedding" (verschil in woordvorm gaat hier dus met een zekere nuancering en differentiatie in betekenis gepaard); een merkwaardig stel is rigöp „druk in beweging, met velen in actie zijn”: rěngiöp „door elkaar krioelen, wemelen (van mieren, mensen)”; sěngěgin „,snikken” in het Laoet-dialekt: sěngěgikön „,snikken (van huilende kinderen)"; tapak "palm (van de hand), zool (van de voet)": těmpapak ,idem”; těrban் ,vliegen”: těmerban்; meer dan eens in geografische namen, bv. Tōwéran = Téran, een kampoeng aan het Meer; geen voorbeeld is: laoet cawardi, gajo-loeös cawarudi „,blauw glazuursel op gevesten”, leenwoord $=$ mal. etc. lajuardi.

In het Tontemboan: taikas ,zich openen (van de hemel, doordat de wolken zich scheiden)": taikělas ,leeg (van een hemel zonder wolken etc.)”; (Makela'i-dial.) tointok: Matana'i-dial. to'tok „merktekenen op een kerfstok zetten"; wareke „omwenden": warukeke, ampěren ,een kleine steen etc. onder haardstenen”: ampen் „,wat toegevoegd wordt aan een vracht”; vgl. ook gevallen als ta'tas ,doorhakken”: tarĕttěs „krakend geluid van brekende bomen”; gevallen als kumiput ,het lichaam ineentrekken en in omvang kleiner maken": kilipus ,,ineengedoken met over elkaar geslagen armen zitten, in zijn schulp kruipen”; een geval als tunkani: toruíkan ,uitstorten van droge waren" komt beneden ter sprake.

In het Bare'e: galedo ,,iets wat men aan een kind geeft om het te sussen”: galagido; tabinke „oever”: tadubike (priestertaal) „steile oever”; $k a p u$,overdekken”: kadapu ,vlies op gestold vet etc.”.

1) Gegeven van den Heer A. C. Deenik.

2) Gegeven van Mr. Goenara.

3) Waarover beneden.

4) Zie R. A. Kern, Bijdragen 102, 85 vlg. 
In het Ngadju-Dajaks: karup ,das Getön wenn man harte Dinge kaut" (Hardeland): karutup; kambaröt en karamböt tegenover karöröt ,gerunzelt”.

Welbekend in de Indonesische talen zijn de tweeling-uitdrukkingen, zowel onomatopoëtische en derg., bv. mal. děgok-dĕgak ,geluid van het inzwelgen van een vloeistof", als andere: mal. sayur-mayur ,allerlei groenten”. Behalve de groepen die ik vroeger besprak ${ }^{1}$ ) is er nog een, nl. die waarbij het ene, en wel gewoonlijk het tweede lid langer is dan het eerste ${ }^{2}$ ) en wel van de gedaante van de in dit opstel behandelde uitgebreide woorden: gěmuk-gĕděmpuk „dik”;

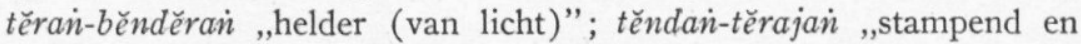
schoppend”; gĕgak (gěgap)-gěmpita ,,donderend, zeer lawaaiï"”3); gělap-gělěmat ,diepe duisternis” : gělap-gulita ,idem”; gulun்-gĕmulun ,in rollen of kronkelingen”; arai-jĕmarai (ked. jĕrai-jemarai) „trailing untidily as broken twigs”; julai-julita (jëlita) ,teer, slank-bekoorlijk”; alan-kĕpalan „buitengewoon gering”; garicau-picau ,gesjilp”; kokok-kěriok „kakelen en kraaien”; kopès-kěropès ,afval”; silansělisih ,gebrouilleerd zijn”; azwan-kĕmazwàn ,de wolken”; vgl. ook kĕrin-kerontan ,uiterste droogheid"; in het Javaans heeft men alot „taai" en kĕmalot ,taai, met veel weerstandsvermogen” naast elkaar. Zo in het Ngadju-Dajak: tampak-tabauk ,bovenmatig dik”.

Er komen ook gevallen voor waar het ,ingeschoven” element tweesyllabig is of schijnt te zijn: mal. kělěnikiak „esv. mier”: kiak², maar kěkiak komt ook voor, en hierop zal de viersyllabige vorm gebouwd zijn ; sědan: sělasadan ,hik(ken)”(?).

Boven kwam reeds ter sprake, dat soms in het ene Maleise taalgebied de kortere, in het andere de langere vorm voorkomt, althans wordt opgegeven. Men vindt echter ook gevallen, waar de ene Indonesische taal de korte, een andere de uitgebreide gedaante van het woord vertoont. Vgl. atj. tayan „watervaatje”: mal. tĕmpayan, ked. mal. těpayan. Naast jav. kèlèk ,oksel”, mal. kèlèk „onder de arm dragen”, tag. kili-kili ${ }^{e}$ „oksel” etc. IN. kilik, kili ", ,oksel” heeft het Gajo krèdèk „oksel”. Tegenover ngdaj. ampit „rijstvogeltje” staat bat. amporik ,idem”; mal. jonkok „neerhurken”: min. jaroinkok: jav.

1) Remarks, p. 186 vlg.

2) Dat het tweede lid gewoonlijk langer is, is in overeenstemming met overeenkomstige verschijnselen elders; zie Bijdragen 100, p. 129.

3) Gewoonlijk brengt men (Pijnappel, Wdb.; Klinkert, Wilkinson) gěmpita in verband met skt. kampita- ,sidderend, trillend; siddering", hetgeen mij om semantische redenen niet waarschijnlijk voorkomt; eerder is het een nevenvorm van germpar „opschudding; rumoer, getier”, vgl. julita, gulita. 
junkruk ,met het hoofd gebukt staan”; tag. kubkob „omsingeld”, tbat. hup-hup ,bedekken”, jav. kukub ,bedekt, met iets over het gelaat”: jav. krukub ,met een kain, doek etc. over zich heen": ngdaj. kalukup ,deksel”; jav. cacah ,fijngehakt, stukgesneden”: tag. sala$s a k$,vernietiging” (,mit erstarrtem Infix” $\left.{ }^{1}\right)$ ); tbat. pattar ,verhoogde vloer”: ngdaj. parantaran „,voorgalerij” ${ }^{2}$ ); tbat. pukpuk „stukgeslagen zijn”, tag. pukpok ,hamerslag”: tag. pagukpok „knotslag” (,mit erstarrtem Infix" $\left.{ }^{3}\right)$ ), een oude onomatopee; jav. putun ,,geheel stuk", mal. poton ",afgesneden”, ngdaj. ponton ,afgehouwen”: tag. puluton „,stuk (subst.)” (,mit erstarrtem Infix” $\left.{ }^{4}\right)$ ); tbat. sisik „luizen”: mal. sĕlisik „uitpluizen, navlooien, in de veren strelen, aaien”, jav. slisik „,in de veren pluizen”; mal. sisip „tussen iets steken (bv. de kris tussen de gordel)”, hova sisikă ",indringen” ${ }^{5}$ ): jav. slisipaké ,,stoppen in”, tag. salisip „,doordringen”; mal. kainkan „,wijdbeens staan, wijd openstaan (deur)": mal. kĕlanikañ ,de plaats tussen de beide dijen”, tbat. halakkain ,idem”, tag. kalankain ,wijdbeens staan” (,mit erstarrtem Infix" $\left.{ }^{6}\right)$ ); tag. kulog „,donder”: jav. krudug ${ }^{2}$,rammelen, stommelen" mogelijk een oude onomatopee; vgl. daarbij of daarnaast jav. gludug „donder”; jav. (dial.) sělipaké „stoppen in of tussen”: mal. (Penang) sělip $=$ sĕlit , ingeklemd tussen twee oppervlakken": gajo sĕlgep ,tussen iets, bv. tussen de voegen van iets steken"; mogelijk: soend. sěbit ,openrijten (van de huid), aftrekken (van de schil van een onrijpe pisang, zodat er van het vruchtvlees iets aan de schil blijft zitten)": gajo sělibit ,even langs schaven van een wapen of kogel, schampschot, even langs de oppervlakte strijken"; met nuancering in betekenis: mal. p̌̌-sawat „drijfmiddel, beweegmiddel (zoals bv. een drijfriem, horlogeveer)”: gajo sěnawat „zweep om buffels aan te drijven"; mal. condon் ", hellen, overhellen, dalen (van de zon)"; cěnděron் ,overhellen(d), neigen tot”, vgl. gajo (g.-loeös cěnduñ ,overhellen tot”: gajo cĕrĕndun ,idem”); tag. sapot „,doodskleed”, tbat. saput ,idem”, mal. saput ,bedekt”: ojav. salimput ,hullen in” (cf. mal. sĕlimut ,idem”); mal. tapak (tělapakan) „voetzool etc.”: soend. talapak ,voetzool etc.”; mal. těngilin ,miereneter”: jav. $t(\breve{e})$ rĕngilin

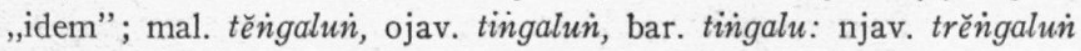

1) Otto Dempwolff, Vergleichende Lautlehre des austronesischen Wortschatzes, I, p. $60(\S 42$, a, 2$)$.

$\left.{ }^{2}\right)$ Behoort tot dit grondwoord alles wat Dempwolff, o.c., III, p. 114 vermeldt?

3) Dempwolff, o.c., I, p. 111 , § 55 , a, 8.

4) Dempwolff, o.c., p. $37, \mathrm{I}, \S 26$, c.

5) Vg1. Dempwolff, II, p. 104, § 111 a, 1; III, p. 155.

6) Dempwolff, o.c., I, p. $114, \S 55$, d, 5 . 
„esv. marter”; mal. kuku ,nagel, klauw”: mak. boeg. kanuku ,nagel”; ment. tanai „faeces”: jav. mal. etc. tahi ,idem”.

Ook leenwoorden worden wel op deze onsystematische wijze verlengd: skt. śāpa- „vloek”> mal. sĕrapa(h), een vorm die duidelijk ontstaan is door anaptyxis uit het eveneens voorkomende sĕrpa < śäpa, met ,spontane" $r$; (op Java) mal. sěrěnta naast sěrta ,tezamen met", dat men afleidt uit skt. särtha- „karavaan, groep etc.”; chin. (volgens Wilkinson) tonsit „esv. coiffure”: mal. těroṅsit; ojav. sumanasa „tjampaka” $>$ mal. sěměnděrasa. In deze gevallen pleegt men, voorzover mij bekend, van „verbasteringen” (een weinig aanbevelenswaardige term!) te spreken. We houden de mogelijkheid van „blending" natuurlijk in het oog.

Trachten we nu aan de hand van dit relatief uitvoerige materiaal al staat meer dan een variant niet in de woordenboeken, we mogen met gerustheid aannemen, dat ze ook in andere Indonesische talen voorkomen: lexikografen van verscheidene talen hebben deze varianten, die meestal niet in de literatuur en vaak niet in de taal van hogere kringen bekend zijn en waaronder meermalen uitdrukkingen zijn met een kortstondig bestaan, vaak niet opgenomen - ons een oordeel te vormen omtrent de aard van de uitbreidingen, die de langere vormen ten opzichte van de kortere vertonen en van de soort woorden waarmee we hier te maken hebben. Het zou verkeerd zijn, ze alle eender te beschouwen. Er zijn ongetwijfeld gevallen bij, waar een enkele vokaal méér in de langere vorm het best als een incidentele svarabhakti (anaptyktische)-vokaal (Vokalentfaltung) kan worden opgevat (dus als in ned. Uterecht $<$ Utrecht, lat. saeculum $<$ saeclum); er zijn voorbeelden bij van onomatopeeën en dergelijke, waar een langere vorm kan dienen om een meer gerekte, samengestelde of gevariëerde vorm van het geluid uit te drukken. Er zijn echter gevallen van "mots populaires" van variabele gedaante, een in Indonesische talen evenals elders welbekende groep, waarover ik vroeger gehandeld heb ${ }^{1}$ ), en er zijn voorbeelden bij, waarin een uitbreiding van nog andere aard schijnt te zijn. In de laatste groepen en in een deel van de eerste twee hebben we, naar het mij wil voorkomen, voor ons Maleise tegenhangers van wat men elders „Streckformen” heeft genoemd. Het eerst schijnt De Bo, de auteur van het Westvlaams Idioticon $^{2}$ ), dergelijke woorden te hebben opgemerkt, althans van zijn aandacht er voor in een publicatie blijk gegeven. Hij noemde ze

1) Bijdragen, 99, p. 461 vlgg.

2) Gent 1892; zie vooral p. 281. 
„vormen met een lasch" (dus met een invoegsel of inzetsel), en vermeldde o.a. ned. krawijten naast krijten, klabotsen naast klotsen, rinkinken naast rinkelen, vlaams pateuter : peuter ,klein kind”; zo komt in het Gelders-Overijsels voor karnuffeln voor knuffelen. Schröder ${ }^{1}$ ) geeft ongeveer de volgende definitie van zijn term "Streckformen” in Germaanse talen: woorden, die ontstaan zijn door ontwikkeling of willekeurige (d.w.z. niet systematische, niet aan regels gebondene) inlassing van een willekeurige vocaal of van willekeurige vocaal en consonant tussen de aanvangs- en de daarop volgende consonant of ook tussen de aanvangsconsonant(en) en de vocaal van de eerste syllabe (waarbij het ingevoegde element, ook tegen de accentregels, geen toon heeft). De laatste toevoeging is voor gevallen in Indonesische talen van minder belang dan voor Germaanse. Duitse voorbeelden zijn bv. schmarótzen, schmalotzen „op kosten van anderen leven en zich te goed doen", een woord dat lang voor etymologisch onduidelijk heeft gegolden ${ }^{2}$ ); het treedt in varianten op: smorotzen, smorutzen, alles Streckform bij schmotzen, schmutzen; kalakeln naast kakeln = „gackern”; gramuseln, kramuseln = „krabbeln, kitzeln”, bij gruseln „Schauder empfinden”, bij grusen, grausen.

Een Nederlands voorbeeld is slabakken bij mnl. slakken ,slap worden". Er zijn vele Vlaamse voorbeelden : fladokken, fladakken, flamakken = flokken, flakken (= „laag vleien”); lacháchen (= „lachen”), lambooien $=$ looien, pledómpen $=$ plompen, karnakkelen $=k n a k-$ ken, klavaatsen, waarsch. bij klatsen, kletsen ${ }^{3}$ ) etc. etc. Anderen spreken in dergelijke gevallen van "variations plaisantes": zoo bv. Dauzat $^{4}$ ) naar aanleiding van fr. frimousse ,bekje, bakkesje”, een in de $17 \mathrm{e}$ eeuw optredend woord met nevenvormen frelimouse, phlymouse, phrylelimouse etc. Weer anderen gebruikten de algemene term ,uitbreiding”, „Erweiterung”: deens-noors pladask geldt ${ }^{5}$ ) als ,eine Erweiterung von plask = „klets” ”, een interjectie om het begrip plaske ,plassen, in het water kletsen en derg." aan te duiden; zo ook kladask uit nederduits kladatsch $=$,klatsch" " $)$.

1) H. Schröder, Streckformen (1906).

2) Zie Friedrich Kluge, Etymologisches Wörterbuch der deutschen Sprache ${ }^{8}$, 1915, S. 398.

3) Franck-Van Wijk, Etymologisch woordenboek der Nederlandsche Taal, p. 312 .

$\left.{ }^{4}\right)$ Albert Dauzat, Dictionnaire étymologique de la langue française, 1938, p. 343 .

5) H. S. Falk und A. Torp, Norwegisch-Dänisches Etymologisches Wörterbuch (1911), II, p. 832 , vgl. p. 835 ,

6) Ibidem, p. 525 . 
Het lijkt mij nuttig in te gaan op enige bijzonderheden der Germaanse Streckformen, die vroeger hetzij als composita verklaard werden, hetzij als gevormd met ongewone (,,besondere, sonst nirgends nachweisbare”) suffixen of praefixen (en wel ,dunkle unerklärte und überhaupt auch nicht zu erklärende, weil gar nicht existierende"), hetzij (,unter Annahme der kühnsten Laut- und Bedeutungsübergänge") ${ }^{1}$ ) als leenwoorden, of ook wel als groteske komische vervorming door drinkebroers of soldaten. In de eerste plaats leveren ook hier spreektaal en dialekten de meeste voorbeelden. Als uitbreidende elementen (Streckinfixe) komen voor: vaak $-a b--e b$ en andere combinaties van $a+$ labiaal, speciaal als het woord met $k$, $l, r, s t r, k l, k r$ etc. begint, niet bij labiale, dentale, nasale Anlaut; veel minder vaak $a+$ gutturaal, niet als het woord aanvangt met gutturaal, dentaal; eveneens niet zeer dikwijls $a+$ dentaal, niet bij dentale en nasale Anlaut; wat vaker $a+$ nasaal, behalve als aan het begin dentaal, $l, s+$ vocaal e.a. staan; $a+$ liquida, behalve bij Anlaut met liquida, zelden $a+s(s)$ (Anlaut $k, r, d r$ ) e.a.; ook $a+$ nasaal + cons. komen voor, meestal als ,inwendige genasaleerde" nevenvormen: klambastern naast klabastern ,schmieren; prügeln; mit starkem Geräusch fahren”. „Wo $r$ vor Konsonanten im Streckinfix erscheint, ist es (bes. im Niederdeutschen) nur graphisch und bezeichnet die Kürze des vorhergehenden Vokals" ${ }^{2}$ ). Slechts zelden komen uitbreidende elementen met meer dan één syllabe voor: kladderadatsch bij klatsch, kladatsch; deze zijn alle onomatopoëtisch van aard. Vgl. jav. sumamburat "glinsteren": sěmburat: surat. Opvallend en voor „mots populaires" typerend is het groot aantal "nevenvormen”, de variabiliteit van de woordvorm: karnüffel, karnuffel, karnöffel, karniffel, rabasseln $=$ ramasseln $;$ klabaustern $=$ klapaustern . De vorm van het ingevoegde element is over het algemeen onverschillig; alleen is consequent ongelijkheid van articulatieplaats van de "Streckkonsonant" met de aanvangsconsonant gehandhaafd; volgens Schröder een gevolg van dissimilatietendenzen.

In semantisch opzicht schijnt er geen betrekking tussen de klankvorm van het uitbreidende element en de betekenis van de Streckform of de niet-uitgebreide vorm te bestaan. Slechts zelden wijkt een Streckform in betekenis van de niet-uitgebreide vorm af, en indien wel, dan toch slechts weinig en in een richting, die de grondvorm ook

1) Schröder, o.c., p. 7.

2) Schröder, o.c., p. 242. 
had kunnen inslaan. Hetzelfde constateren we bij de hierboven opgesomde Indonesische vormen. „Nur der Klang, die Färbung wird (bij deze Germaanse woorden) durch das Infix verändert, entweder in scherzhafter oder in verächtlicher Richtung, und schallnachahmende Worte erhalten durch das Infix außerdem eine intensive und iterative Geltung" ${ }^{1}$ ). De betekenissen dezer gerekte woorden variëren zeer, maar twee kategorieën springen naar voren, die welke' in de eerste plaats een geluid, geruis, en dan ook een met geruis of drukte gepaard gaand handelen of gebeuren aanduiden, en die welke (meestal) belachelijke of verachtelijke eigenschappen, personen, zaken, handelingen, schertsend, spottend, schimpend, scheldend benoemen; tot een van deze semantische kategorieën behoort een Streckform, soms tot beide. Meer in detail: interjecties voor geluiden van vallende of geworpen lichamen, het uitgieten van vloeistoffen; woorden voor geluiden, voor veel, luid, zinneloos, weinig gearticuleerd spreken, kletsen (du. klawatschen, plappapper); luid schreeuwen, pochen, twisten (rabastern, krakelen, krakeelen) ; haastig, lawaaiig, oppervlakkig arbeiden; snel, kletsend door het straatvuil, lawaaiig gaan of rijden; wirwar, oude rommel, lawaai (rabuse, karsumpel); slaan, stoten etc.; schofferen, geslachtsgemeenschap hebben, vrouwelijk geslachtsdeel; zich vuil maken; krabbelen, kittelen, kruipen, iemand bij de kraag pakken; verkwisten, brassen; slecht werken, boemelen, straatslijpen, slenteren; op verachtelijke of misdadige wijze leven, op kosten van anderen leven, bedriegen, stelen etc.; knorrig, onaangenaam zijn; overtollige beleefdheden etc.; spot-, scheldnamen voor manlijke en vrouwelijke personen; vissen, planten, vruchten; dranken en spijzen; (lange, wijde, flodderende kleren); gering huis, vertrek, hut en derg.; kaartspel, diarrhee, lantaarn. Een bonte opsomming, maar met merkwaardige punten van overeenstemming met de betekenissen der in dit opstel behandelde Indonesische woorden! Het is zeer te betreuren, dat de lexika geen samenhangende stukjes verhaal of gesprek opgeven, waaruit de sfeer, waarin dergelijke woorden gebruikt worden, of een spottende, scheldende, schertsende toon zou blijken.

Wat de oorsprong van de lasvormen ${ }^{2}$ ) betreft : hier wijst Schröder in de eerste plaats terecht op het bekende verschijnsel, dat zich vooral tussen muta en liquida of nasaal een secundaire vocaal ontwikkelt (svarabhakti) : zo kranzen> karanzen ",met de zweep slaan”, kwet-

1) Schröder, o.c., p. 256.

2) Zoals we ze in navolging van De Bo kunnen noemen. 
sche $>$ kawetsche, kawetsche ,een stuk pruimtabak, dat men uit de mond neemt om het aan een ander te geven" e.a.

In verscheiden dezer vormen heeft zich na de ingeschoven vocaal nog een ,inwendige”, ,spontane" $r$ ontwikkeld: kawetsche $>$ karwetsche, door Schröder, evenals in verleicht <veleicht ,vielleicht", kartholisch < katholsch ,katholisch" uit inverse analogie verklaard, door mij elders ${ }^{\mathbf{1}}$ ) - nader toegelicht.

Gelijk reeds opgemerkt zijn ook Indonesische woorden m.i. op deze wijze te verklaren: mal. cĕrboh> cĕroboh, tĕrjun> tĕrajun, tĕrujun en dergelijke; lampong sardain, gesproken $\operatorname{sarĕdan}^{2}$ ). In het Sasak vindt men naast het 4-syllabige těmĕroko "luchtpijp": těmbroko: staan de $m$ en de liquida in contact, dan ontwikkelt zich ook hier een $b$, als fr. chambre <lat. caměra. Bij de meeste Germaanse Streckformen verschijnt het dan steeds uit vocaal + consonant of vocaal + verbinding van consonanten bestaande "Streckinfix" tussen de aanvangsconsonant en de eerste vocaal: klabastern $<$ klastern. Enige mogelijkheid van verklaring is hier volgens Schröder de hypothese der ,spontane infigering” (m.i. juister „,spontane uitbreiding”), een hypothese, waartegen men, als men andere spontane wijziging van het woorduiterlijk aanneemt, geen principiële bezwaren mag hebben. In verband hiermee zoekt hij de oorsprong der Streckform (hij bedoelt $\mathrm{wel}^{3}$ ) van die met ,spontane infigering”) in de geheime talen (Geheimsprachen), zoals die tegenwoordig bv. nog onder de schooljeugd bestaan: $d u$ bist dumm $>d u$-hulefu bist-histlefist dumm-hummlefumm etc., of eenvoudiger in de Räubersprache van de scholieren te Kiel: labéb wabol $=$ leb wol. Een argument is hem, dat zowel in die geheimtalen als bij de lasvormen een $b$ zeer gaarne uitbreidend element is ${ }^{4}$ ).

Het wil mij voorkomen, dat Schröder deze herkomst nader had moeten toelichten, en dat het, zoals ik binnenkort elders hoop uiteen te zetten ${ }^{5}$ ), waarschijnlijk juister is deze formulering te geven: zoals ook in andere opzichten, zo vertoont ook op dit punt de geheime taal een duidelijke (hier: zeer uitgesproken) neiging tot hypertrofie van wat in de algemene taal leeft en mogelijk is; over de lagere klassen

1) Bijdragen 101, bl. 162 vlgg.

2) H. N. van der Tuuk, T. B. G. 18 , p. 126,132 vlg.

3) Vgl. § 353 (p. 259), begin.

4) Schröder, o.c., p. 256 vlg. Zie ook A. Nicéforo, Le Génie de l'Argot (1912), p. 167; R. Lasch, Über Sondersprachen und ihre Entstehung. Mitt. Anthrop. Gesellsch. Wien 37 (1907), p. 94.

5) In een opstel over de variabiliteit van het woordeinde in Indonesische talen. 
der maatschappij kan uit de geheime talen van bevolkingsgroepen die wat te verbergen hadden (misdadigers, kooplieden etc.) het aantal Streckformen, in ruimere kring in gebruik, belangrijke versterking hebben ondervonden. Schröder verliest uit het oog, dat lang niet alle ,geheime taal” (bargoens, dieventaal, kramerstaal, jargon etc.) ,lettertaal" is, dwz. een bewust procédé om het gesprokene voor buitenstaanders geheim te houden door de volgorde der klanken geheel of gedeeltelijk om te draaien, door klanken te verplaatsen of in te las$\operatorname{sen}^{1}$ ). In taal van kinderen, tegenwoordig nog in ,scholierentaal” komt dit veel voor, vroeger ook in geheime verbonden en dergelijke, in moderne tijden ook nog op fabrieken enz. Speelinstinct en zucht tot sociale differentiëring zijn de oorzaak van deze brabbeltaal; ,men wil zich nauw aaneengesloten voelen en daartoe helpt o zoo knusjes een eigen geheime taal" ${ }^{2}$ ). De sociale nood van bepaalde groepen, die tot afzondering en verdediging ook in de taal dwingt, is, betoogt Moormann, wel de generale oorzaak. Sommige ,lettertaal”-woorden zijn in de andere geheime talen overgegaan, zo in het bargoens van Weert bradiek „,broek”, badichel ,,bochel”, madikel „mokkel”. Het aantal lettertaalelementen in de Nederlandse geheime talen is echter gering. Het wil mij dus onwaarschijnlijk voorkomen, dat Schröder zonder meer gelijk heeft met zijn opvatting omtrent de herkomst der lasvormen. Er mogen gevallen bij zijn, waar hij het rechte treft, een groot deel zal zijn oorsprong hebben in een zekere zucht tot woordverandering, tot uitbreiden en voller doen klinken, en daardoor ook in een tendenz tot een zekere klanksymboliek. Een argument tegen de hypothese van Schröder als enige verklaring (afgezien van de onomatopeeën en praeduplicatieve woorden) zou zijn (maar dit punt verdient een nader onderzoek), als klankverwisseling en -verplaatsing, die evenzeer in de lettertalen voorkomen (omkering van éénsyllabige woorden, type: peter $>$ retep, type eilen $>$ leien) met dit procédé niet of nauwelijks gepaard zou gaan. Tegen het aannemen van herkomst dezer woorden uit een geheime taal schijnt mij vooral te spreken, dat het hier woorden betreft, die in het algemeen in geheime talen niet voorkomen, woorden waarbij geen sociale aanleiding tot verandering is. In het bargoens zijn bv. de geheime elementen niet meer dan \pm 220 à 300 woorden per persoon ${ }^{3}$ ), en dat wel woor-

1) Bijzonderheden bij J. G. M. Moormann, Diss. Nijmegen 1932, p. 14 vlg. en 125 vlgg.

2) J. van Ginneken, Handboek der Nederlandsche Taal I, 379.

3) Moormann, o.c., p. 36 vlgg. 
den, die begrippen uitdrukken, die samenhangen met het beroep, de geheimen, etc. van den spreker en zijn partner, woorden die niet door buitenstaanders gehoord mogen worden. In de dievetaal ${ }^{1}$ ) vindt men zeer veel ,vervangingswoorden” voor al wat met diefstal, geld, politie, gerecht, inbraak etc. samenhangt. Voor deze begrippen zijn soms zeer veel termen aanwezig: in de dievetaal der Hollandse steden zijn 46 woorden voor agent en rechter. In het jargon der veehandelaren, een geheime vaktaal, hebben de geheimtaalwoorden voor een groot deel betrekking op handel en de koopwaar dezer lieden ${ }^{2}$ ) enz. Over het algemeen vallen de Streckformen en de in dit opstel behandelde Indonesische termen buiten deze kategorieën. Evenals bij ons de schoolklas, de huiskamer, de vriendengroep woorden vormt en vervormt, zal ook (hier dient een onderzoek naar te worden gedaan) de Indonesische dorps- of familiegemeenschap, het kleine sociale milieu ${ }^{3}$ ) een gunstige sfeer zijn voor dergelijke woordveranderingen, die hier niet ten doel hebben geheimhouding van voor spreker en hoorder belangrijke begrippen, maar affectieve, klanksymbolische nuancering om te schertsen, te spotten, nader te kenschetsen of te onderscheiden; om een meer adaequate uitdrukking voor een bepaald begrip of proces te geven, een meer expressieve, emotionele uiting te vormen, of ook zonder deze redenen, om een woord wat uit te breiden, - men noeme het speelsheid. Ook ten onzent heeft een langere woordvorm, hoe zijn verhouding tot de kortere ook is (volksetymologische verbinding, langer suffix) wel een affectief-intensieve waarde: luxurieus : luxueus; zaggerijnig: chagrijnig. Spottend: ouvèrier is te Parijs een "prononciation emphatique et ironique pour ouvrier" 4).

In sommige gevallen kan een andere aanleiding bestaan hebben tot het uitbreiden van woorden, $\mathrm{nl}$. het bekende verschijnsel van woordtaboe of taal-pantang: men spreekt een woord dat een magisch gevaarlijk begrip aanduidt niet uit, vervangt het of wijzigt het. Tegenover mal. kuku ,nagel, klauw, hoef" staat mak. boeg. kanuku, koelawi kanupa, napoe kandupa, parigi kalupa, bare'e kayupa ; Adriani ${ }^{5}$ ) vermoedt in de woorden met $p$ een stam *kupa, mal. kupas ,schillen, pellen, onthuiden"; men kan er evenwel op wijzen, dat woorden voor "nagel" ook in Indogerm. talen, hoewel zonder twijfel onderling sa-

1) Ibidem, p. 61.

2) Ibidem, p. 85 vlgg.

3) Vgl. ook Nicéforo, o.c., pp. 104-200.

4) L. Sainéan, Le langage parisien au XIXe siècle, p. 100, zie ook de noot: „Dans l'Anjou, les paysans désignent par dérision l'ouvrier des villes par ovériau”.

5) N. Adriani, Bare'e-Nederlandsch Woordenboek, p. 239. 
menhangend, verschillen vertonen, die niet overeenkomen met de

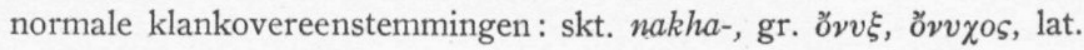
unguis, lit. nàgùtis, ohd. nagal, etc.

Deze inwendige verlenging in de Indonesische talen schijnt derhalve tot dusver niet van de infigering onderscheiden te zijn. Adriani bv. spreekt in zijn Sangirese Spraakkunst ${ }^{1}$ ) wel over woordvorm, over verlenging en verkorting van woorden, maar niet over. inwendige uitbreiding. Evenmin in zijn Bare'e-Spraakkunst ${ }^{2}$ ), des te opvallender daar hij wel, volkomen terecht, opmerkt, dat er woorden zijn, die ,door voorvoeging eener lettergreep, die niet tot de eigenlijke prefixen kan gerekend worden", uitgebreid worden. Ook onder de ,doubletten en tripletten" ${ }^{3}$ ), waar ze vermeld hadden kunnen worden, noemt hij de Streckformen niet. Wel spreekt ${ }^{4}$ ) hij over „gemaakte woorden”: „In verontwaardiging of scherts worden vaak woorden gevormd, die voor het eerste gedeelte termen zijn welke men in gewone gemoedsstemming gebruikt, maar verder bestaan uit een woord, dat toespeling maakt op een scheldwoord, een verwensching of een bedreiging. In het algemeen staan zulke woorden buiten de taal, maar enkele vormingen van dien aard zijn toch zoo gebruikelijk geworden, dat ze tot de gewone termen zijn gaan behooren."

Over een type van woorden met inwendige uitbreiding in het Javaans heeft evenwel Poensen ${ }^{5}$ ) een vrij uitvoerige opmerking gemaakt: „Ook is de beteekenis van den frequentatief onderscheiden van die, welke een woord krijgt door de verdubbeling der middelste aksara waaruit eenige tweelettergrepige woorden met gesloten eindlettergreep bestaan. Bijv. suwarwak ,een grote scheur hebben” van suwak „(af)-gescheurd”; cěluluk ,door geroep of geluid geven zijn aanwezigheid ergens openbaren of te kennen geven”: cěluk ,geroep, (aanhoudend) toeroepen”; cěninak ,met uitgestrekte hals (ergens over heen zien etc.)": cinak ,verwonderd opkijken”; (mak) cěnainuk ,teleurgesteld (moeten) blijven staan kijken (doordat men niet aantreft wat men verwacht)" (Pigeaud), ,uitstrekken van de hals om iets van naderbij te zien” (Gericke en Roorda) : camuk „,iemand die ergens geplaatst is om iets van verre gade te slaan”; njěriènè $k$,(lig-

1) N. Adriani, Sangireesche Spraakkunst, hfdst. II.

2) N. Adriani, Spraakkunst der Bare'e taal, V. B. G. 70, § 8, p. 32.

3) Ibidem, § 16.

4) Ibidem, § 17 .

5) C. Poensen, Grammatica der Javaansche Taal, (1897), § 106, p. 134. De betekenissen zijn door mij toegevoegd. 
gende, zittende, lopende) het hoofd (de kop, even) oplichten (om te kijken enz.)": njënèk ,het hoofd achterover houden". (G. R.; Pigeaud: njènék); buwèzè̀k: buwèk ,gapend open (gescheurd)"; prěniniis bij prinis ,grijnzend de mond vertrekken" van pinis (vgl. voorts bv. nog njĕnigingis „(er) vervallen (uitzien)”; (patïn) cěnè̀ं̀̀s „,steeds maar verlegen grijnzen”). En dit laatste voorbeeld doet wel zien, dat de verdubbeling der midden-aksara eene andere beteekenis moet hebben dan de frequentatief, want prinis heeft al reeds de beteekenis van een frequentatief door een ingeschoven $r$... (het) blijkt, dat die verdubbeling der midden-aksara de beteekenis van: het blijvende, het aanhoudende zonder opeenvolging, vervanging, of rust tusschen de herhaalde handeling, het onafgebrokene dus, aan zulk een woord toevoegt, Op deze wijze zijn waarschijnlijk eenige woorden gevormd, die nu als stamwoorden beschouwd worden, wijl de woorden, waarvan zij gevormd werden, niet in gebruik schijnen te zijn. Bijv. : cěkikik ,gelach met ingehouden stem met hi-hi!”, cěkakak „,schateren van het lachen”; írěpèpèh „,kruipend, nederig gebogen”; biyayak ,onbestemd ronddwalen”; nayuyus ,in de regen op weg zijn”; (mbiyayah ,rommelig” etc.)”.

Ook dit type heeft zijn tegenhangers onder de Streckformen in andere taalfamilies: het zijn de zg. praeduplicatieve woorden (pr. Streckformen) ; Duitse voorbeelden zijn : rambambsen ,,volstoppen”, runkunkel „gerimpelde vrouw”; humpumpen „hinken”; Nederlandse slampamper, reduplicatieve formatie bij slampen (Kiliaen), waarnaast slempen $\left.{ }^{1}\right)$,-rinkinken $\left.{ }^{2}\right)$.” $\mathrm{Daß}$ auch ... die Präduplikationsformen (naast de ontwikkelingen uit svarabhakti) nicht aus den Geheimsprachen stammen, sondern einer durch Zufall (vielleicht als Stotterform) entstandenen Bildung und dann analogischer Schöpfung ihr dasein verdanken mag, gebe ich zu, ja halte ich bei manchen Worten dieser Gruppe für wahrscheinlich", zegt Schröder ${ }^{3}$ ). De neigingen tot klankspel, tot klanksymbolische adaptatie en tot emotionele intensivering hebben m.i. zeker tot het tot stand komen van dergelijke vormen meegewerkt. In de Archipel bestaan ze ook buiten het Javaans : mal. halilintar, naast halintar ,inslaande bliksem”; sěnènèh „de tanden tonen bij het lachen of grijnzen": sènèh ,met enigszins open mond”; mal. gělakak „hartelijk grinnekend gelach”: gělak „gelach”; tont. rikotkot "gekrabbel": vgl. soend. rèkot "kraken”.

1) Franck-Van Wijk, o.c., p. 613 .

2) ..Onomatop. rijmformatie", ibidem, p. 551.

3) Schröder, o.c., p. 259. 
Thans de woorden, die men sěsěran- en sěsĕlan-woorden kan noemen, die met de dusgenaamde vocaal $+r$ of $l$-infixen. Gaan we eerst het Nieuw-Javaans op dit punt na ${ }^{1}$ ), dan blijkt, dat de spraakkunsten sinds jaar en dag leren wat Roorda ${ }^{2}$ ) als volgt formuleerde: „Door invoeging van ...r of $l$, of ook ... met een pěpět of $a$ er voor, en dus van.... $\breve{e r}$ of $\breve{e l}$, of wel $a r$ of $a l$, achter den eersten medeklinker van het grondwoord zijn in de Javaansche taal een groote menigte woorden gevormd, waarvan de betekenis, behalve den zin van het grondwoord, tevens het denkbeeld van veelvuldigheid in zich sluit; gelijk dit zelfde denkbeeld door dezelfde klanken uitgedrukt wordt in de Hollandsche woorden wapperen, knetteren, schitteren, stotteren, trappelen van trappen, krabbelen van krabben, en vele andere. Dit is de frequentatieve vorm, waardoor beteekend wordt, dat een accident veelvuldig, en dus dikwijls na elkander, op vele plaatsen of overal, of door velen tegelijk, plaats heeft of geschiedt". „Verder wordt, om uit te drukken, dat iets overal, aan alle kanten of aan een menigte voorwerpen tegelijk plaats heeft, het woordje tin...., patin vóór een drielettergrepig woord geplaatst . . . . Maar, als nu het woord, waarvan men dat samengestelde frequentatief, zooals men het noemen kan, vormen wil, slechts uit twee lettergrepen bestaat, dan wordt het drielettergrepig gemaakt door invoeging van ar of $a l$ ". Men geeft als voorbeelden tatab ,kloppen”: taratab „klopping van het hart”; tètès ,druppel”: trètès ,bezet met juwelen”; men merkt op, dat veelal ,de grondvorm zonder die $r$ of $l$ niet in gebruik” (Roorda) of ,niet meer in gebruik” ${ }^{3}$ ) is, bv. crèzèt ,zaniken"; zij doen dienst als grondvorm van afleidingen : mbribèni ,,door veel praten storen".

In vele gevallen zal men tegen de benaming frequentatief geen bezwaar mogen maken, nl. daar waar naast een $r$ of $l$-loze vorm zonder frequentatieve betekenis een met het genoemde element staat, die een zekere herhaling, veelvuldigheid, gelijktijdige veelvuldigheid aanduidt, bv. kampul ${ }^{2}$,bovendrijven”: krampul „op en neer drijven” en in de verbindingen met tï of patin: sin kĕtaton paḍa patï glěrěn „van alle kanten kreunen de gewonden”, intěné patin glěbyar „overal schitteren de juwelen”. Inderdaad geven deze vormen een „overal, aan alle kanten, herhaaldelijk, door meervoudige agens, of samengestelde agens etc. gebeuren van de handeling" aan.

1) Enkele Maleise gevallen zijn boven al opgesomd.

2) T. Roorda, Javaansche Grammatica, (1855), § 197, p. 187; § 198, p. 187 vlg.

3) C. Poensen, Grammatica der Javaansche Taal, (1897), § 105, p. 132. 
Naast deze welbekende en in alle spraakkunsten behandelde vormen zijn er echter ook andere, waaraan men minder aandacht heeft besteed. In de spraakkunsten heb ik er niets over ontmoet, in de verdere literatuur slechts een opmerking van $\mathrm{Wulff}^{1}$ ), die er op wees, dat $l$ (hij spreekt van $l$-infix) in de tweede syllabe van het grondwoord niet zeldzaam is, bv. mal. sěnkan ,wat tussen twee voorwerpen wordt aangebracht om ze uiteen te houden": sělěnikan „dwarsbalk, sluitboom”; sěnikĕlaì „id.”; sělěnikat: sěnkĕlit „strop, waarmee men in bomen klimt" etc., en dan ook batav. kĕpak, kĕlěpak, kĕplak onom. voor bepaalde kleppende, slaande, kletsende geluiden. Wanneer Dempwolff de woordvorming van de Indonesische talen behandelt ${ }^{2}$ ), zegt hij, dat de meeste „Wortstämme” van het type lainit (cons., voc., cons., voc., cons.) zijn, dat daarnaast grondwoorden van het type sunson voorkomen, dat er bovendien nog woorden met meer dan twee of met een syllabe bestaan. Waaraan hij dan toevoegt, dat men ,neben der lebendigen Verwendung der Formantien .... auch vielfach ,erstarrte” Formantien findet." Brandstetter ${ }^{3}$ ) komt tot de conclusie, dat het Indonesisch in het inwendige van een woord slechts twee consonanten duldt, wanneer dit zijn explosief voorafgegaan door homorgane nasaal, of (wanneer het grondwoord bestaat uit de geredupliceerde wortel) slot- + aanvangsconsonant van het wortelelement. Merkwaardigerwijze noemt hij noch het frequente type terrbit (inwendig $r$, soms $l+$ cons. $\left.)^{4}\right)$, noch de eveneens, althans in het Javaans talrijke woorden van het type jav. gograg ,door elkaar geschud", soend. jëpluk „vooruitspringen”, waarin zich dus inwendig cons. $+r$ of $l$ bevinden. Soms bestaan er naast deze vormen geen kortere, zonder $r$ of $l$ (of, voorzichtiger gezegd, deze worden niet opgegeven), bv. jav. gograg; gogrog „(ontijdig) afvallen (van knoppen, vruchten etc.)”; goglog (grof) „opgevreten”, ñomron (gewest. spreekt.) „slordig, lelijk”, ñokrom (gewest.) ,afhangend, overschaduwend". Soms is dit echter wel het geval: jav. gěbug (gewest.) „stok, afranselen”: gěbrug „fijngestampt, ingestampt”, gěblug (gewest.) ,murw geslagen, uitgeklopt”; gěbag (dienst doende als krama bij gěbug) „slaag krijgen”: gěbrag „bonzen" ${ }^{5}$. Om het meteen te vermelden, ook de consonant-combi-

1) K. Wulff, Z. D. M. G. 62 , p. 687 , n. 1 .

2) O. Dempwolff, Vergleichende Lautlehre des austronesischen Wortschatzes I (1934), § 17, p. 27 vlg.; § 18 d, p. 29.

3) R. Brandstetter, Gemeinindonesisch und Urindonesisch (1911), §§ 55-60.

4) Zie Bijdragen 101, p. 163 vlg.

5) Het komt ook wel voor, dat de kortere vorm juist de occlusief mist : sélak „ontkennen”; séblak (gewest.), „idem”; hiernaast ook sènklak (gewest.) „idem”. 
natie occlusief, voorafgegaan door homorgane nasaal en gevolgd door $r$ of $l$ komt meermalen voor : jav. țankrin, țaikkrón (gewest.) „(van een vogel op een tak enz.) hoog zitten op”; tambla $\dot{n}^{2}$,vol vlekken”, tamblèg „onverschillig, gehard”, cimpli, cimplik, cimplin (gewest.) „kTein oliepitje”. Soms ook $s+$ cons. + liquida : jav. cěsplěn் „uitnemend helpend".

Laten we éens een aantal dezer Javaanse gěbrug-woorden de revue laten passeren: bablas ,eensklaps uit het gezicht verdwenen; er van door" (vgl. babas, gewest. ,doorgaan, onmiddellijk daarna”?) ; mbabrag „vol jeugdige kracht (man, dier)”; babragan „keukenrek”; mbabrah „zich uitbreiden (zaken, bezit)"; mbabrak „(steeds verder) opengaan of -scheuren (wond, scheur)": babak ,geschaafd, ontveld”; babral (gewest.) „afgesneden”; bandrèk „overspelig”; (m)bandrěn் „steeds door volhardend”; bandrin (gewest.) „steenslinger”; bainkrah „rommel, kapot en waardeloos"; (m)baikkrĕn (gewest.) ,ijverig (over zijn werk gebogen)”, (m)bainkrun ,doorgebogen (rug), krom”; běblěk (spreekt.) ,in groten getale aanwezig”, běblěs ,,verzinken”, mbèbrèk „zich (langzamerhand) ten nadele van iets anders uitbreiden (scheur, wond, brand e.a.)"; mbèbrèl (gewest.) „onsolide; kletsen”; mbèbrèt „luide winden laten”; mbebret „,doorgesleten, scheuren krijgen”; (drie-

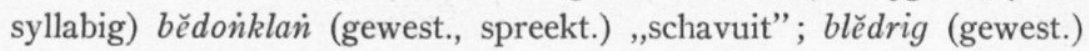
„,nazetten”: blědig „,idem”; mblotron, „buikig uitgezakt”: mbloton (gewest.) „,idem”; bunkrah (gewest. spreekt.) „opengebroken”; bunkrèkan (spreekt.) „schurftig”; bunikrèk (gewest.) ,esv. perskoek”; bunkrinan (gewest.) „klein, schraal blijven”: buinkin (gewest.) „,schraal”; bunkruh (gewest. spreekt.) „mager en zwak, verarmd”; mbuikkrun (spreekt.) „krom (rug)”; buncritěn (gewest.) ,schraal er bij staan"; mbombron "nog geen toilet gemaakt hebbende"; mbondran்-bandrěnaké (spreekt.) „steeds maar door laten gaan”; mbonjrot (spreekt.) „(vrij) dun eruit vloeien”; dablag ,zeer grof bamboevlechtsel ; mazelen”: dabag „,idem”; ndablag (spreekt.) ,,vol (mensen) zitten": ndabag; dablain "breed terzijde uitstaande"; $(n) d a^{-}$ blĕg (grof) „,alles aan zijn laars lappen”; nḍabrĕg (spreekt.) „een heleboel”; nḍglo (gewest.) „werkeloos blijven zitten”; ḍagrèg (gewest. spreekt.) „oud en onbruikbaar”; damplak of $\boldsymbol{d}^{2}{ }^{2}$ (gewest.) ,goed breed uitgegroeid (van horens)”; damplèn (gewest. grof) „,zoals iemand er uit ziet”; danglonian (gewest.) „rare kuren hebben”; ḍanklak-ḍanklik, dě̀iklak ,(kunnen) doorknikken (van de gewrichten”, $n$ dainkruk (spreekt.) ,ergens op of tegen zitten (voorover gehurkt)”; nḍaplan ,"met uitgebreide armen (in de weg) staan”; ndéblag (spreekt.)

D1. 102. 
„(verbazend) stevig eruit zien”; ndeblèg (spreekt.) „(verbazend) vol, dik erop zitten"; dèblèn(an) (spreekt.) ,,achterwaarts uitstaan (horens etc.)”; dĕdrĕg ,(het vechten) niet willen opgeven”; deglèg ${ }^{2}$,,rammelen (machine)”, déglog, d̆ĕglag, dĕglug „kreupel lopen; knikkebollen”; ndẹ̆glin ,,met een doorbuigende knie”; dĕgrès (gewest., spreekt.) „,half idioot”; ndĕgrus (id.) „maar blijven zitten (niets doen)”; d̦ěmblèk (id.) „dicht tegen elkaar zitten”; ndémblo „dicht er op zitten (blanketsel)"; đ̆ěmplah ${ }^{2}$,aan lappen er bij hangen”; d̦èmplan (gewest.) „21/2 cent(stuk)”; ndèmplèk (gewest. spreekt.) ,tegen iemand of iets

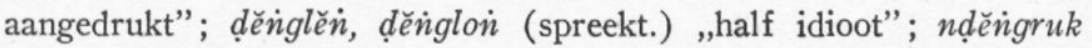
(gewest.) ,lang blijven zitten”; děnklak (gewest. grof) ,oude sukkel”: dĕikak (id.) „,idem”; dériklak-ḍénkluk (spreekt.) „,het hoofd laten

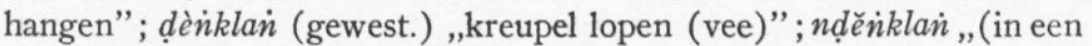
fraaie boog) doorbuigend (arm, hand)”; dèǹklè ${ }^{2}$,er slap bij hangen”; nḍ̀̀nklèk (gewest.) „hinkelen”; nḍènklèk ,,ver achterover doorbuigen

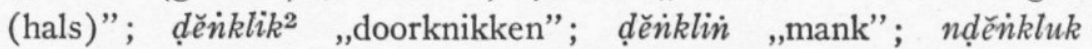
(spreekt.) „het hoofd diep voorover buigen”; déplak-ḍeplèk „,tegen iets aanhangen (zittende, hulp zoekende etc.)”; dẹplok „fijn gestampt”; ndéprok ,zich zomaar ergens laten neervallen (van verdriet of vermoeidheid)"; dïnklan (gewest.) ,,kreupel (lopen)”; diinklik ,zitbankje”; ndiinkluk (gewest.) „hoofd en schouders diep voorover buigen”; jablas (gewest. spreekt.) ,plotseling weg zijn”; njablog (gewest.) ,,vreten”; njabris, njabrut (spreekt.) ,een zuur gezicht zetten”; jagrag „schraag”; jamblan „,esv. vrucht”; njamblik (gewest.) „vlak bij liggen”; jamprah (gewest.) „met een lange volle haarbos of staart”; jamprit „zwierig (van uiterlijk)”; janjras (gewest. spreekt.) „(er)

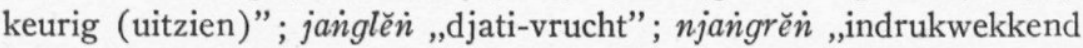
(groot)”; jaingrun „(opmerkelijk) groot en fors”; jaingruñan „optreden van een dansvrouw met muziek, 's nachts"; jankkrak (gewest.) ,(met een) voornaam (voorkomen)"; jaikrik ,esv. krekel”; njantrun (gewest. spreekt.) „,stil (blijven) staan (niets doen)”, njaplak (gewest.) „,wijd uitstaan (hoofddoek)”; njaprèt (gewest.) „(met korte) sprieten (gras, haar)"; njěblag „opvallend open (zichtbaar)”; jěblas-jěblès „,bom-bom (van harde slagen)”, jěblas-jĕblus ,deur-in deur-uit”; (wěsi) jèblèkan (gewest.) „plat ijzer”; jèblěs (spreekt.) „precies uitkomen”; jĕblès „(met het hoofd) tegen (de muur) bonzen”; jĕblin (spreekt.) ,floep”; njěblis (grof) „opium schuiven”; njĕblug ,(met een zware knal) ontploffen"; njĕblus (spreekt.) ,uitkomen op": (n)jěbus (gewest. spreekt.) ,idem; doorsteken(de) naar”; jěblog „modderig (weg)”; jĕblon (gewest.) ,ingezakt”; njěblos „openspringen”; jěblos (gewest.) 
„opengelegd”; jěblos ,uitgang”; njěbomblog, njěbombrot (gewest.) „,slordig, ongekleed zitten”; njĕbrag (gewest.) „(met piekerige uiteinden) wijduit staan”; njĕbrèd „met omgekrulde punt (klinknagel) etc.”; jèbrèn (gewest.) ,uitspreiden”; jĕbrèt, jĕbrot (spreekt.) „floep er uit komen”; njěbrig (gewest.) „overeind komen te staan”; patin jěbrïn (spreekt.) ,hier en daar een haartje (op het hoofd)”; njĕbrol (spreekt.) ,vlug te voorschijn komen”; njébrod (gewest.) ,,met goed ontwikkelde heupen”; njěglag (spreekt.) ,(lekker) achterover zitten”; (grof gewest.) ,zitten vreten”; jĕglèg ,klikklakken”; mak jĕglig (spreekt.) ,,boem (ergens tegenaan botsen)”; njĕglig (id.) ,alleen zitten”; njéglug (id.) „mank lopen”; njëglug (id.) „,botsen tegen”; njĕglog (id.) „rustig blijven zitten”; njĕglon „,vol verraderlijke kuilen”; mak jĕgrag „,in eens gestoken (met een piek enz.)”; jégraì (gewest.) „(veel) te kort (van een broek bv.)”; njègrèg (spr.) ,flink recht overeind (komen te staan)”, jègrĕg ,(plotseling) blijven steken”, njĕgrèg ,een klik laten horen (machine)”; njĕgrĕg ,als verlamd en verstomd (blijven staan)”; njĕgrig (zruluné) „(zijn haar) gaat overeind staan”; (ora) jégros (gewest.) „(niet) kunnen”; jĕgros (grof) „(maar) blijven zitten (niets doen)"; njěklèk „knappen”; jěkluk $(i)$ „laten knappen”; jěkrèk ,klem (voor ratten enz.)”; njĕmblan (grof) „,met een dikke buik rondlopen (zwanger zijn)”; jĕmblĕg (gewest.) „,modderig, vuil” = jĕmbĕg; njèmblèk ,vies aan elkaar blijven kleven”; njèmblěm (spreekt.) ,met een vollemaansgezicht dom blijven zitten”; njĕmblěn (gewest.) ,verbaasd staan”, enz. enz.

Het valt bij dit, zeer onvolledige overzicht, waarvoor het materiaal geput is uit het Handwoordenboek van Pigeaud, op, dat er onder deze woorden vele zijn, die dit lexikon met ,gewestelijk" betitelt, dwz. die niet behoren tot de in Soerakarta gangbare taal, waarbij ook te rekenen zijn ,plattelandse” woorden; vele ook die daar tot de ,spreektaal” worden gerekend, dwz. ,woordvormen en uitdrukkingen welke, al vindt men hen ook wel in geschriften, toch meer behoren tot de gemeenzame, huiselijke uitdrukkingswijze en verhaaltrant"; er zijn ook grove termen bij. In een minderheid der gevallen staan er naast de gěbrug- ook gěbug-woorden; soms schijnt er dan een plaatselijk verschil te zijn; zelden is er een verschil in betekenis en duidt het woord met $r$ aan ,,iets blijven of steeds verder iets.... worden”. Wat de semantische kategorieën aangaat, waartoe deze woorden te brengen zijn: allereerst valt op het zeer geringe aantal namen van planten en dieren; ook de gebruiksvoorwerpen zijn slecht vertegen- 
woordigd; soms wordt iets van zeer geringe waarde angeduid ${ }^{1}$ ); onomatopeeën en wat zich daarbij aansluit zijn er meer, doch ook relatief weinig ${ }^{2}$ ); bewegingen, standen, lichaamshoudingen of -vormen, toestanden, en dan wel speciaal die welke van de normale afwijken zijn zeer goed vertegenwoordigd. De hier niet vermelde woorden van dezelfde gedaante hebben overeenkomstige betekenissen.

Van „frequentatieve betekenis”, dwz. van de boven besproken semantische schakeringen is dus weinig sprake, ook al komt wel eens een uitdrukking voor, die daaronder gerekend zou kunnen worden. In uitdrukkingen als patin slambrain ,onbestemd van de ene plaats naar de andere zwerven”, patin slěmbrah (gewest.) ,,aan slierten erbij hangen" is patim met de $l$ in de eerste syllabe te verbinden. Ook een betekenisnuancering als bestaat tussen een paar als sugěn (gewest.) ,trots, hoogmoedig” : sugrěn (id.) ,indrukwekkend groot (of donker, van geboomte)" wijst niet in die richting. De benaming "frequentatief" zou deze groep woorden al heel slecht passen.

$\mathrm{Nu}$ is er echter nog een derde liquidae-groep, nl. die welke in de eerste syllabe van het tweelettergrepige grondwoord de combinatie occlusief $+r$ of $l^{3}$ ) vertoont, zonder dat men aan ,frequentatieve" betekenis herinnerd wordt of behoeft te worden ${ }^{4}$ ). Bv. blabag „plank”, blabar ,touw”, blabukan ,boomschors”, brankal „puin”, brancah ,zedeloos”; dlaìkup (gewest.) ,tijgerval”; dlancan „papier”, dludag,, esv.vlag"; drajak (gewest. spreekt.) ,(rij) paaltje(s)”; dragěm „kastanjebruin (paard)": glabad (gewest.) ,vlies (op vrucht)”; ṅglabèg (id.) „onwillig en lui”; glaḍag (id.) „horizontale bamboe; esv. jachtlans”; glayun (id.) „garf”, glambèr (id.) „halskwab” (bij ngambèr ,bengelen”) ; glati (id.) „esv. vrij klein mes”, glatik „rijstdiefje”; glěběg (gewest.) ,esv. kar met schijfwielen”; glědĕg (id.) „,esv. (etens)kast (of kist)”; glĕga (id.) „(kokos)palmstam”; glěğes (id.) „,bloesem van suikerriet”; ṅglěgut (id.) „vlijtig bezig zijn”; ńglěmbus ,ziekelijk opgezet (lichaam)”; glémpo (gewest.) ,esv. grote (zak)doek”; glěnděm (id.) „(gedroogd) suikerpalmblad”; glèndèr

1) Een woord voor nietswaardige zaken is bv. nog $s(l) a \dot{i} k r a h$ (spreekt.) "rommel".

2) Hoe is een geval als slomprèt < ned. trompet te verklaren; is de $r$ klankexpressief?

3) In hoeverre deze $r$ of $\ell$ vocalisch zijn, dus $\breve{e}$, ĕl gesproken worden, moet $\mathrm{ik}$ hier bij gebrek aan voldoende gegevens in het midden laten. De woordenboeken zijn hier niet consequent; alleen Pigeaud geeft bijna alleen de woordvorm zonder vocaal (wel: balilu naast blilu "onwetend" e.a.).

$\left.{ }^{4}\right)$ Vgl. de opmerking van H. N. Kiliaan, Madoereesche Spraakkunst, § 95 (I, p. 70). 
(id.) „(bamboe)rol”; glěpan (id.), glěpun „meel”; glugu „(kokos)palmstam, -hout”; glugur (gewest.) „draagbalk”; gloța (,,gewest.) ,,slecht begaanbaar pad”; grabag „,eg”; grabah ,grof aardewerk”; graji ,zaag”; gragal (gewest.) ,grof grint”; grago (gewest.) ,esv. kleine garnaal”; graham (gewest.) „kies”; graingai ,gepunte bamboestok”; grasak ,(grof) grintzand”; grĕmis (gewest.), grimis ,,motregen(en)”; grénda „draaiende slijpsteen”; grènèn „klein (weer)haakje”; grènsè̀n (gewest.) ,esv. grote open braadpan”; grěnsěn "(bij iem. opgekomen) levendige begeerte, behoefte (om iets te gaan doen)”; grèpès ,,geheel afgesleten”; grèțèl ,weerhaak”; gribig ,esv. bamboebindwerk”; grimah (gewest.) ,,achtererf”; grinsin „esv. bamboepatroon”; grobag ,,vrachtkar”; grobog ,grote kist”; groboh ,grof (gemaakt)”; grumbyunan (gewest.) ,gezelschap, omgang”; grumbul „kreupelbos, -hout”; (gewest.) ,gehucht”; grumpun ,,een voet (poot) verloren hebben"; gruzerin „,met weggevreten neus”; grogol ,stevig paalwerk”; gronon (gewest.) „,verwend, lastig (jongen)”; grontol ,gekookte maï"; grosok ,grof zand"; growah ,waarvan een groot stuk is afgebroken”; growal ${ }^{2}$, maar ook patin growal ,ruw, bobbelig”; growon ,hol (boom)"; klaban ,esv. vergiftigde duizendpoot”; klabanan ,haarvlecht”; klabar (gewest.) „ondiepte, (zand)bank”; klabět (id.) „,bruingrijs”; klabut (id.) ,,leest, vorm”; klakah (id.) „,(lang) doorgespleten bamboe"; klamad „spinragdraad”; klambi ,jasje”; klambu „muskietennet”; klampok „esv. djamboe”; klanté „esv. bandje”; klarain (gewest.)., ,esv. rode mier”; klaras „dor blad”; klasa „mat”; klawěr ${ }^{2}$,sliert vuiligheid (in water enz.)”; klaw'u „,bruingrijs" (kip enz.); klèdèk (gewest.) ,dansvrouw-zangeres”; klédun ,esv. vruchtboom”; klěkĕt ,,aandrift”; klèlèt „,resten (in de pijp) van gerookte opium”; klěmbuñan „blaas”; klèmbrèh ,laag neerhangen (kain enz.)"; klěmèr (gewest.) ,teer (kind)”; klëmis (gewest. spreekt.) „glad”; klĕmuk ,esv. aarden pot”; klěmpěr (gewest.) ,flauw vallen”; klĕnḍah (gewest.) „kokos(noot)”; klènkam „esv. gouddraad”; klěntik „kokosolie”; klěntit „,clitoris”; klèti (gewest.) „esv. (ijzeren) vechtstok”; klëtin „,(weef)spoel”; klécam-klècěm „een (blijde) glimlach op het gezicht krijgen”; klěcin (gewest.) ,scherp en vies ruiken”; klétot (id.) „verkeerd”; kléwain „esv. korte sabel”; kliyan „dor blad”; kliyus (gewest.) „schuw”; klika „bast”; klilip "vuiltje in het oog”; klukuk ,watertabakspijp"; klucèh ,glansloos"; kluzuri ,regenboog; spin”; klopod ,smerig”; krabu (gewest. spreekt.) „oorbel”, krakab „,overtrek (over zadel enz.)”; krakad „esv. groot sleepnet”; krakah (gewest.) „erf met tuin”; krakal "grof grint”; 
kranjaì „esv. mand”; kranran (gewest.) „esv. boommier”; krapa (id.) ,vissersknecht”; krĕdan (id.) ,halsstuk van slachtdier” (= kĕrdan, kěrĕdan), krěgěn (id.) „uitgeput”; krèyèn (id.) „vuilnisbak”; (grof) „hoer”; krěnḍi „esv. hert”; krěněn „esv. mandje”; krï̌ӗt „zweet”; krobonian, ,esv. slaapvertrekje”; kruma ,esv. ringworm (huidziekte)”; kroyok (gewest.) ,bandiet etc.”; kropos „(vrij) leeg van binnen”; mlați ,esv. jasmijn”; mlèdèh (gewest.) ,laf, smakeloos”; mlènyèh ,,met vochtige huiduitslag"; mlěntus ,,bol en gevuld”; mlicat, mlicèt ,geschaafd (v. d. huid)”, mliwis ,esv. wild eendje”; mlowa „esv. vruchtboom”; mrangi ,maker van houten krisscheden”; mrèdèh (gewest.) „onhandelbaar”; mrěki ,(id.) roos (in het haar); kippevlo”; mrĕněs ,,gitzwart”; mrěnguk „knorrig en ontevreden”; mrènkèl (gewest.) „koppig volhouden”; mrěnyĕn (spreekt.) „keurig netjes (gekleed)”; mrěnțil (id.) „hobbelig, knobbelig”; mrěpěg (gewest.) „brokkelig”; mriyi (id. + spreekt.) „klein en zwakjes (gewas)"; mriyĕm ,kanon”; mrinin ,met half open ogen (slapen, vrl. v. kinderen)”; mrinis ,,zuur grijnzen”; mrusul (spreekt.) ,,grappig-ondeugend”; ṅlayub „flets staan (ogen)"; planțasan (spreekt.) „kaal geschoren”; planca (gewest.) ,slaapbank”; plancoh (id.) „,in de grond vastgezette staak”; plěkat (id.) "plein”; plumpun, prumpun „,izabel (paard)”; sintru (gewest.) „kamerscherm”: slintru ,id.”; tlabun (id.) ,esv. hakmes”; tlalé „slurf”; tlawah „trog, kribbe”; tlěmbuk (grof) „snol”; tlěcěr „staak”; trabas „poreus”. Enz. enz.

$\mathrm{Nu}$ mogen sommigen met meer of minder recht in de $r$ of $l$ van meer dan een dezer woorden de frequentatief-liquida willen zien, men zal toch moeite hebben, als men al deze termen voor gebruiksen andere voorwerpen, eigenschappen, kleuren, delen van het lichaam, personen, dieren, delen van planten, verschijningsvormen, kledingstukken, ruimtelijke grootheden enz. zo zou willen verklaren. Klanksymbolische woorden en dergelijke zijn er zeker bij; vgl. nog gloglakglogok ,klokken (vloeistof uit fles)”; glorok ${ }^{2}$ „,snorken”; grěngěrian ,gebrom (van menigte), geraas (van wind e.a.)"; gropak ,krak (doorgebroken)"; klènkènan ,janken (hond)"; klikik ,giechelen”; klukak-klukuk, ,klokken (water in fles, gerommel in de buik etc.)”. Opvallend is het grote aantal, dat tot "gewestelijke" of spreektaal behoort. Over het algemeen zijn het termen die tot de woordenschat van weinig ontwikkelden gerekend mogen worden.

Er zijn verscheiden paren, waaraan het ene lid de liquida niet, het

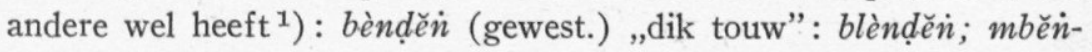

1) R. A. Kern, Bijdragen 102, p. 299 noemt de $r$-woorden ,sterke vormen”. 
$k u k$ „(voorover) gebogen, krom”: mblěṅkuk „krom zitten”; ndělěs (gewest.) „zich stilletjes uit de voeten maken”: ndlělěs (gewest. spreekt.) „,spoedig geheel weg, op (raken)"; ndodor (spreekt.) „koppig, vasthoudend”: ndlodor (id.) „koppig en onbeschoft”; didis ,naar ongedierte zoeken, luizen, pluizen": ndridis ,naar allerlei (kleinigheden) snuffelen”; děnki (gewest.) ,een ander niets gunnen": drěniki ,afgunstig; gemeen”; nḍěsĕl ,zich ergens tussen trachten te dringen”: ndrěsĕl ,zich ergens indringen”; jaburan ,,soorten versnaperingen”: jlaburan (gewest.) ,idem”; jogan ,lager deel van een vloer (in huis)”: jrogjrogan (gewest.) „voorhuis”; gapyak ,gezellig”: grapyak „(als gastheer) gezellig weten te praten”; génjor ${ }^{2}$, ,lillig week”: glénjor ${ }^{2}$ „slap, slodderig”; gétot (spreekt.) „scheef (gaan, bespreking)": gléttot (gewest. id.) ,idem"; gigir (gewest., verouderd) „,rug”: $\dot{n g l i g i r}$, ,(als) met een richel (striem etc., opgezet te voorschijn komen uit een vlak)"; gobag-gabig ,de kop heen en weer schudden (vee)"; globagan (gewest.) ,zich op de grond wentelen (paard)"; kombor ,wijd (vrl. van een broek)"; glombor (spreekt.) „(te) wijd (kleding)"; gontor ,doorgespoeld (met water)": glontor (gewest.) „door -, afgespoeld”; gagap ,,in het donker tasten”: gragap (gewest.) ,idem”; gangam (gewest. verouderd) „aarzelen”: ingrangam (id.) „idem”; gěmbĕl (gewest.) „,vol vruchten (boom)”: ingrěmběl (veroud.) „met dicht gebladerte (bosje)”; gita (-gita) (gewest. veroud.) ,gejaagd, in opwinding”: grita-gritu (veroud.) ,id.”; goḍ̌n, godĕm (gewest.) „21/2-cent-stuk”: groděn (id.) (vgl. Pigeaud, s.v. gorden); goingain „(pas ontstane, gemaakte kleine) tussenruimte”: gróngan (veroud.) ,uit elkaar geschoven”; gaběs ,sponsachtig saploos van vrucht": klapěs ${ }^{2}$ (spreekt.) ,sponsachtig”; gĕnḍok (veroud.) „,esv. aarden pot (voor water of rijst)”: klĕndok (gewest.) „esv. kookpot”: klĕndak (id.) ,esv. waterpot”; kĕmbroh „,kletsnat (geregend etc.)": klěpoh, klěproh (gewest. spreekt.) „nat geworden (kleren, door regen)"; kojon ,esv. vliegengordijn over slaapplaats van kind”: kroḍon (baji) „idem”; $m i(n) t i^{2}$ (spreekt.) „lekker rond (v. buikje v. kind)" : mlèți (id.) ,een dik buikje krijgen, hebben; zwanger worden"; (gewest. veroud.) pupug: „afbreken”; mrupug (gewest.) „,brokkelig (houtwerk)”; pugěs (gewest. veroud.) „tot de grond afgesneden”: prugus „kaalgevreten (gras etc.)” (ook progos); (ojav.) pěsat „,wegspringen” : plěsat ,ineens w.”; sakan் (gewest. ver-

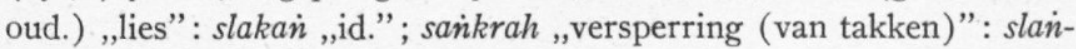
krah „rommel”; silěp ,geheel onder water verdwijnen”: slělěp (gewest. spreekt.) „,idem”; sudah (gewest. veroud.) „uitgepakt”; sludah 
(veroud.) „volop onthalen”; sumbati (gewest.) ,afgestoken (vezelbast van kokosnoot) met een puntige stok": slumbat ,die stok"; suba „overladen (met beleefdheden)": $s r u b a^{2}$ (gewest.) „idem"; naast mal. tainkas „vlug”: tlankas (gewest. veroud.) „vlug, flink”; tapak „voetstap, spoor”: tlapakan „(voet-, schoen-) zool”; tèdès (gewest.) : tlèdès ,geheel uitgeput”; tépak (gewest.) „esv. houten sirihdoos”: tlépak (id.) „idem”, ook lépak (gewest.) komt voor; tètèh „,duidelijk”: tlètèh „duidelijk verhaal(d)"; titik „nauwkeurig beschouwen”: tlitik (veroud.) „idem”; tisik „stop (in kleren)”; tlisik (spreekt.) „stoppen”, trisik (id.) ,idem”, topoin „kroon (van wajangpoppen)": tropon „kroon”.

Ook van deze, voor uitbreiding vatbare, lijst zijn zeer vele woorden spreektaal en buiten het toonaangevende Solo'se milieu in gebruik; ze behoren weer tot de copia verborum van den gewonen man. Ook hier zou men soms aan ,frequentatieven” kunnen denken, maar in verscheiden gevallen is dit m.i. volkomen onmogelijk ${ }^{1}$ ).

Voorts valt op te merken, dat naast dergelijke disyllaba ook bij Pigeaud trisyllaba verschijnen: naast tlèdèk „dansvrouw”: talèdèk. Interessant is in de bovenstaande lijst van doubletten, dat er meermalen een semantische differentiatie tussen beide leden van het paar bestaat. Deze differentiatie kan ver gegaan zijn. Pigeaud meent bv. onder mblancèr naar mbancèr te moeten verwijzen; het eerste (gewest.) betekent „mooi, flink (van een jongen man)", het tweede (id.) ,met een dansvrouw gaan dansen”; zo verbindt hij ook mrěnțěl „krullend (haar, stengel)” met měntěl ,flink wat (geld) bij elkaar hebben" (hier ontgaat het semantische verband mij ten enenmale, vergissing?).

Iedere gedachte aan frequentatieven in de strikte zin des woords, gevormd met de „frequentatief-infixen” $-a l$-, $-a r$ - etc. moet, dunkt mij, verdwijnen, wanneer we ons herinneren, dat er ook talrijke woorden in het Javaans zijn (zij het veel minder talrijke dan de $r$ - of $l$ woorden), die op dezelfde plaats een $y$ of soms ook $w$ vertonen. Ook hier vinden we deze consonanten in de eerste en in de tweede syllabe ${ }^{2}$ ). Voorbeelden (leenwoorden buiten beschouwing gelaten):

1) Pigeaud, Javaans-Nederlands Handwoordenboek, p. IV „Zo heb ik tot de spreektaal-woorden gerekend o.a. vele van de overtalrijke woorden, vaak gevormd door middel van de invoegsels $-(a) l-,-(a) r$ - of -oem- of van voorvoegsels, die allerlei bewegingen, standen, geluiden en gevoelens schilderen."

2) In dit verband zij ook herinnerd aan het bekende optreden van $y$ of $w$ na consonanten in oudere Javaanse woorden, waarin bij veel gevallen van ,inverse analogie" ook populaire uitspraak een factor kan zijn geweest. 
gwaya (spreekt.) = guwaya ,gelaatskleur”; kwalèn (gewest.) = kuwalèn ,(kook)pan” en andere gevallen waarin kw- wisselt met kuw-; kwèni ,esv. vrucht(boom)"; swiwi = suwiwi ,vleugel”; een gering aantal dus met $w$ in de eerste syllabe; byayah (gewest.) ,rommelig”; bya(k)byakan ,,jachtig”; byanamu, -né (grof) ,verdomd”;

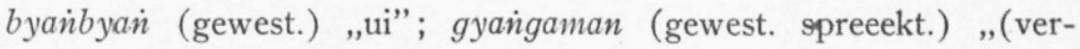
schrikt) in het wilde rondtasten”; kyaikaban (gewest.) „overal ruw tegenaan lopen”; kyan்kanan etc. (id.) ,zelfbewust-langzaam lopen”; patin kyuyus. (spreekt.) ,zielig drijfnat (geregend)”; pyanpyanan „licht rinkelen”; pyurpyuran (spreekt.) ,ontzet (van angst)”; wyagah (wiyagah) ,,(slechts) op de gis”. Met $w$ in de tweede syllabe: (veroud.) kěpwaìn ,moeten niezen”; képwan (= képyam, képon) „verbijsterd"; tokwèl, ,zich bemoeien met”. Met $y$ in de tweede syllabe zijn er vele: $a m p y a k^{2}$ (gewest.) ,,in een woeste drom lopen”; ampyai „,esv. geroosterde olienoten enz. met suiker”; dampyak ${ }^{2}$,,in gelederen (optrekken)”, dampyain ,samenhangend”; dumpyuk ,op, over elkaar, samenvallend etc.”; dompyok ,tros vol vruchten” = dompol; dompyò் ,charivari (aan horlogeketting)”; ěbyak „(in eens) openen”; ĕbyar (spreekt.) ,(in eens) geopend (gesloten hand)”; èbyèg ,,zich druk maken”; ěbyur (spreekt.) ,strooien (voor de kippen)”; ěmbyah ${ }^{2}$ (gewest. spreekt.) ,,algemeen (tezamen) gedaan”; е̌mbyak (gewest.) „,in de maat”; èpyè $k^{2}$,(onnodig veel) drukte maken (en weinig doen)"; $\dot{n}$ gabyĕg (gewest.) ,zonder ophouden (iets blijven doen)”;

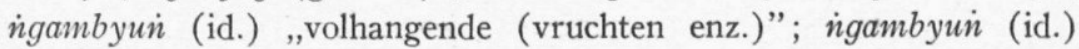
,alleen dansen”; gapyak ,vriendelijk, gezellig”: grapyak ,gezellig weten te praten (gastheer)”; gapyak (gewest.), bakyak ,houten sandaal”; gěbyag (id.) ,gelijkstaande met”; gěbyagi „,bonzen tegen (wand etc.)"; $\dot{n}$ gěbyah (spreekt.) ,algemeen”; gěbyah (gewest.) „omspitten”; nggĕbyak (id.) ,omgeklapt”; gěbyar ,glimp”; gěbyas „flesje”; gěbyug (gewest.) „met kracht komen aanstormen op”; gěbyur „,(met een plons) in het water springen”; gěbyog ,planken huiswand”; $\dot{n}$ ěmbyaki ,,(met pretmakers) mee gaan doen”; gémbyon (gewest.) ,volhangen”; gěmbyon் ,esv. broek”; gémbyar-gémbyor „,vermagerd en verslapt”; nglambyar „het smaakt (mij enz.) niet”; glémbyar-glémbyor „,flodderig erbij hangen”; gobyag ,schudden (fles etc.)"; gobyog ,luid en snel (geslagen, gamelan)”; ngobyos (gewest.) ,,in stromen (zweten)”; gumyah ,allerwege gehoord (gerucht)”; gumyak (gewest. spreekt.) „luidruchtig” = gumyěk; gumyur ,zeer ontsteld”; gupyuk=gupruk,,druk; ratelen (praten)" ; gĕgombyakan (spreekt.) „samen pret gaan maken”; ngrabyas (id.) ,,in een ogen- 
blik (weer) op”; ngradyag „neerplassen”; grambyan் „(vluchtig) tokkelen”; grěmbyĕñ ${ }^{2}$,geruis”; grĕmbyon ,,volgehangen (met versierselen)”; patin grěpyěk (spreekt.) „kraken (hout)”; grobyag ,daverend”; grobyog (gewest.) ,ingestort”; grombyan ,rammelen”; patin gropyak „tegen elkaar rammelen”; gropyok „met velen opjagen”; kampyak „mee een veeg uit de pan krijgen”; kĕbyok „(voorzichtig) uitgespoeld”; kĕmpyan், kĕmpyun „luidruchtig”; kěpyak (gewest.) ,,esv. kleppermuziekinstrument”; kĕpyak (id.) ,,voor het eerst”; $k \breve{e} p y a k$ (id.) ,,gewoon (lid van dorpsgemeente etc.)"; kĕpyar ,korrelig”; kӗpyěk (gewest.) „druk”, kěpyuk ,kletsen (in water)”; kе̌pyur „kleine spatjes”; kĕpyok, gěpyok etc. „met iets duns zwaaien tegen”; kĕrdyat „schrikken”; kěsĕmpyok „(een golf) over zich krijgen”; kipyah ${ }^{2}=$ $k_{i p r a h^{2}}$,hartstochtelijk-opgewonden (ronddansen) enz."; patin klëpyar (spreekt.) „overal, helemaal rul, los”; patin klěpyur (id.) „overal rondgesprenkeld”; klipyan (gewest.), klépyan (id.), kliptyan (id.) ,niet denken aan”; klombyar-klombyor (spreekt.) ,waterig dun”; kuměpyar ,zich verkwikt gevoelen”; kuměpyur ,in kruimels uiteenspringen"; kopyok ${ }^{2}$,,in water uitgespoeld"; kopyokan (gewest.) ,met groot lawaai”; kopyor „doorgelopen (bedorven ei)"; patin krambyain „overal ronddolen”, krampyan „met veel lawaai uitvaren tegen”; krapyak "gekletter"; krapyak ,esv. omheining”; patin krěmbyah „uitzwieren etc.”; krĕpyĕk = krěpěk „kraken”; krépyak „,rammelend”; krěpyak-krěpyěk (spreektaal) ,ineens met velen aanpakken”; krĕpyĕk ${ }^{2}$ „,neer (komen) regenen”; krimpyi ${ }^{2}$ (spreekt.) ,rinkelen”; krobyok $^{2}$ „ruisen”; krobyok „mee profiteren van”; krumpyan ${ }^{2}$ (spreekt.) „rinkelen”; krumpyunं (id.) „(kort en) hevig gonzen”; krupyuk ,opgestreken (geldstukken)”; mabyuñan „,wegzwermen”; mabyor (gewest.) „stralend”; mabluk ,grijs (onder het stof)”; nampyuk „tegen iets aan kletsen (water)”; nĕmpyok „,neerkletsen op”; nabyag(i) (spreekt.) „,wild”; nambyah-ambyah ,overal verspreid”; nambyan-ambyain (spreekt.) „onrustig, dwalen”; ñambyuri ,naspringen (drenkeling)"; nampyak ,wild aanvallen op"; $\dot{n} a p y u k(i)$ ,(water) in het gezicht werpen"; $\dot{n} \breve{e} b y u k(i)$,in nenigte neerkomen";

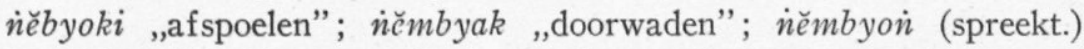
„opdirken (kind)”; ìĕmpyèg (gewest.) „,mee komen oogsten”; $\dot{n e ̆ p y e ̆ k ~}$ (spreekt.) ,dichtslaan”; irampyain (gewest.) ,rondgaan om te arbeiden (rijstsnijden)"; obyag (id.) ,in beroering (van velen)"; o(m)byog (id.) „danspartij”; $o(m)$ byon (spreekt.) ,omhangen (in slierten)"; obyor (gewest.) ,schittering”; ubyar ,helle schittering”; ubyan ,,in een troep meelopen (kwajongen)"; opyak ,misbaar maken”; (r)opyan² (spreekt.) 
,feestvieren (lekker eten)”; pyurpyuran (id.) „ontzet”; sampyĕn (id.) „druk (spel)”; sampyuh „tegelijk aanvallen”; tébyan (gewest.) „ongevoelig”, naast tébyas (id.), tégan, téga; tékyan (gewest. spreekt.) „,samen doen (handelszaak)”; tépyak (gewest.) ,dekplank (van brug)" en andere van dezelfde aard en betekeniskategorieën. Ook hier valt het grote aantal "gewestelijke” en spreektaalwoorden op. Er zijn onomatopeeën en klanksymbolische woorden bij, er zijn er die gebouwd zijn op een éénsyllabige onomatopoëtische interjectie, vooral beginnend met labiaal $y$ : byur ,plomp (in het water gevallen of gesprongen)", $p y u k$,ineens klotsen". Het aantal woorden voor geluiden, onrustige, onregelmatige bewegingen of met geluid gepaard gaande bewegingen is relatief groot; gemoedsbewegingen komen er onder voor; lichtgeven etc. is weinig vertegenwoordigd.

Ook het Oud-Javaans kent dergelijke woorden. Ik noem als voorbeeld van de door Brandstetter en Dempwolff niet vermelde woordvorm, de woorden met inwendige cons. $+w$, die met volgende $a$ $>o$ werd; kubwan "tuin" en die met ya>e: tampyal $>$ tampèl ,,slaan”. Voorts: krẹcik (ka-, of kakrěcik, niet-analyseerbaar) ,gekletter"; krětěb (ka-, alsvoren) "gedruis", krěbět ,gewapper"; grĕmus, gĕrěmus, garmus „krabben”; tlĕguk „doorslikken”; mal. tĕgok ,slok”. Met $r$ of $l$ in de tweede syllabe: unkrĕd ,inkrimpen”; kintran் ,,veel beweging maken”; gĕndruk „poezelig”; caikklin „,naar voren slingeren”; jëplak „,kappen”; timprut „,knijpen”; singron „afgrond”. Met $y$ : ampyal „esv. bamboe”; alisyus „wervelwind”; kalankyaì „esv. kiekendief”; kĕbyar ,ritselend”; kumyus „gudsen”; kurcyat ,geklemd”; kulyat ,zich rekken”; gan்gyan „,verbaasd”; gabyur „ontsteld”; garyain „droog”; gasyak „levendig”; caíkyak „overmoedig”; cantyal „vasthaken”; mulyar „schitteren”; lampyay „los hangen”; waikyul ,kleine schoffel”. Trisyllaba, die er uit zien als gevormd met het infix -ar-, -al-, maar dit zeker niet zijn: karakal en karikil , ,grint” (Lautbilder) ${ }^{1}$ ), karakah ,,esv. visnet”, kararas ,,verdord blad”; kalambi ,wambuis”; kĕrĕkĕt ,knarsen” (onom.); kĕrĕcěk „snorren” (id.), en andere met kĕrě beginnende onomatopeeën; kĕlěwin ,afgrond”; garañjaì „klotsen” (onom.); garawal ,haastigonthutst”; galintun „oneffen”; galuntan ,,ruisend, met geraas”: njav.

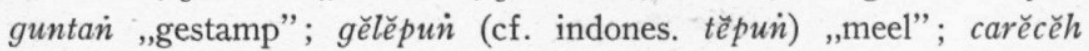
„kletteren”; calakutak „op de kaken slaan”; balunban „vijver”.

Er zijn echter reeds bij een oppervlakkig onderzoek in het Oud-

1) Zie Remarks, pp. 164, 167. 
Javaans verscheiden woorden te vinden, die vocaal $+l$ of $r$ meer hebben dan ernaast staande kortere vormen zonder dat in vele gevallen van een „, frequentatieve betekenis” sprake schijnt te zijn. Bv. taikěp ,aanpakken, slaags raken”: talaikkup ,de handpalmen tegen elkaar klappen of drukken” (kan „f req.” zijn); gape ,tastende zoeken”: gurapay ,idem”; tumpak ,betreden, opklimmen”: tulumpak ,bestijgen (scheepgaan)”; sasar ,afdwalen, verdoold raken”: salasar „idem”; tutur ,volgen”: talutur ,idem”; sěsök „vol”, kasěsěkan ,in het nauw gebracht": salěsok ,in het nauw gebracht, in een groot gedrang”; papal ,afgebroken”: parapal ,id."; babar ,uitspreiden, uiteengaan”: balabar ,zich uit de voeten maken, stromen”; sisir ,kant”: salisir „langs de kant (planten)"; pěpěs ,gekneusd, het onderspit delven”: pĕrĕpĕs (Wir. p. $58 \mathrm{~J}$.) „idem”; pěsat ,wegspringen”: plěsat „,spatten”; tandan: „,aanvallen”: talandaì ,idem”; gilap „schitteren”: gurilap ,idem”; patin burilap (zie boven); baikak „lichtgeraakt”:

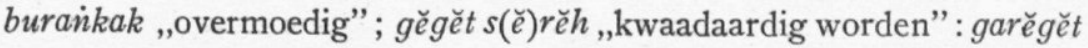
„vurig, zich verbijten”. Zonder twijfel wordt veelvuldigheid uitgedrukt door taritis „biggelen, druipen”; tiritis ,druipen” naast titis „druppel; het neerdruppelen”; njav. samberr ,neerschieten (v. vogel)”: a-sulambĕr-an (Çri Tañj. 5, 58) ,her- en derwaarts vliegen”. Misschien is julinah ,verheugd" met binah, bunah ,idem" te verbinden. Etc. Meervoud van onderwerp vinden we o.a. bij kuratil ,,in menigte hangen”; kurubut "door meer personen tegelijk aanvallen”; girimis „krioelen”; puratuk „spatten”; sarambah „overstelpen”.

In woorden als taluktak ,kletteren; molentje”; dalugdag ,wimpel”; sulisak ,uiteengejaagd" zal men uitbreiding met -al- -ul- mogen zien. Merkwaardig is kalula "familie” (Rām.), lasvorm van kula ,geslacht", leenwoord uit het Sanskrit?

In het Oud-Javaans vindt men een aantal trisyllaba, waar na de eerste consonant een andere vocaal dan $a$ of $\breve{e}+r$ of $l$ volgt : kiriñ cin ,gerinkel”; kuratil ,in menigte hangend”; kurambat ,omslingeren”; kurugěm „kirren” (?); kurucuk „kletteren”; kulawir ,in flarden hangen": njav. kazir ${ }^{2}$,er bij hangen, bijna doorgesneden"; kuluzerin "gudsen, suizen"; girahyas ,,in geestverrukking”; girimis ,krioelen”; girisin „sidderen”; gulimpan „omverrollen”; julinah „verheugd”; tulalay ,flikkeren"; puratuk ,spatten”; purinas en purinis ,,de tanden laten zien”; burěñà ,een brommend geluid maken”; muruñut „nors"; wuririn "te berge rijzen"; suliksak , het benard hebben". Hetzelfde in de tweede woordhelft: samburat „wegstuiven"; sambulih = „vergoeden, vergelden": vgl. silih ,afwisselend". Weer 
voornamelijk bewegingen, geluiden, affecten, onregelmatig voorkomen. De syllaben $u r$ etc., die hier op dezelfde plaats staan als elders $a r$ etc. worden niet voor infix gehouden. Waarom ar etc. dan wel? - Ook elders: tag. halikhik „gegichel”; tbat. halakkan „,met de benen uiteen staan”: mal. kankain ,idem”; tag. kalibkib „korst”; jav. karaingam "handvol".

De $r$ en de $l$ nemen in het systeem der talen, waarin ze voorkomen, vaak een afzonderlijke plaats in. $\mathrm{Zij}$ staan wat mondopening en klankvolheid (Schallfülle) betreft tussen consonanten en vocalen in; ze kunnen als vocalen optreden en syllaben vormen $(v a d r=v a d e r$, tafl $=$ tafel; skt. krtah, klptah); zij kunnen ook als consonant optreden bv. tussen twee vocalen (geboren) of na een consonant (drie). De volkomen vocalen en volkomen consonanten vormen systemen, waarvan de leden ,houvast” aan elkaar hebben : $i, u$ en $\ddot{u}$ hebben dezelfde sterke tongheffing (hoge of gesloten vocalen) en relatief gesloten mondopening, $e, o$, $\ddot{o}$ liggen lager, de $a$-klanken hebben de laagste tongstand en de wijdste mondopening. Maar er is tevens een andere indeling mogelijk: de tongmassa kan meer vóór, of meer achter in de mond geconcentreerd zijn; het eerste vindt plaats bij de $e$ en $i$, het tweede bij de $o$ en $u$. Zo staan de vocalen, en eveneens de consonanten, op enkele na, in onderling verschillende relatie. De $p$ heeft bv. met de $b$ zijn articulatieplaats gemeen en niet geaspireerdzijn (beide labiaal), met de ph zijn stemloosheid (in tegenstelling tot $b$ en $b h)$, met de $t$ zijn stemloosheid en niet geaspireerd-zijn etc. De liquidae vormen echter een groepje, dat buiten het systeem der vocalen en buiten dat der consonanten staat. Wij voelen de $r$ - en $l$-klanken als een afzonderlijke klasse, die in oppositie staat tot de andere klassen ${ }^{1}$ ).

De regelmatige, in vele talen normale syllabe is zoo gebouwd, dat de mondopening van de aanvang tot de vocaal groter, vandaar tot het einde kleiner wordt ${ }^{2}$ ). Welnu, de kleinste mondopening (nul, geen opening) hebben $p, t, k, b, d, g$; dan volgen $f, v, s, z$, de Nederl. $g$ etc., dan de nasalen, daarna $l$ en $r$, dan $y$, $w$, dan $i, u$, $u$, vervolgens $e, o, \ddot{o}, \operatorname{dan} a$. Een woord als pfrailst vormt dus een syllabe, evenzo klest, brusk; maar niet frpailst; hier wordt de $r$ vocalisch en het geheel wordt tweesyllabisch; immers van $r$ tot $p$ wordt de mond

1) Vergelijk over een en ander ook N. S. Trubetzkoy, Grundzüge der Phonologie, Travaux du cercle linguistique de Prague, VII (1939), p. 132 vlg.; N. van Wijk, Phonologie (1939), bl. 45 vlg.

2) Uitvoeriger bv. bij M. Grammont, Traité de phonétique (1933), p. 99. 
weer gesloten en na de $p$ gaat hij weer open. Hieruit volgt dat $l$ en $r$, evenals de nasalen en $y$ en $w$, zich zonder dat de eenheid van de syllabe wordt aangetast tussen aanvangsconsonanten van de eerste en tweede kategorie en een vocaal (of ook andersom: tussen vocaal en volgende dergelijke consonanten) kunnen voegen. En op deze wijze ingevoegd wijzigen zij het geheel van het woordbeeld niet zo dat het onherkenbaar wordt. Veelal wijzigen ze de reële betekenis van het woord niet, wel lenen ze zich zeer goed om een nuancering hetzij in reële betekenis, hetzij in gevoelswaarde uit te drukken. Dat, wanneer eenmaal in een syllabe een extra $r$ etc. optreedt, deze licht aanleiding kan geven tot een svarabhakti-vocaal, doet aan de geldigheid van het bovenstaande niet af; ook de nieuwe combinatie wijzigt de betekenis in de regel niet wezenlijk. Deze svarabhakti-vocaal heeft (althans bij de Germaanse lasvormen ${ }^{1}$ )) neiging te harmoniëren met de vocaal van de syllabe waarin hij is bijgekomen; in de Germaanse voorbeelden is echter, hiertegen in, tevens een sterke voorliefde voor de $a$. Dat die vocaal in Indonesische woorden in de antepaenultima $\breve{e}$ is, is geheel in overeenstemming met de neiging van de vocaal in die talen op die plaats tot pěpět te worden. Dat er incidenteel invloed van volksetymologische aanknoping op de kleur van de vocaal kan uitgaan ligt voor de hand.

We zien dan ook in de praktijk herhaaldelijk dat speciaal de $r$ en de $l$, ook wel $y, w, m, n$ plaatsen innemen, die de volkomen consonanten niet kunnen bezetten. In het Sanskrit bv. staan aan het eind van een woord nooit twee consonanten; de combinatie $r+$ consonant is echter mogelijk. In het Nederlands staan (van enkele zeldzame woorden afgezien) aan het begin van een woord slechts de verbindingen van drie consonanten: $s p r, s t r, s c h r, s p l$, en van de 28 mogelijke tweeconsonantische Anlaut-groepen zijn $9 r$-verbindingen $(k r$ etc.), $7 l$-verbindingen ( $s l$ enz.); voorts $s m, k n, s n$; $t w, k w, d w, z w ; s j, t j$, $s p$, st, $\left.s \mathrm{ch}^{2}\right)$. In het Engels staan aan het begin van een woord geen drie consonanten, behalve wanneer de laatste $r, l$ (of $w$ ) is; vele combinaties van twee consonanten komen in Anlaut niet voor, behalve wanneer de 2e $r, l$ (of $w$ ) is : pray, tray, play; split; nooit $p k, p t, p m$ etc. In het Frans vindt men aan het woordeinde gewoonlijk een vocaal of slechts één consonant; vrij vaak treedt echter occlusief $+r$ of $l$ op: ombre, table, enz.

1) Schröder, o.c., p. 240.

2) J. van Ginneken, De Nederlandsche consonantgroepen, Onze Taaltuin, VII, p. 33 vlgg. 
Gaan dus $l$ en $r$ (en in mindere mate $w, y, m, n$ ), meer combinaties met consonanten aan dan de volkomen consonanten, uit tal van voorbeelden blijkt hun belangrijke rol bij de uitbreiding tot grotere eenheden, hun hoge mate van ,inschuifbaarheid”. In allerlei talen vindt men naast elkaar woordvormen zonder en woordvormen met een $l$ of $r$ (of ook y) méér, doubletten met als enig verschil het al of niet aanwezig zijn van een liquida. Bv. gr. $\varkappa \alpha \gamma \chi a ́ \zeta \omega: ~ \varkappa \alpha \gamma \chi \lambda a ́ \zeta \omega$ „schreeuwen”; ned. dreinen: zaans deinen, denen „koppig doorzetten”; brullen: mned. bullen „,razen, tieren”, bulderen; trippelen : tippelen; naast ned. babbelen: deens blabre, odeens blable, eng. blab „,babbelen”, vgl. ook ned. brabbelen; blaffen: mned. etc. baffen; noors gissen: grissen, glissen ,de tanden laten zien, grijnzen”; gyse „huiveren, rillen”: ouder deens gryse ,huiveren”, fr. argot beffleu "larron, filou": bleffleu ${ }^{1}$ ). Het betreft hier primitieve woorden of woorden, die onder invloed van primitieve tendenzen staan. Ook het optreden van een niet-etymologische $y$ na consonant kan men in verschillende talen waarnemen. In het Noors bv. is het een welbekend verschijnsel: no. bjeffe, ouder deens baeffe, duits bäffen „blaffen”; pjadre ,kletsen”: ouder deens padre ,idem” e.a., maar ook in woorden als bjerge ,,bergen"; in Friese dialekten is $y$ na medeklinker in Anen Inlaut welbekend. Het verdient intussen onderzoek welke fonetische waarde de $y$ in de hier behandelde Javaanse woorden heeft ${ }^{2}$ ).

Alvorens met deze opmerking te vervolgen breng ik in de herinnering terug, dat $r$ en $l$ vaak in bepaalde klankgroepen een zekere symbolische waarde hebben, een bijzondere gevoelstint verlenen aan de woorden, waarin ze voorkomen: ned. flikkeren, flitsen, flets, flauw (een zekere bewegelijkheid en onbestendigheid wordt door deze $\mathrm{fl}$ gesuggereerd); gluipen, glibberen, glijden, glop (= slop), glad; ruisen, druisen, bruisen; eng. hurl, curl, furl. Vaak zijn er blendings (mengwoorden bij), vaak hebben dergelijke groepen hun impressieve waarde pas gekregen door een toevallige omstandigheid: enkele woorden met een zekere gevoelswaarde hadden of kregen dergelijke klankcombinaties. Ook in suffixen: in du. theoreteln en dergelijke: heeft -eln een bepaalde, deprimerende gevoelswaarde; fr. -erie suggereert on-

1) L. Sainéan, Les sources de l'argot ancien II (1912), s.v.

$\left.{ }^{2}\right)$ Vgl. bv. H. Zwaardemaker en L. P. H. Eykman, Leerboek der phonetiek (1928), p. 190. N. Adriani, Sangireesche Spraakkunst, p. 152 merkt op, dat al, het (Streck)infix, graag $+i$ uitgesproken wordt, d.i. gemouilleerd: „een versterking van het infix, een bredere en meer golvende wijze om de $l$ uit te spreken." 
gunstige eigenschappen: gaucherie, bizarrerie, poltronnerie; -eron en -elet zijn verkleinend: moucheron, agnelet; -aille is ,ongunstig verzamelend": ferraille, journaille. Het is een objectief vaststaand en boven reeds gememoreerd feit, dat bv. de $r$ in vele talen in onomatopoëtische en andere primitieve woorden (niet in kinderwoorden!) voorkomt en dan dienst doet een indruk te wekken die adaequaat is aan die van krakende, knetterende, grommende, ratelende etc. geluiden, van brekende dingen, van trillende en sidderende bewegingen etc. $\left.{ }^{1}\right)$ : gr. $\varkappa \varrho \alpha ́ \zeta \omega$,krassen van raven; schreeuwen o.a. van dieren”, $x \varrho \omega \zeta \omega$,idem (van kraaien, mensen, enz.)”, $x \lambda \omega \zeta \zeta \omega$,klokken, honen”;

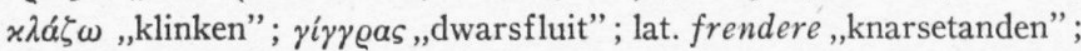
ned. krassen; grommelen, frommelen, grabbelen, fr. fric-frac, gron$d e n$, enz. enz.; dat $r$ en $l$ in woorden die zwakkere geluiden, geluiden van een zekere duur aanduiden en andere geluidswoorden veel voorkomen; bijzonder vaak bij geluiden die herhaald worden, die samengesteld zijn, die uit reeksen korte geluiden bestaan; vgl. eng. clank, clap, click, crack, plop; ned. ploef, roef etc.

Ook in de Indonesische talen bevatten zeer veel primitieve woorden $r$ of $l$ : bv. werkwoordelijke tussenwerpsels, soend. rěp ,stil worden”, rĕm ,aan het werk gaan”, rap „komen”. Er is echter behalve deze uit drie klanken bestaande vorm van het ,werkw. tussenwerpsel” nog een andere $\left.{ }^{2}\right)$ : cons. $+r+$ voc. + cons. : soend. bral ,vertrekken", brak ,(met een maaltijd) aan de gang gaan”; pruk „(uit)werpen”; prun „op de loop gaan”; prok ,ontmoeten”; srog ,naderen en zich neerzetten bij”. Er zijn ook bij de primitieve monosyllaba in Indonesische talen vele paren: veel in het Atjehs: $c i b^{2}: c r i b^{2}$ "getjilp"; soend. w. t. bèh : brèh ,zichtbaar worden”; w. t. pĕt „breken, knappen”: prět; w. t. bol: brol „te voorschijn komen”; mal. dam: dram, derram "geluid van een trom”; $d u p-d a p: d(\check{e}) r u p-d(\breve{e}) r a p$,het gestamp van vele mensen". Men mag aannemen dat de $r$ (en evenzo in andere gevallen event. andere klanken) het door het woord uitgedrukte affectieve element souligneert, het een zekere nadrukkelijkheid verleent. Maar ook in langere primitieve woorden : mal. kiok ,(onom.) cluck of a frightened fowl”; kerriok „kraaien (haan), kakelen, klokken”, kokok-kĕriok ,kakelen en kraaien”. Er zijn ook twee- en drielettergrepige „werkwoordelijke tussenwerpsels", die emfatischer

1) M. Grammont, Traité de phonétique, p. 389 ; Remarks, p. 87 vlg.

2) R. A. Kern, wiens artikel over de Soendase umpak basa (Bijdr. 102, p. 81 vlg.) mij onder de ogen komt nadat het bovenstaande is geschreven, spreekt hier van de sterke vorm. 
zijn $^{1}$ ): jĕdod (w. t.) „slaan”; de drielettergrepige zijn uitgebreid met vocaal $+r$ of $\left.l^{2}\right)$ : wěk : běrěwěk voor „openscheuren”. Soms staan één- en meersyllabige vorm naast elkaar, soms niet. In het Javaans is op $d \check{e} t(-d \check{e} t)$,kleine rukjes geven aan” gebouwd ndrĕdĕt ,trillen (als dráad, waaraan men trekt)".

Is in vele gevallen in primitieve woorden deze klank vanaf den beginne aanwezig geweest, in andere gevallen kan men aantonen, dat, wanneer er twee overigens gelijke woorden naast elkaar staan, waarvan een de $r$ of $l$ wel, de andere niet heeft, het woord zonder de liquida de oudere gedaante vertegenwoordigt en dat het woord met de liquida onder invloed van klankexpressieve of -symbolische tendenzen, van analogie, blending etc. is ontstaan. Zo is fr. fronde „katapult” $<$ fonde, lat. funda ,slinger, werpnet”; fr. gringalet (1611) een ,altération" van guingalet (12e eeuw) „esv. paard"; ned. friemelen is jonger dan femelen en fiemelen; fr. tingle (1328) ,richel, lijst" < ned. tingel, tengel, 16e eeuw tringle; ned. vlonder misschien een jongere vorm naast vonder; eng. grist ,,solecism for gist" ${ }^{3}$ ); mengl. splot naast spot; eng. frizzle ,champagne” ,a perversion of fizz?” $\left.{ }^{3}\right)$; sockdolager, $s l-, \operatorname{slog}_{-}$,a very heavy blow” $\left.{ }^{3}\right)$; du. $\operatorname{Schrank}(e): \operatorname{Schank}(e)$ „Hürde" ${ }^{4}$ ); noors skrukka : skukka ,vore; rimpel”; oijsl. skrokkr: skokkr ,du. ranzen" ${ }^{5}$ ); het is bij deze woorden niet steeds zeker hoe de beide vormen zich verhouden. Ook in het Oer-Germaans en OerIndogermaans komt men tot verscheiden doubletten: wortels die naast een vorm cons. $+r$ (zelden $l$ ) + vocaal de vorm cons. + vocaal hebben. Voor het Germaans komt Noreen ${ }^{6}$ ) tot deze formulering: er zijn woorden met anlautende cons. $+r+$ wortelvoc., waarnaast een vorm zonder $r$; en er zijn woorden die tussen anl. cons. en wortelvoc. een $r$,eingeschoben" hebben; ,von den vielen Beispielen sind die meisten etwas unsicher; viele brauchen nur Reimwörter zu sein". Men vergelijke bv. ahd. sprehhan, ned. spreken met ags. specan naast sprecan en dergelijke, waarvan Noreen een lijst geeft. Ook op Indonesisch gebied valt in een aantal gevallen aan te tonen, dat een woord met $r$ een jongere gedaante vertegenwoordigt: njav. srěnéné ,zon” <ojav. saihyanzwé ; trapsila ,welgemanierd" < tapsila ; trusța „tevre-

1) Vgl. Kern, o.c., p. 84 .

2) Bijzonderheden, Kern, p. 85.

3) E. Partridge, A dictionary of slang and unconventional English (1937), s.v.

4) H. Schröder, Paul u. Braune's Beitrage z. Geschichte d. deutschen Sprache und Literatur 29, p. 503.

5) A. Noreen, Atlisl. Gramm. ${ }^{3}$, § 312, 4 Anm.

6) A. Noreen, Urgerm. Lautlehre, p. $220 \mathrm{vlg}$.

D1. 102. 
den, behagen scheppen in" naast tusța (beide literatuurwoorden) < skt. tusta-.

Men pleegt de uitbreiding van een woord met een enkele consonant op de in dit opstel besproken wijze geen Streckform te noemen. Ontstaat er echter na het optreden van die consonant een svarabhaktivocaal, dan wel. Principiëel verschil is er niet. Ook het optreden van "streckende consonanten" is een algemeen en primitief verschijnsel. De kindertaal kent het: „Le terme enfantin est souvent amplifié par l'addition des liquides, dentales etc.”, constateert Sainéan, die als leerzaam voorbeeld de woorden voor de kreten en de liefkozingsnamen van de kat behandelt ${ }^{1}$ ). Bij ,de primitieve woorden” ,il s'agit en premier lieu du redoublement, ensuite de l'addition de liquides, l'un et l'autre phénomène ayant pour but de donner aux mots enfantins ou onomatopéiques, primitivement monosyllabiques plus de consistance, plus d'ampleur" ${ }^{2}$ ).

Vatten we samen. Het lijkt mij in de eerste plaats aan geen twijfel onderhevig, dat er in de Indonesische talen „las-vormen” voorkomen, waarvan een deel een uitbreidend element heeft waarvan de gedaante niet samenvalt met die van een der bekende affixen. Het is aannemelijk, dat er onder de driesyllabige woorden van overeenkomstige gedaante, waarnaast geen tweesyllabige staan, ook uitgebreide woorden, Streckformen zijn. Een uitvoeriger taalvergelijkend onderzoek dan hier nodig was zal er nog menige aan het licht kunnen brengen. Hiermee is echter volstrekt niet gezegd, dat alle trisyllaba zo ontstaan zullen zijn. In de tweede plaats zijn er Streckformen, die een uitbreidend element bevatten, dat wel in gedaante overeenkomt met een der bestaande affixen. In de eerste plaats die met $u m$, $\breve{m}$ zijn uitgebreid. Een principieel bezwaar aan te nemen, dat ook deze syllaben „streckend" kunnen optreden zie ik niet. Men kan, zoals boven reeds gedaan is, er op wijzen, dat $u m$ ook in zuivere niet verder ontleedbare onomatopeeën voorkomt. Daaraan kan men toevoegen, dat het zich in dergelijke woorden zelfs met ěr etc. kan verbinden : ojav. kuměrěkĕt „knarsen”, gumirisin „,sidderen”, gumurungun ,luid klinkend”; njav. gumrènjèn „kletteren van water door een pijp”, mal. gĕmĕlĕgut ",beven”. In het Bataks beschouwde Van der Tuuk ${ }^{3}$ ) deze groep als een afzonderlijke: ,zamengesteld afgeleide werkwoorden”. Hieronder rekent hij werkwoorden met um èn $a r$ : sumaringók ,luid snikken

1) L. Sainéan, Les sources indigènes de l'étymologie française 2, p. 410.

2) Ibidem, p. 407.

3) H. N. van der Tuuk, Tobasche Spraakkunst, § 88. 
van velen” e.a. „De meeste dezer werkwoorden zijn klanknabootsend, en schilderen door de $r$ een knetterend, klapperend, ratelend geluid, dat verder is toegepast geworden (sic) aan 't geen zich onregelmatig aan 't oog voordoet". Er zijn ook $u m+\breve{e l}$ of $a l$-woorden, die voor het grootste deel evenals de vorige groep met $g$ of $h<k$ aanvangen ${ }^{1}$ ); „(zij) hebben zeer zelden een gangbaar woord tot stamwoord”. Deze woorden zijn met de Maleise gěměrě-, gěmělě-woorden te vergelijken; van verstarde infixen is m.i. geen sprake.

Hiermee wil ik niet beweren, dat het infix -um- in woorden als oudjav. kumĕmit genetisch niet met het ,primitieve" um kan samenhangen. Dit is een punt, dat nader onderzocht moet worden. Wel doet zich ook hier weer de vraag voor: waar ligt de grens tussen het primitieve en relatief stabiele en arbitraire taalsysteem ${ }^{2}$ ). Immers ook hier vertoont de bouw van Indonesische talen een punt van overeenkomst met wat in verschillende andere talen typisch is voor ,primitieve" woordbouw ${ }^{3}$ ). Speciaal interessant zijn de woorduitbreidingen met de liquidae.

Dat er al-woorden zijn, waarin al geen infix is, betoogde ook Adriani ${ }^{4}$ ): van het Sangirese praefix bali*-, bali*-, pali*- is de betekenis onzeker, het bevat niet het infix -al-, tenminste niet dat wat frequentatieven vormt; er zijn niet veel voorbeelden van. Bij palinta$k u b \breve{e}^{s}\left(m \breve{e}^{s}-\right)$,omslaan (van een prauw)" bestaat een nevenvorm: mĕlintakubĕs ,zich omkeren (van een op de rug liggend kind)”, waaruit, zo betoogt Adriani, blijkt, dat het woord geen frequentatief infix bevat. Bij enige woorden met para-, pala- kan er twijfel aan betaan, of zij het frequentatieve -al- bevatten. Bij de meeste pleit volgens Adriani de betekenis ervóór: bv. paralinso „huppelen”. In een woord als palaguntin echter ,houten in de vorm van een schaar gekruist om een stellage op te bouwen” (bij guntin „schaar”) duidt pala- gelijkenis aan, verg. bis. salagontin ,getimmerte in de vorm van een geopende schaar”, jav. sriguntï̌ĕn ,kriskras”. Uit mijn hierboven gemaakte opmerkingen meen ik te mogen concluderen, dat er ook Streckformen met $a r, \breve{e r}, a l$, $\breve{l} l$ zijn, evengoed als met $u r$, al etc., en dat er naast deze ook liquida zonder vocaal als woorduitbreiders kunnen optreden.

Een argument voor het aannemen van gelijkwaardigheid van $a r$-,

1) Ibidem, $\S 91$.

2) Zie Bijdragen, 99, p. 447 vlg.

3) Ibidem, p. 433.

4) N. Adriani, Sangireesche Spraakkunst, p. $139 \mathrm{vlg}$. 
al- Streckformen met uit de norm vallende trisyllaba zie ik in de driesyllabige umpak basa van afwijkend type (burahol etc.) ${ }^{1}$ ), die dezelfde functie hebben als de regelmatig gevormde driesyllabige umpak basa.

Een ander argument kan men ontlenen aan de combinaties met patin etc. De Javaanse grammatika's leren, dat de ,samengestelde frequentatieven gevormd worden" door patin + een vorm met infix $-a r-,-\breve{e r}-,-r-,-a l-$-, $-\breve{e} l-,-l$ - in de eerste syllabe van het grondwoord. Maar het feit doet zich voor, dat patin ook optreedt voor woorden, die die klanken in hun laatste deel hebben, ja voor woorden, die geen $l$ of $r$, maar een andere halfvocaal bevatten; ja zelfs voor woorden, die ook die niet bevatten, maar een (al of niet volledige) reduplicatie; ook voor trisyllaba: pin sěmbèrèt ,zich overal met straaltjes versprei-

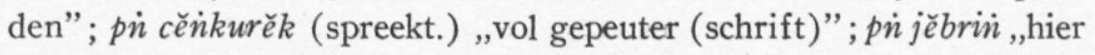
en daar een haartje"; - pri patinkrain ,heel-hoog gaan zitten”; $p \dot{n}$ cěnainlun „allen, geheel met het hoofd vooruit”; - patin kyuyus

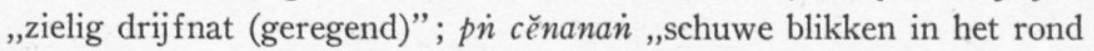

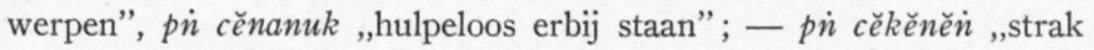
staan (spieren)”, pin cěkěnik (spreekt.) ,geheel peuterig”, naast

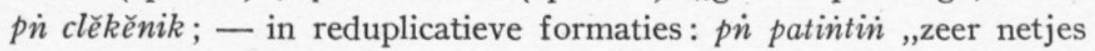

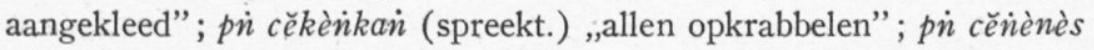

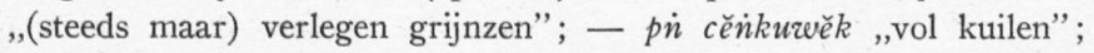
pri cĕninak „met gespannen aandacht rondkijken”; - soms komen liquidae in beide syllaben voor : $p \dot{n}$ clěrikrà ,overal prikken voelen”; pin clèprèt ,,geheel bemorst, bespat”.

In het Oud-Javaans, althans in de thans uitgegeven teksten, komen patin-verbindingen weinig voor, doch het interessante is, dat patin niet aan $(a) r(a) l$ - woorden gebonden is: patin burěnik, ,aan alle kanten kermen”; patin burilap ,overal flikkeren”, naast patin parapal ,overal afbreken”; pati sěsěmbahi (Kor. 66, 33); pati suliksak ,overal heen afdwalen". Voor het Soendaas merkte Oosting op, dat patin gurilap „meervoudsvorm” van ,blinken, schitteren” ,zou moeten zijn patingarilap" ${ }^{2}$ ). Dwz. gurilap vormt een uitzondering.

De bekende regel der Javaanse spraakkunsten, dat bij de patinformatie in het grondwoord geen ,ingevoegde" liquida of $a+$ liquida optreedt, wanneer het grondwoord reeds een medeklinker gevolgd door $r$ of $l$ tot beginklank heeft, komt hierop neer: in deze formatie

1) Zie boven, p. 389 .

2) H. J. Oosting, Soendasche grammatica, § 126. 
zijn de steeds met liquida voorziene woorden gelijkwaardig aan de ad hoc met liquida uitgebreide vormen. Ja zelfs op andere wijze driesyllabige woorden delen in deze gelijkwaardigheid: patiñ bĕcècèr "overal verstrooid"; patin pancolot = patin crolot „overal springen" ${ }^{1}$ ).

Aan de ene kant dus gelijkwaardigheid van $(a) r(a) l$ met primitieve woorduitbreidende elementen en (ruimer) gelijkwaardigheid van met ar al uitgebreide woorden met trisyllaba van andere gedaante, aan de andere kant kan men toch niet ontkennen, dat ar in de Javaanse "frequentatief" een systematisch optredend infix is, evenals het "meervoudvormende" $a r$ in het Soendaas, dat bij verschillende woordsoorten optreedt daar waar sprake is van een veelheid, veelvuldigheid, van een ,in meer dan een opzicht” en ook wel daar, ,,waar het onnodig is", dwz. het meervoudig begrip toch reeds blijkt.

Staan we daarom bij dit element nog stil. Interessante punten van overeenkomst met de Javaanse woorden die $r$ of $l$ etc. bevatten vertonen woorden in het Bataks. Zoals boven reeds is opgemerkt, is er een groep van „werkwoorden”, die een geluid of beweging van velen aanduiden: intransitiva als sumaringok ,luide snikken van velen"; zij worden gebezigd van meer dan een persoon of voorwerp, waaraan een zelfde toestand wordt waargenomen. Gelijkwaardig wat betreft gebruik en betekeniskategorie zijn woorden als rumangiok ,snikkend schreien”; er is een groepje met ruma + nasaal aanvangende dergelijke woorden ${ }^{2}$ ); inplaats van rumangadap heeft het Dairi gumerradap „neervallen”. Daarnaast een groep klanknabootsende woorden, die meestal met $h<k$ of met $g$ beginnen, terwijl hun grondwoord slechts zelden een gangbaar woord is: dumarede „biggelen (van tranen)"; een derde soort met $a r$ - en deze tevens met $a l$ - zijn die, welke met mar-anvangen ${ }^{3}$ ) : „Dikwijls zijn deze werkwoorden afgeleid van een woord, dat meer dan twee lettergr. heeft, of wel meerlettergrepig geworden is door middel van 't voorh. $h a$, of de inhechtsels al en ar; bv. mardjarumbun ,dicht”; margalusak „trappelen in..." etc. „Zoo hun stamwoord niet op gemelde wijze drielettergrepig is gemaakt, dan vertoont het in zijn laatste lettergrepen twee verschillende klinkers, die in de tongvallen, die een halfklinker hebben, door een $j$ (d.i. $y$ ) of $w$ gescheiden zijn: marpateyak „,kakelen”, marjaguwa etc. Minder vaak staat tusschen syllaben een

1) Vgl. H. N. Kiliaan, Javaansche Spraakkunst, § 82.

2) Van der Tuuk, o.c., § 87.

3) Van der Tuuk, o.c., $\S 52,5 ; 89$. 
liquida: margambura ,fijn als waterstof”. „Deze werkwoorden bootsen een geluid na, dat een zekeren duur heeft, een beweging, die zich verschillend aan het oog voordoet, en verder een hoedanigheid, die zich door onregelmatigheid als het ware als een beweging voordoet: markarujut (mand.) „kroezelig zijn van het haar”, marjambuzean ,welig groeien van onkruid" ". Wederom dus trisyllaba met $r l y w$, ook in de tweede syllabe weer dezelfde semantische kategorieën ${ }^{1}$ ). "Sommige dezer werkwoorden hebben de $a$ van het inhechtsel in $u$ veranderd" ${ }^{2}$ ): dit is een onjuiste formulering, beter is: hebben niet ar maar ur: marpuronjok. Dan zijn er nog $r$-woorden die met manaanvangen, bv. mangarogo ,verkrachten”. „Van de meesten is het stamwoord niet gangbaar”: vgl. Maleise uitdrukkingen als měngĕlotak „de doppen van een kokosnoot verwijderen”; mĕrigělugut „,klapperen (van de tanden)”, měngělupar „(van een vogel die geslacht wordt) krampachtig spartelen”, maar měngělosok ,steeds maar door wrijven” bij gosok ,wrijven”. Ook hier kan een halfvocaal in de tweede woordhelft optreden. Ook hier is ,in de beteekenis het begrip opgesloten van een onregelmatigheid, die ahw. een beweging is". Er zijn ook $l$ woorden, die met man- aanvangen ${ }^{3}$ ) : mandalese ,zich kaal vertonen”. „Zondert men het voorhechtsel en inhechtsel van dezen vorm af, dan verkrijgt men woorden, die in beide lettergrepen denzelfden klinker vertoonen, en waarin de eerste met een $d$ begint". Er zijn tenslotte nog enkele $a l$-woorden, die met pa aanvangen: patalindan ,zich dooreenstrengelen". Derhalve: enkele sterk aan zekere semantische kategorieën gebonden, ten dele ook in overige woordgedaante bepaalde groepen; in een deel daarvan is pluraliteit van personen of objecten te constateren.

In het Karo-Bataks worden geen nieuwe woorden met inwendige $a l$ en $\breve{r}$ meer gemaakt, er zijn er slechts weinig ${ }^{4}$ ). Van de meeste, die Neumann opgeeft, is het grondwoord „onbekend”; m.i. wil dit zeggen, dat ze niet analyseerbaar zijn. In het algemeen duiden de uitdrukkingen van deze gedaante aan een geluid of beweging die zich herhaalt: gĕruduk běltěkku ,mijn buik rommelt”; kĕliper ,stuiptrekken”; ook substantieven hebben deze gedaante : gĕrantuñ ,muziek-

1) Vg1. ook de opmerking van Van der Tuuk, p. 112 Aanm., die er op wijst, dat vele benamingen van geluiden en van dieren naar hun geluid dezelfde gedaante hebben.

2) Van der Tuuk, o.c., § 89.

3) Van der Tuuk, o.c., $\$ 93$.

4) J. H. Neumann, Schets der Karo-Bataksche Spraakkunst, § 112. 
instrument”. „Bij gěladap „omvallen, flauwvallen” is echter alleen een toestand te constateeren; mogelijk hebben wij hier te denken aan den persoon zelf, ,dien het draait voor zijn oogen” ", veronderstelt Neumann; m.i. is hier eerder te denken aan de affectief-soulignerende functie van de liquida ${ }^{1}$ ): het grondwoord is misschien gědap „wegzinken (in water, modder enz.)".

In het Maleis vinden we een zeer gevarieerd beeld, dat in de grammatika's niet blijkt, doch in een beschrijving van de taal zoals we die hebben van Bare'e en Mori zonder twijfel veel duidelijker zou uitkomen. In hoofdzaak staat het met de $\breve{e} l$ en $\breve{e r}$-woorden als volgt: Naast verscheiden namen van planten bv: gělukap „rhizophora mucronata"; kĕlěmuntin̈, kĕrĕmuntin, kĕmuntin "rose-myrtle”; kĕlĕpayan், kěpayan் „pangium edule”; en van dieren: kĕlawa (op Borneo) $=k a w a^{2}$ (Batavia) „spin”; kĕlěrikiak „bulldog-ant” = kiak ${ }^{2}$ (verscheiden nevenvormen) ${ }^{2}$ ); bělalan „sprinkhaan”; těnok, těrĕnok „tapir”; die ten dele niet te analyseren zijn, ten dele de indruk maken uitbreidingen te zijn van disyllaba, bestaan verscheiden niet-analyseerbare trisyllaba als bĕlakain „rug etc.”. De semantische kategorieën van de $\breve{l} l$ en $\breve{e} r$-woorden zijn: lichaamsdelen: gĕlabir ,halskwabbe”;

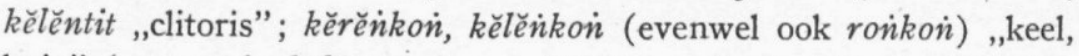
huig” (maar pah. kĕlěpar, singap. kĕlěpir = buah pělir ,testikels”); gebruiksvoorwerpen, wapens, bouwwerken, onderdelen van bouwsels en derg. : dĕlěmak ,geborduurd kleed”; gělĕgar ,dwarshout”; gĕragai ,haak om krokodillen te vangen”; jĕrěmbah „,dek (van een schip)”; jĕrumbun „,bijenkorf-vormige hut”; kĕlalan ,,kalabas-vormige waterkan”; kĕlu(m)bon ,sluier” (ook ,door een sluier bedekken”); kĕroncot "funnel-shaped rice-holder of leaf”; palancar „hoofdbalk van een huis”; sĕlukat „esv. muziekinstrument”; sěrampan் „drietand; esv. speer”, etc.; lekkernijen, etenswaar: jĕradek „esv. cake”; kĕlĕmben „esv. ,sponge-cake”; sĕlurai ,esv. vermicelli”; bijzondere houdingen, manieren van zich voordoen etc.": jěliniar ,even zijwaarts zien” (maar vgl. jĕlin „,een betekenisvolle blik ter zijde werpen”; gělěpak „slap hangen (van een zwaar voorwerp)"; gěrěnyin̈ ,grijnzen” (aаp); gĕrepek ,zich niet reinigen na het voldoen aan een natuurlijke behoefte”; gerrigis ,gekerfd, getand”; bĕr-kělanut ,dde kin opheffen en naar boven kijken”; kělěpai ,slap neerhangend”; vaak tevens een verward, onregelmatig zijn etc.: gělěmbur ,diepgegroefd, met diepe

1) Boven, p. 417

2) Zie Wilkinson, Mal. Engl. Dict. I, 595. 
rimpels (huid van zeer oude vrouw)”; derrisip (buta d.) „esv. blindheid”; gěligis „ongelijk gesneden of geknipt (papier, haar)”; gĕlodar

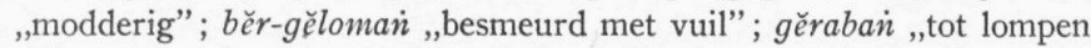
gescheurd etc.”; jĕrabai ,uitgerafeld”; měnjĕrěmbeh ,afgetrapt-slordig”; kĕlalut etc. "gekronkeld”. Woorden voor begrippen als: ked. dĕrĕlus ,stukrotten”; měnjělěmpah ,in grote hoeveelheden rottende liggen”; gělěkak „,afschilferen”; gĕrěnyak „mengen en bederven”; gěranyok ,bederven”; gěrapak „,snoeven”. Woorden voor andere verbale en nominale begrippen : jĕrumat ,stoppen (sokken etc.)”; jĕrukup „overkoepelen”; sělumbar „hout-splinter”; sěrĕmban „esv. kinderspel”; gĕronigan் „holte, hol”; gẹ̆ladir (Batavia) „slijm etc.”; kĕladak „droesem”; gĕlombaì „grote golf”. Een scheldwoord: děrěmem „dirty-face”. Een groot aantal onomatopeeën, Lautbilder etc., geluidsen bewegingswoorden, bv. vele met $m \breve{e}+$ nas. + gĕl $(\breve{e}), \operatorname{ger} r(\breve{e})$ aanvangende: měngĕlanisar „voorwaarts glijden”; měngělinyar ,jeuken”; měngěleser „rusteloos bewegen”; mĕngĕrodak „kletteren, rammelen”; voorts gělětak ,het geluid „tak” maken”; gěrantan் ,een weerklinkend geluid maken, schrik aanjagen”; gĕrosak ,ritselen”; kĕrosok „kraken (bv. van droge blaren onder zware stap)"; kělěntan ,herhaald bonzen”; těr-pĕranjat ,plotseling opgeschrikt”; salunikan் (W. Sum.) ,zich door duwen ruimte maken".

In een aantal gevallen duidt de vorm met liquida aan de handeling door de nevenvorm zonder deze klank uitgedrukt steeds door of herhaaldelijk verrichten. Hier kan men spreken van frequentatieven, bv.

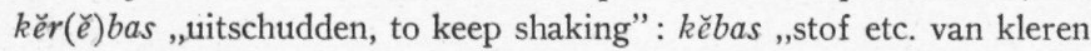
schudden”, ook kerribas: kibas; kĕrbat „enfolding in many folds": kěbat „omwikkelen”; kicu „oplichten, bedriegen”: kĕlicu (,freq. of kicu”, Wilkinson) ,bij kleine hoeveelheden ontfutselen”; tĕritek, ,dripping; dropping continually”: titek, titik ,druppel”: měnitik, ,in druppels vallen"; territi ,,continuous passage over a plank-bridge or narrow path" : titi ,smal voetpad, vonder”. In deze gevallen spreekt Wilkinson van frequentatieven; op te merken valt, dat territi geen werkwoord is. Het is intussen de vraag of men kĕrbas „blijven schudden” niet beter een duratief zou noemen, als men dergelijke termen bezigen wil. Een voortdurende handeling wordt in ieder geval uitgedrukt door měngerrumut ,to keep throbbing (as a boil or as the pulse)": kěmut „,kloppende beweging”; gerroncan ,to keep shaking”, Wilkinson spreekt van a freq. of goncain (,schudden"); op Java gĕrigit ,to keep biting, to gnaw” : gigit „bijten”; měnkĕlějep-an (Batav.) „to keep blinking”, $=$ terrkěja $p^{2}$. Er zijn ook gevallen van een voortdurende handeling 
uitgedrukt door een dergelijke langere vorm zonder dat er een kortere naast staat: měngĕlětin ,to keep tinkling”. In andere gevallen duidt de langere vorm aan: de handeling op (meer) intensieve wijze verrichten; een eigenschap in hoge, vrij hoge mate bezitten: kĕlědut „much creased, crumpled or wrinkled”: kĕdut „kreuk, rimpel, plooi etc.”; běrkědut ${ }^{2}=$ kĕlědut (Wilkinson) ; sělidik ,nauwkeurig onderzoeken, making a diligent search or enquiry": sidek „onderzoeken”. Vgl. daarbij gěpok ,mollig (kind)”: gělempok-gěmok ,zeer dik”. en trisyllaba zonder althans mij bekende disyllaba als měnděrobos ,een huis binnendringen”; mĕngĕrapu ,begerig grijpen naar”. Soms heeft de driesyllabige vorm betrekking op een meervoudig subject: batav. gĕlantuì „loshangend (van korte franjes)": gantun ,hangen”; kĕrabut „overzwermen, in menigte klimmen in"; kerrite ${ }^{2}$,to rattle or clatter, - of many small hard objects”; kĕrubut ,disorderly crowding; wild rush to one spot bij many people"; jërumbai ,bengelend, opgehangen hangend" (,of multiple objects such as the tassels of a fringe”) : jumbai ,,id., for single objects”. Of ook op een meervoudig object: kĕrobek ,picking out small pieces”; sĕlisek ,luizen".

Interessant zijn gevallen als de volgende: kĕdan ,recht uitgestrekt (arm), geveld (piek)": gělědan ,to extend the arms so as to inter-

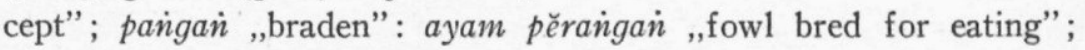
pěkat „lijmig, ingedikt, kleverig”: pĕrěkat „lijm, kleefstof, cement, mortel”; sisir „walking along an" island beach" ${ }^{1}$ ): sĕlisir ,walking along the inside edge of anything”; sirat "maas, netwerk" (měnyirat „knopen, een web weven (van spinnen), breien”) : sělirat ,,a complex but regular design in meshwork; reticulate; net-like (of spider's webs, lace, rigging etc.)" (Wilkinson), ,niet duidelijk in zijn delen te onderscheiden, zoals bv. de takelage van een schip, door elkaar gestrengeld, chaotisch”; sampok „tegen iets op-, aanlopen”: sĕrampok tungul „,man who is in everybody's way, clumsy person”; sandan ,iets dragen als een bandelier" : sěrandan் ,esv. bok of stut, bestaande uit twee stokken of houten, die van boven kruiselings zijn verbonden"; sandun „met de voet blijven haken aan”: sěrandun ,struikelen”; gosok „wrijven, schoonmaken door wrijven”: mĕngĕlosok „to keep rubbing, used specifically of the way clothes are wasked" (Wilkinson); kopak „bloemblad; een b. plukken; schillen”; kělopak „dunne bedekking of overtrek, kelkblad, ooglid en derg.”: mĕn்-gělopak „los raken (bast, schil)"; gigi ,tand": bĕr-gěrigi ,getand; zaagvormig;

1) Wilkinson, Malay-Engl. Dict. II, 414. 
als tanden uitstekend”: gĕligi ,klappertanden”; kĕbas ,verstijven, verlammen”, pari kĕbas = p. kĕlěbas ,sidderrog”; kĕmbun ,opgezet, opgeblazen; bol; bolle zijde van iets”: kělěmbuin „opzwellen (door lucht; blaar etc.)"; kopek ,van de buitenzijde, bv. schil van een vrucht iets afplukken”: kĕlopek ,afschilferen na zonnebrand”; koyak ,gescheurd (papier, kleren etc.)": kěloyak „loslaten van vel, schil, bast etc." (,much torn; to be in tatters; a freq. of koyak", Wilkinson); kupin ,korst over zweer": kĕrupin ,,idem, roofje”: kĕlupin ,plukkend aan roofje of zweer"; kontol ,kort, dik hangend voorwerp": kĕruntul ,hanging down stumpily and abundantly”; jamah ,betasten, aanraken": jĕramah ,seizure with tooth, nail, or claw; of a tiger or cat seizing its prey....; hitting out and clawing in a rush to get somewhere” (Wilkinson), ,flink aanpakken...., aanpakken van velen, bv. in een gevecht”; jahit "naaien”: jĕra(h)ït ,zich aan iets vasthechten”; pantin „verspreid”: pělantin „overal verspreid heenrollen; (eten) morsen”; sabut ,vezelige bast” : sěrabut „harig” ${ }^{1}$ ); sĕbu „opgevuld, gedempt, volgegooid”: sěrěbu „storten, werpen”; sankak „,belet, verhinderd”: sĕrainkak „een krans van latten of doorns om een boomstam om het inklimmen te beletten".

In deze gevallen heeft de langere vorm een andere betekenis, hoewel deze gemakkelijk in verband te brengen is met die van de kortere.

In een aantal gevallen vindt men de langere en kortere vorm naast elkaar zonder enig, althans opvallend of uit de opgaven op te maken, verschil; verschil in taalmilieu, geografische verbreiding etc. daargelaten; kekek ,giechelen” : gělekek; kicau ,sjilpen” etc. : gělicau ,id., to keep chirruping”; kupas ,schillen, pellen”: měněllupas, měngělupas „afschillen”; koncah „onstuimig (van de zee)”: kĕlocah; kompok ,groep personen": kĕlompok; tali kanjain „specious rogue”: $t$. kĕranjan் (Pen.); kĕkut „opkrullen”: kěrěkut „id.; kromtrekken”; kukut ,krom samengetrokken etc.”: kĕrukut „opkrullen etc.”; kuton்katan் „rusteloos, zenuwachtig”: kĕruton-kĕratan; pojok „hoek (van kamer etc.)": pělojok; (sa)pěmpap „,een handbreedte”: (sa)pĕlěmpap; pisañ ${ }^{2}$,gangplanken (schip)”: ked. pěrisan, pěpisan்; ponyok „kreu-

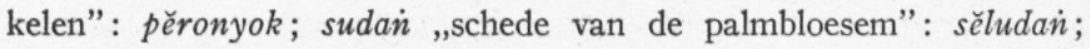
sampah „droog vuilnis”: sĕrampah; jĕlok „diep(e holte) van kommen etc." : ked. jĕrĕlok; etc. etc.

Er zijn ook enkele trisyllaba naast viersyllabige woorden: měngě-

1) Klinkert, Woordenboek s.v. noemt dit woord, het volgende en andere frequentatieven. Waarom? Aan een vezelige bast zitten toch ook verscheiden haren. 
latok ,blijven schudden (van onderkaak)”: gĕmĕlatok ,schudden of huiveren (koude, vrees, gelach), klappertanden”; měngělugut „huiveren, klappertanden": gěmělugut. Anderzijds komt wisseling van het volgende type voor: lětis "gejaagd, zenuwachtig, uitgelaten": gĕlětis ,hevig kronkelen, wriemelen” (indien het door Wilkinson tussen deze woorden gelegde verband inderdaad bestaat); lian-liut „van de ene zijde naar de andere zwaaiend": gělian-gěliut „curling this way and that ; swaying and twisting”; bĕr-lumur ,vuil": mĕngĕlomor ,vuil maken”; rayain „duizelig”: gĕrayan „wankelen”. Van interesse zijn ook doubletten, waarin behalve de hier bestudeerde uitbreiding vocaalwisseling voorkomt: $\min$. tambu, tambo ,tradities omtrent de oorsprong van de stam”: (Neg. Semb.) těromba „history embodied in a traditional saying". Voorts verdient het bestaan van gevallen als apit ,drukking tussen twee onverbonden oppervlakken”; kapit ,adjudant (die paarsgewijze hun chef of „middenman” insluiten)": jĕrapit „door drukking verbinden” (i.e. „to twist or squeeze several-objects into one").

Derhalve een zeer grote verscheidenheid van betekenissen. Vormen, die met recht frequentatieven mogen heten, zijn zeer in de minderheid. Naast talrijke trisyllaba zonder tweesyllabige nevenvormen zijn er vele woorden, die paarsgewijze optreden, maar met verschillende semantische verhoudingen; in ieder geval zo dat men meestal met geen mogelijkheid een „frequentatief” begrip zou kunnen vaststellen.

Ook in het Atjehs bestaan trisyllaba die er uitzien alsof ze een $l$ of $r$-infix bevatten: $t \ddot{o}$-bölanta' $=t \ddot{o}$-bölasat ,ergens verzeild geraakt”; gölincé ,uitgegleden"; een aantal onomatopeeën die met görö en körö aanvangen: göröbu' „dof geluid van een val” etc. etc., ook woorden, die zowel 2- als 3-syllabig worden opgegeven: $b(\ddot{o})$ lankah „esv. sabel”, g(ö)lawa ,(weg)smijten”.

In het Mentaway constateert Adriani ${ }^{1}$ ) het voorkomen van een $l, r$, $n$ - ,invoegsel”, onverschillig met welke klinker; ,de algemene betekenis.... is die van menigvuldigheid als de stam een werkwoord is, die van verkleining als hij een naamwoord is; deze betekenissen komen in kleine wijzigingen voor, maar zijn doorgaans in het afgeleide woord terug te vinden". Uit de gegeven voorbeelden blijkt dit mij niet steeds: bv. bulukbuk "draagmand voor het visnet”: bukbuk „pijlkoker”; gorosot „afdalen”: kosot ,idem”; guluguk „poel, plas”:

1) N. Adriani, Spraakk. schets van de taal der Mentawai-eilanden, Bijdr. 84, p. 68 . 
gukguk „plassen”; kalasa- $u$,een der dakbalken”: kasa-u ,dakspar”. Het Ngadju-Dajaks kent doubletten als kambohon: kalambohon „esv. kever”; kikir: karikir ,het bij elkaar geschraapt zijn”; sankahut: salankahut „verwirrt, vertoddert”; daarnaast trisyllaba van het type

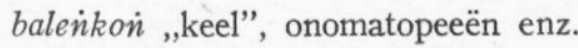

In het Balisch bestaat een menigte trisyllaba, ,die in zoverre niet meer oorspronkelijk kunnen heten, dat ze door tussenvoeging van de lettergrepen $\breve{e l}$ of $\breve{e r}$ van tweesyllabige gevormd zijn....": tĕlusuk. „doorboren (van de neus van een trekos)": tusuk ,doorboren”; cĕrońcon „esv. trechter”: concon „,een gat delven”; cĕlapat „,aanhoudend voor iemand heenlopen": capat ,aanspreken" ${ }^{1}$ ).

Interessant is ook het Bare'e: Adriani leert ${ }^{2}$ ), dat de ,infixen" $l$ y $r n$, waaraan iedere klinker kan voorafgaan, en waarvan $b$ en $r$ met voorafgaande $a$ het meest voorkomen, identiek zijn - een punt, waarop ik hier niet inga, al nemen we nota van de gelijkwaardigheid -, en , in het algemeen frequentatieve, meervoudige of verkleinende betekenis” hebben. „Dat men dit invoegsel aanwezig acht, waar het naar de hier gevolgde beschouwing niet voorhanden is, toont aan dat het in het bewustzijn der taal nog geheel levend is". Met deze zin zal Adriani wel bedoelen, dat het taalbewustzijn het ook abstraheert, wanneer hij het niet als frequentatief-vormend infix erkent, - en dus niet aanwezig acht. Uit zijn woordenboek ${ }^{3}$ ) blijkt, dat hij enkele malen van frequentatief spreekt, elders een bepaald woord tekent als ,met - $a r$ - van..$\left.{ }^{4}\right)$, vaak ook iedere toevoeging achterwege laat. Ook het Bare'e kent onomatopeeën etc. (bv. perede ,luid, knetterend geluid geven"), plantnamen, woorden voor gebruiksvoorwerpen, instrumenten, muziekinstrumenten van de hier bestudeerde driesyllabige vorm. Daarnaast een aantal, eveneens, naar het schijnt, niet-analyseerbare trisyllaba: balumba ,grote golf”; talondo „grote en hoge waterval" ${ }^{5}$ ). Daarnaast bestaat er een vrij groot aantal woorden met ar naast woorden er zonder. En dat wel: a) zonder, althans in het woordenboek tot uiting gebracht, verschil in betekenis : so' $u$,afrukken" ${ }^{6}$ ): saro'u (,frequent. vorm”, Adriani); sa'u ,aan een haak ophangen”: sara'u; tobi ,diepe plaats in het water": tarobi; wenciki „bijten":

1) R. van Eck, Handleiding Balin. taal, § 63 .

2) N. Adriani, Spraakkunst Bare'e, § 185.

3) N. Adriani, Bare'e-Nederlandsch Woordenboek, 1928.

4) Bv. tarampa: tampe, p. 818 .

5) balaya „deining” (priestertaal balayani „golven”) bij baya „niet diepgaande insnijding in terrein"?

6) Ik geef slechts de grondwoorden, niet de afleidingen op. 
walenciki; b) met een meer speciale betekenis van het langere woord: bainko ,overhands gooien”: bareinko „met stok of steen werpen naar vruchten of dieren”; bente (intr.) „opengaan”: bulente „ontplooid”; $k a b a$,,bedeksel”: karaba (,inf. -ar-", Adriani) ,jakje, vrouwenbaadje”; sampe „over iets heen hangen, zodat het steunt en tevens afhangt": salampe ,zo over één schouder hangen”; c) tussen beide is een verschil in nuance, in spraakgebruik etc. ${ }^{1}$ ) : bence ,vertrokken (gezicht, lippen)": belence ,omgekruld (snede van een werktuig, lippen)”; megoli ,omlopen, overlijden”: men்-galoli alleen „overlijden”; $k u k u$,afgrazen”: karuku ,afbijten, afknabbelen”; pita $^{2}$,,kledderig, vochtig”: purita „kleverig”, soso „kappen (bladeren etc.)”: saroso „,met een mes hakken aan dorens, bladeren etc.”; tribubu ,put": talimbubu ,wel”; d) de langere vorm is een zelfstandigheid, de kortere niet: bólan்i ,,(de nacht over) waken”; balólanii eig. ,bewaker”, „een instrument om een hond vast te houden”; gango "grijpen”: garaingo ,grijper”, d.i. „,krokodil” 2); guga „,spoelen” : garuga ,bezinksel”; keke ,uithollen”: kaleke ,holle weg”; koka ,samenkomen": karoka ,plaats waar neusen mondholte samenkomen"; sapu ,bedekken": salaputi ,het vlies dat de darmen bijeenhoudt"; e) de langere vorm is een werkwoord: kijo ,geluid van een gil": kirijo ,gillen”; kompe ,ingevallen (buik)”: kolompe ,zijn buik intrekken”; sepa „vertakking”: sarepa „(zich) vertakken”; tobo ,puntig, spits” (adj.) : tarobo ,mikken (zonder nauwkeurigheid)”; f) ander verschil in woordsoort etc.: gaga ,te zeer": galaga ,vlug in spreken, bewegingen etc.”; soba ,afgehakt": soroba „plotseling”; sobo „slikken”: sarobo „slurpen”; seǹko „krom”: (dial.) seinko, sareinko ,wiedmes”; sopo „klaar”: saropo „takken afhakken”; m.i. ook bali ,tegendeel”: balali (,,frequent." Adriani) ,verdraaien”; g) soms heeft de langere vorm een meer intensieve betekenis: tente „schudden”: tarente ,op-, uitschudden”; wenta ,omdraaien”: walenta „,in elkaar gedraaid en verward"; h) soms een frequentatieve: geinga „,iets uit elkaar werken”: garenga „,begrabbelen”; genge „omgewoeld": galenge ,,aldoor heen en weer gaan, zich onrustig gedragen"; tarepe (: napoe tepe) „,bengelen”; walebu, wulebu ,spartelen, stuiptrekken”: webu ,besprenkelen, heen en weer zwaaien"; ook kapi „klapwieken”: galapi „,met de armen of vlerken zwaaien”? Het aantal woorden met een frequentatief begrip vormt een kleine minderheid. En ook Adriani ${ }^{3}$ ) moet althans het voorkomen van de meer intensieve

1) Vgl. ook napoe tampa, „grens”: tarampa „rand, zoom”.

2) Vgl. ook balombonia ,rondprater".

3) Spraakkunst, t.a.p. 
betekenis van een langere vorm t.o.v. de kortere toegeven: „Het onderscheid tussen wewe en walewe is dit, dat al in walewe de betekenis versterkt, intensiveert, vermenigvuldigt: tewewe is ,omwikkeld”, tazealewe is ,om- en omgewikkeld”". Van een ,verkleinende betekenis" mag men m.i. niet spreken in gevallen als taroto: ,klein-, fijn hakken, in stukjes hakken": toto "hakken (met zwaard of mes)"; deze betekenis is of die van een herhaalde of die van een sterkere handeling. Aan de meeste overige door Adriani in zijn Spraakkunst geciteerde voorbeelden is het frequentatieve begrip, althans voor mij, moeilijk of niet te constateren. Wat het „frequentatieve” is in kalama ,handvat van een zwaard, dat de vorm heeft van een geopende krokodillenbek" tgr. in Minah. talen kama ,hand" is mij niet duidelijk. Gaan we de Bare'e woordschat na, dan blijken er verscheiden uitdrukkingen te zijn die, hetzij met dezelfde, hetzij met een na-verwante of overgedragen betekenis, inwendig een syllabe meer hebben dan hun etymologische aequivalenten in verwante talen: bar. galengo ,in een fakkel roeren”: mak. gengo "schudden”; bar. kariki (amp. kiriki) ,oksel”: westtor. keke, kbat. kiki; bar. piliko ,geschreeuw van apen”: mal. pikau ,geschreeuw”; talombo „grote staatsielans": mal. tumbak "grote lans".

In deze laatste groep kan ik niet anders zien dan Streckformen, evenals in de groep a (zie boven); bij de groepen b en c is tussen de doubletten, eveneens in oorsprong Streckform naast niet-uitgebreide vorm, een verschil in gebruik of betekenis ontstaan; bij g en $\mathrm{h}$ is dit verschil zodanig, dat de handeling versterkt of herhaaldelijk wordt uitgedrukt; bij d, e, $\mathrm{f}$ behoren de woorden in een verschillende woordkategorie ${ }^{1}$ ). Voegen we er nog aan toe, dat naast setu, het aanwijzend voornaamwoord van de $2 \mathrm{e}$ (en 3e) persoon voorkomt saretu, dat ,een meervoudige, meer algemene betekenis heeft, maar geen regelmatige meervoudsvorm is; het veralgemeent slechts de betekenis" ${ }^{2}$ ).

Op de benaming „,frequentatief infix”, die ook Esser ${ }^{3}$ ) bezigt, is voor het Bare'e dus wel wat af te dingen. In het Mori ,worden geen nieuwe vormen meer (ermee) gemaakt"; men vindt salampe, sanampe „sjerp”, siloli „fluit”: mal. s(ĕr)ulin; ; mompalewesi ,omwinden” : pewe.

a) Ik laat enige gevallen terzijde, waar ondanks het door Adriani gelegde verband, de etymologische samenhang mij niet duidelijk is, bv. gosu „(door)buigende" : gorosu „tussen dik en mager"; is karapu "met de volle hand grijpen" uit "geheel overdekken": kapu ,overdekken"?

2) Adriani, Spraakkunst, § 185.

3) S. J. Esser, Klank- en vormleer van het Morisch, p. 354 , § 371. 
„Het infix -al-, -ar-, dat ook voorkomt in de vormen $-a j-,-\breve{e} l-\ldots$. heeft in het algemeen een frequentatieve en een diminutieve beteekenis", vangen Schwarz-Adriani ${ }^{1}$ ) hun opmerkingen betreffende de ons interesserende woorden aan. Ook hier weer de stilzwijgende veronderstelling van identiteit van de niet minder dan 11 varianten van het woorduitbreidende element en de overtuiging, dat $a l$ en $a r$, de meest frequente en uit langer bestudeerde Archipeltalen meest bekende vormen, de eigenlijke gedaante of grondgedaanten van dit element zouden zijn ${ }^{2}$ ). Even verder lezen we, dat ,in het algemeen de ,infixen" met $l$ frequentatief zijn en die met $r$ diminutief," wat, strikt genomen, niet geheel klopt met wat dezelfde auteurs hogerop opmerkten $\left.{ }^{2}\right)$; nl. dat $a l$ en $a r$ geheel identiek zouden zijn en frequentatieve betekenis hebben. Maar genoemde auteurs hebben toch ook ingezien, dat het ,soms” niet te zeggen is, welke betekenis aan het infix moet worden toegekend, ,omdat de beteekenis van het woord waarin het is gevoegd niet frequentatief of diminutief is, vergeleken met die van het grondwoord". Ik verwijs naar hun voorbeelden en merk op, dat mij ,,verkleinende betekenis" van al in kalasin ,pink" niet bewezen lijkt, noch minder de afleiding van kasin, ,dat waarschijnlijk identiek zou zijn met mal. kasih, bar. asi in de bet. ,arm, gering, deerniswaardig" ": het woord voor ,pink”: mal. kalinkin, gajo klěnkin, mak. kaninkin, vertoont in het Bare'e en naverwanten gelijkenis met tont. kalasin, maar daar staat de $l$ na de $s$ : bar. kasili, par. konjili, boengk. kulisi: m.i. een ,primitief” trisyllabum van variabele gedaante. Volgens Schwarz ${ }^{3}$ ) is kalĕk kĕs „,een bepaald soort gestreepte tor" ahw. „omwonden”: kĕ kěs ,omwinden”, en het woord een frequentatief, een term, die ik alleen van werkwoordsvormen zou willen bezigen. Het woord kěrětěn ,stijf worden” bij *kĕtěn , strak, stijf” behoeft geen „frequentatief” te zijn. Lasvormen zonder meer schijnen mij o.a. te zijn : kĕrěreur ,duister, troebel” : kĕzenr ,troebel”, kilipus, ,ingetrokken”: $k i p u t$,samengetrokken” e.a. Soms is de langere vorm duidelijk een sterkere uitdrukking voor het begrip: těki', těkis, těkic „,klein”: těrěki etc. „zeer klein”; pě pěs „uitslaan, -slingeren”: palě pĕs „,de armen links en rechts flink uitslaande"; $k a^{\prime}$ is ,gebrek" (Schwarz): kura' is ,totaal gebrek hebben aan iets"; vgl. ook sorombuak ,met kracht uitkomen”. Andere duiden een wijze van zich voor

1) J. Alb. T. Schwarz-N. Adriani, Hoofdstukken uit de spraakkunst van het Tontemboansch, p. 185.

2) Ibidem, p. 37.

3) J. Alb. T. Schwarz, Tontemboansch-Nederlandsch Woordenboek, s.v. 
te doen etc. aan: kuritic, kuricil „met krullend haar zijn”, kuru'tus ,ineengedoken". Weer andere een modificatie van het begrip: sisip „tussen iets steken": solisip, ,in het geheim idem, zich indringen tussen personen". Woorden die een herhaalde houding aangeven zijn er inderdaad veel bij: wa'kěs ,datgene waarmee men iets vastbindt": wara'kis ,vele malen winden van een touw om iets”. Ook hier ontbreken de trisyllaba met $r$ etc. voor termen voor planten, dieren, voorwerpen, lichaamsdelen, gebreken, muziekinstrumenten, alsmede onomatopeeën etc. niet.

In het Bolaang-Mongondow ${ }^{1}$ ) zijn, volgens den auteur der spraakkunst, de ,infixen” al ol ul ar oy or on, die hij als één groep beschouwt, ,meermalen geheel vergroeid met het oorspronkelijk grondwoord, waardoor de beteekenis soms moeilijk is vast te stellen". Juister ware: $a l$ etc. maken deel uit van niet-analyseerbare trisyllaba. Weer : woorden voor planten, dieren ${ }^{2}$ ), gebruiksvoorwerpen; onomatopeeën etc., woorden waarmee te kennen wordt gegeven: „zooiets doen of zijn als wat het grondwoord zegt, de handeling doet wel een beetje aan die van het grondwoord denken, maar is toch iets anders" ${ }^{3}$ ). Ondanks dit alles hebben deze woorden voor Dunnebier ,in het algemeen een frequentatieve of meervoudige en soms een verkleinende beteekenis". Hoe weinig hij hier van de feiten uitgaat, blijkt bv. uit zijn opmerking over on ${ }^{4}$ ): ,Ook aan -on- meenen we frequentatieve en verkleinende kracht te mogen toekennen, al kunnen we dit slechts met een paar voorbeelden staven"; waaruit deze kracht bij die voorbeelden dan blijkt, zegt hij er niet bij : -on- in gonugur ,het gebulder van de wind" kan (gezien gugur ,schudden, beven, àls ze samen behoren) frequentatieve kracht hebben, maar ook intensieve, en het beste is dan te zeggen, dat het een primitief-expressieve uitbreidende syllabe is ${ }^{5}$ ).

Hoewel Adriani ${ }^{6}$ ) van oordeel is, dat in het Sangirees al in de betekenis van het grondwoord allerlei wijzigingen, doorgaans een meervoudige of frequentatieve betekenis aanbrengt, wil het mij voorkomen, dat er in de door hem geciteerde voorbeelden meestal eerder sprake is van Streckformen met in de meeste gevallen gedifferen-

1) W. Dunnebier, Spraakkunst van het Bolaang-Mongondowsch, Bijdragen 85 en 86 , speciaal 85 , p. 574 vlg.; voorbeelden p. $575-582$.

2) Hierbij behoort niet garudas ,een fabelachtige vogel", Dunnebier, p. 579.

3) Dunnebier, p. 579.

4) Dunnebier, o.c., p. 581 .

5) Interessant is, als het woord inderdaad zo luidt, tonomujus „wijsvinger".

6) N. Adriani, Sangireesche Spraakkunst, p. $151 \mathrm{vlg}$. 
tieerde betekenis : kambị: manalambị „,enteren”; sazuȟ̌ ,uitstrooien, zaaien”: saliawuhĕs ,vallen en verstrooien”; toka „twee voorwerpen tegen elkaar slaan”: taloka ,in de handen klappen”; běka „,gedeelte”, balěka „kaf”.

In het Iloko schijnen ar, al (li, ri) in enige gevallen voorhanden te zijn $\left.^{1}\right)$ : pinak „helft”: palinaak; pinas ,een vlakke plaats”: paranas „,vlakte”.

De gangbare, al of niet uitgesproken, opvatting omtrent de hier vermelde woorden is dus deze: zij zijn gevormd met een ,infix" $r$ of $l$, al of niet plus vocaal; dit infix vormt een frequentatief, ook wel een intensief of meervoud ${ }^{2}$ ); dit infix is vaak nog levend, vaak verstard; en men tracht, m.i. met vrij gering succes, van een aantal woorden aan te tonen, dat zij oorspronkelijk of eigenlijk ,frequentatieven” zijn geweest of zijn, of wel, men laat dit na. Onbewust staat men hierbij, op het standpunt, dat een toestand met infix oorspronkelijker is of wel moet zijn, dat het meer uitgebreide systeem, de grotere vormrijkdom ouder en oorspronkelijker is. Een standpunt, dat nu bijkans een halve eeuw verouderd mag heten. $\mathrm{Al}$ mag men niet ontkennen, dat een dergelijke ontwikkeling in andere gevallen de juiste zal zijn, voor dit geval lijkt zij mij onwaarschijnlijk. Ten eerste is het zeer grote aantal woorden waarin we met geen mogelijkheid kunnen aantonen, dat $l r$ etc. infix zijn of geweest zijn opvallend; ten tweede is het zeer vaak niet doenlijk om ,frequentatieve etc. betekenis" aan te tonen; ten derde is er in talen, waar ons overzicht een bont beeld gaf (het Maleis bv.) niet wel een semantische draad door de verschillende ,betekenissen” der langere woorden ten opzichte van de disyllaba die er naast voorkomen te trekken.

Ik zou de stelling willen opwerpen, dat we hier voor ons hebben $1^{0}$ een groep niet-analyseerbare trisyllaba, die we laten rusten ${ }^{3}$ ); $2^{0}$ een groep onomatopeeën, Lautbilder, klanksymbolische woorden, waarin de $l r$ etc. een zekere rol spelen in het klankbeeld van het woord in zijn geheel ${ }^{4}$ ), in verband met de andere klanken van het woord een primitieve functie hebben; $3^{0}$ lasvormen in de strikte zin des woords, die aantoonbaar zijn voorzover er kortere woorden

1) H. W. Williams, Grammatische Skizze der Ilocano-Sprache, Diss. München 1904 , p. 40.

2) Zie bv. R. A. Kern, Bijdragen 102, p. 299 en p. 83 vlg.

3) De grens tussen deze woorden en disyllaba met postconsonantische $r, l$, $y$, $w$ is niet te trekken.

$\left.{ }^{4}\right) \mathrm{Bij}$ met gĕrĕ aanvangende woorden is rekening te houden met svarabhakti (naast gĕr + cons.).

D1. 102. 
zonder of nagenoeg zonder betekenisverschil naast staan, maar zich naar alle waarschijnlijkheid ook bevinden onder die trisyllaba die geen kortere nevenvorm hebben. Het lijkt mij nu verder aannemelijk, dat in verscheiden gevallen het bestaan van doubletten, een langer naast een korter woord, semantische differentiatie met zich meegebracht heeft, - een bekend verschijnsel ${ }^{1}$ ). In het Middelhoogduits waren bv. Knabe en Knappe volkomen synonieme doubletten, die beide de moderne betekenissen konden uitdrukken; thans betekent het eerste „,jongen”, het tweede „schildknaap, gezel”; pas in de Nieuwhoogduitse periode zijn Jungfrau en Jungfer, Reiter en Ritter semantisch gedifferentieerd. Vaak zijn verschillende pluraalvormen zich in betekenis van elkaar gaan onderscheiden: Bande „boekdelen”: Bänder „linten, banden”; eng. brothers (in eigenlijke zin): brethren (gewoonlijk overdrachtelijk); ned. tafels: tafelen; vaders: vaderen etc. Dergelijke differentiatie treft men ook aan tussen langere en kortere vorm van oorspronkelijk hetzelfde woord: eng. history: story; jav. kabudidayan ,culture(s)": kabudayan „cultuur”; en om een op een leenwoord gebouwde Streckform als voorbeeld te nemen : mal. sěrapah is ,bezweringsformule, vervloeking”; het is uit sĕrpa ontstaan (anaptyxe), dat „vloek” en „zegen” betekent (<skt. śāpa- „vloek”).

Daarbij is het, neem ik verder aan, gebeurd, dat in dezelfde taal meer dan een langer woord in een bepaalde „betekeniskategorie”, ja, „woordsoortkategorie" kwam, terwijl ook de kortere woorden in eenzelfde kategorie lagen. Hier kon voor het taalgevoel het element, dat in het langere woord meer is, als drager van een bepaalde functie (het brengen in de andere kategorie) verschijnen ${ }^{2}$ ). Dit is op verschillende wijze gebeurd en zo heeft het element in dit groepje woorden deze, in dat groepje gene ,betekenis”. Een deel dezer functies, "betekenissen" is geworden het aanduiden van een meer intensieve of van een herhaalde handeling. En op een gedeelte van het Indonesische gebied, speciaal in het Javaans en het Soendaas heeft deze functie een aanzienlijke uitbreiding ondergaan, zonder twijfel onder invloed van de omstandigheid, dat de liquidae een bijzondere geschiktheid bezitten om woorden te helpen vormen, die een herhaalde handeling uitdrukken. Het is echter een onjuiste veronderstelling, dat die klanken in die woorden, althans in al die woorden, in een taal

1) Waarover bv. H. Paul, Prinzipien der Sprachgeschichte ${ }^{5}$, § 176 vlg. Vgl. ook Bijdragen, 100, p. 149 vlg.

2) Anderzijds zijn vele oorspronkelijke Streckformen verstard als ned. slabakken. 
van meet af aan die betekenis moeten hebben gehad, dat ,in die klanken een frequentatieve of meervoudige kracht ligt". Neem de Nederlandse frequentatieven als trappelen, kittelen, snateren etc. In het kort is hun geschiedenis deze: uitgangspunt zijn de vele werkwoorden die afgeleid zijn van substantieven op el of er: zadel: zadelen; honger: hongeren; waarvan een aantal kon worden opgevat als directe afleidingen van werkwoorden: druppelen van druppen; klapperen van klappen etc. Dit geschied zijnde, ontstond er een suffix (dwz. abstraheerde het taalbewustzijn de klanken el resp. er als suffix), waarmee verba konden worden gevormd. Dit suffix werd productief : er ontstonden nieuwe woorden, die het bevatten : snuffelen naast snuiven; blikkeren naast blikken. $\mathrm{Nu}$ had een aantal met -elof -er- gevormde verba een frequentatieve betekenis, of men kon althans de vorm als zodanig opvatten: kwispelen, waaieren, druppelen, etc. Daardoor werd voor het taalgevoel die frequentatieve betekenis inhaerent aan het suffix. We zien nu, dat bij de later ontstane vormen de frequentatief-functie van het suffix overheerst. Tenslotte kwam er een groep niet van werkwoorden zonder -el- of -er- afgeleide werkwoorden op, die ten dele onomatopoëtisch zijn : rammelen, bulderen, dompelen, fluisteren, etc. ${ }^{1}$ ). Voor een groep Griekse woorden die snelle bewegingen aanduiden, zoals $\tau \varrho \circ \chi \alpha \lambda i \zeta \varepsilon \iota v$,rollen, wentelen”

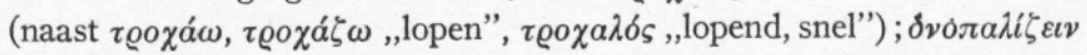

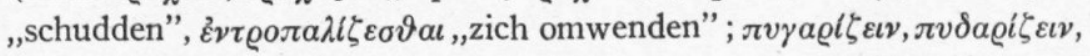
$\pi v \nu \delta \alpha \lambda \zeta \zeta \varepsilon v$,huppelen, dansen” (bij $\pi v \gamma \eta$,,achterste”) zoekt men het uitgangspunt in een woord als het van $\sigma \tau \varrho o \varphi \alpha ́ \lambda \iota \gamma \xi$,werveling, draaiing” afgeleide $\sigma \tau \varrho o \varphi \alpha \lambda i \zeta \varepsilon \iota \nu$,draaien”; trouwens er was nog

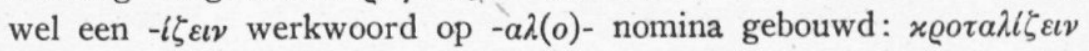

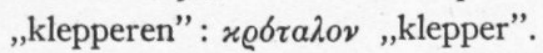

De in het Javaans en vooral de in het Soendaas bereikte toestand, waarin ons element in vele woorden geheel affix is geworden en als zodanig productief, is derhalve m.i. de jongste fase. $\mathrm{Er}$ is geen enkele reden om dat wat in de taal der meeste sprekers of der hoogste cultuur bestaat voor het meest oorspronkelijk te houden, evenmin om nog te geloven in de mystieke eigenschappen van een ,sleuteltaal”. Trouwens, al heeft onze kennis van de oudere perioden van het Javaans lacunes, al mogen we bv. de taal van parwa's en kakawins geenszins identificeren met de gesproken taal, wel wijzen de gegevens er op, dat de hier

1) Ook hier vinden we soms afwisseling van $l$ en $r$ : wandelen, mned. wanderen, du. wandeln, wandern etc. 
bestudeerde liquidae minder aan een bepaalde vocaal gebonden waren, dat het element vocaal + liquida minder vaak systematisch aan een bepaalde functie gebonden moet zijn geweest, dus zeker minder het karakter van een infix had.

Daarnaast (zonder dat er grenzen te fixeren zijn) zijn bepaalde

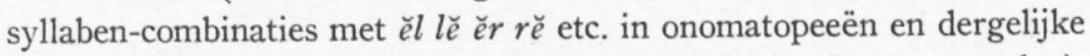
productief geworden: děrě , gělě, gěmělĕ (aan het begin van woorden).

Tenslotte nog een paar kleine opmerkingen. De Bare'e „infixen” l y $r n$ met voorafgaande klinker zijn volgens Adriani ,identiek” ${ }^{1}$ ), en Esser ${ }^{2}$ ) noemt als voorbeeld van het „frequentatieve infix -al-ar-", „dat in tal van vormen kan voorkomen” mor. toniso ,vinger”, oorspr. ,wijsvinger”: tiso, vgl. bar. tanuju ,wijsvinger”: tuju ,(aan) wijzen". Deze wijze zich uit te drukken lijkt mij gevaarlijk: in plaats van identiek zou ik eerder ,gelijkwaardig", of, nog liever en voorzichtiger, „van gelijke aard” willen lezen. En dat een „wijsvinger” een „frequentatief begrip” zou zijn, iets wat men zich door de ,identiteit” van an en al ěl (cf. mal. tělunjuk ,wijsvinger”) aan te nemen suggereert en waarvoor men dan wel deze verklaring vindt: de wijsvinger is dat waarmee men herhaaldelijk, steeds wijst, is geenszins evident. Er zijn immers vele woorden die aanduiden ,iets waarmee men een bepaalde handeling verricht", die geen gedachte aan frequentie of frequentatieven opwekken, bv. de p̌e + nas.-woorden, type mal. pěmikat (bij pikat) „lokvogel”. Bovendien bestaat de mogelijkheid, dat het grondwoord oorspronkelijk zowel ,wijzen" als ,wijsvinger" betekende (zo in het Sa'a, Melan., het verwante 'usu') en dat zich aan de uitgebreide variant de laatste betekenis vastzette.

Een bedenkelijk gevolg van het vertrouwen in deze „identiteit” is het m.i. ook, dat men op grond daarvan klankovergangen opstelt. Schwarz-Adriani ${ }^{3}$ ) achten het waarschijnlijk, dat in het Tontemboan $y$ uit $l$ ontstaan is en wel op grond van enkele voorbeelden, waar , $r$ met $y$ afwisselt”, bv. Mañayoyon voor Manaroyon (,naam van een kolk in een rivier"), en voorts, omdat ,het frequentatief-infix -arof -al-" soms de vorm -ay- heeft, bv. kayoikkon ,klappertanden”. Een enkele eigennaam en primitieve, onderling variabele woorduitbreidingselementen: daaruit mag men m.i. geen klankregels abstraheren.

1) N. Adriani, Spr. Bare'e, § 185.

2) S. J. Esser, Klank- en vormleer van het Morisch, p. 354.

3) J. Alb. T. Schwarz, N. Adriani etc., Hoofdstukken uit de Spraakkunst van het Tontemboansch, p. 38. 


\section{A D DEN D A.}

p. 388, 2e alinea. Bij tahulan toevoegen : vgl. pon. bis. bat. e.a. tulan „bọt, been”.

p. 392 , r. 24 vlg. Een aardig geval van uitbreiding door anaptyxe, tegelijk adaptatie van het woord aan zintuigelijke indrukken, die de zaak maakt: jav. sorok ,houten schoffel, schuiflat, harkje (voor geld) etc.”: slorok (gew.) ,schuif-, sluitbalk”: soend. solorok, sorolok ,(de grendel) schuiven voor iets": mad. sělorokån ,schuif”.

p. 398 , r. 10 v. o. „Een treffend voorbeeld is in het Katwijksch het affectieve verachtelijke kleváeneze voor klaeuwe (,handen”) in een zin als : „Die vent kon geniens 'n riem in z'n klevaeneze hauwe, lae-staen 'n paer slaege roeije"'” (G. S. Overdiep, Stilistische Grammatica van het Moderne Nederlandsch, 1937, p. 200).

p. 413, r. 24 toevoegen: guměntyà் (R. Lawe 7, 79): gěntan் ,alarm slaan".

p. 414. In de Rangga Lawe komen relatief veel dergelijke trisyllaba voor : 4, 21 kasulirin; 4, 80 caracap (K.B.W. I, p. 589); 4, 89 asarawayan (vgl. K.B.W. III, p. 85 suraweyan); 4, 89 aparantunan (vgl. 6, 11); 4, 102 gineregel; 5,2 asarakat (K.B.W. III, p. 70) ; 6, 26 kasolondohan (K.B.W. III, p. 242) ; 8, 36 ginoromyok (K.B.W. II, p. 111 s.v. koromyok) ; 11, 14 akarasak; 11, 20; 67 analasar; 11, 27 atrězenhan; 11, 47 mulinà்; 11, 143 kasuririn; 11, 161 akurambeyan; 11, 189 kurawitan (K.B.W. II, p. 256 akulawiran); 11, 230 akulesedan ; 12, 7 sinalanisain, e.a.

p. 414 , r. 24. Meervoud van onderwerp: taratap, pin t. (R.L. 4, 2; 54); tatap $=$ tumpak (K.B.W. IV, p. 600; 664).

p. $414,1 \mathrm{e}$ alinea. Toevoegen : sělěksěk (Sor. 3,108 ), ,in groten getale aandringen op”: sěksĕk ,dicht op elkaar, dringen”.

p. 414 onder, toevoegen : een onomatopee als krěsěk, krosok; nevenvorm kurasak (K.B.W. II, p. 91).

p. 417 , onder. Over de expressieve waarde van woorden die met $s l$ etc. aanvangen in het Nederlands (slungel, sloeri, slons, slempen, slet) zie thans ook A. W. de Groot, Scientia, Handboek voor Wet., Kunst en Gesch., I (1938), p. 264 vlg. en dez., Structural linguistics and phonetic law, Arch. Néerl. de Phon. Exp. 17 (1941), p. 104 vlg. 
p. 419 , r. 6 vlgg. lat. gibbus „bochel”, op inscripties ook glibbus; fitilla ,esv. offerkoek”, in handschriften ook fritilla, firitilla; cacerro „krassen” ook cracerro.

p. 422, 2e alinea, r. 6. Toevoegen: In Middeljavaanse teksten komen de pati( $\dot{n})$-verbindingen vaker voor dan in de Oudjavaanse in strikte zin: frequent is pati $(\dot{n})$ samburat ,uiteenstuiven" (Kid. Pam. 3, 55; Sor. 3, 40, Naw. p. 32 e.a.); daarnaast ook samburat alleen (bv. R.L. 7,110 ; 11, 93; sumamburat, Kid. Pam. 4, 80; 85); patin kuramban (R.L. 6,$18 ; 11,62)$,overal ronddobberen (van vaartuigen)": kambain (vgl. K.B.W. II, p. 111); pin p(ě)lěcut ,overal ontploffen” (bĕdil, R.L. 11, 169; H. Wij. 2, 78a); pin purinkan (mati, R.L. 7, 58, vgl. K.B.W. IV, p. 142); pati blĕnton் (Naw. p. 32, 27) ,overal vol vlekken zijn”; daarnaast pì balěntòn (Sud. 1, 12, vgl. K.B.W. IV, p. 861 s.v. běnton்); pin srĕmuk ,snikken” (R.L. 12, 1, vgl. sěnuk K.B.W. IV, p. 404); pri celeret ,door de lucht vliegen” (Çri T. 5, 92), e.a. Er zijn ook enkele gevallen van pati voor een disyllabicum: pati purug, $p$. purug $^{2}$ (Kid. Pam. 5, 47; 51; Kd. Sunda, 2, 149; vgl. K.B.W. IV, p. $130=$ p. babar $) ;$ p. gabag ,als een blinde tasten”.

p. 429, 2e alinea. De Heer L. Metżemaekers maakt mij op nog enige Atjehse gevallen attent: gö’ò $b$ : görö'ò ,een boer laten”; göhén: göröhén „grijnzen”; göpōh: göröpōh „,vierkant hok van bamboe of hout"; gösò’: görösò' „schuren, polijsten”; gantoïh, göntòh : gölantòh „stotend, gestoten"; guncan: göruncan „schudden, heen en weer bewegen"; gitê": gölitê" "pink".

Op p. 421 en 435 is om typografische redenen $\breve{e}^{s}$ (naast $i$ etc.) gedrukt. 